\title{
GLOBALIZATION, WAGE SHARES AND INCOME DISTRIBUTION IN TURKEY
}

\author{
M.A. Thesis by \\ Cem OYVAT, B.Sc. \\ 412061007
}

Date of submission : 5 May 2008

Date of defence examination: 9 June 2008

\begin{abstract}
Supervisor (Chairman): Assistant Prof. Dr. İpek İlkkaracan AJAS
Members of the Examining Committee Assistant Prof. Dr. Mehtap

HISARCIKLILAR (ITTÜ)

Prof.Dr. Nurhan YENTÜRK (BÜ)
\end{abstract}

JUNE 2008 


\title{
İSTANBUL TEKNIK ÜNIVERSITESİ $\star$ SOSYAL BİLIMLER ENSTITTÜSÜ
}

\author{
KÜRESELLEŞME，TÜRKIYY'DEKİ ÜCRET PAYLARI VE \\ GELİR DAĞILIMI
}

\author{
YÜKSEK LİSANS TEZI \\ Müh. Cem OYVAT \\ 412061007
}

Tezin Enstitüye Verildiği Tarih : 5 Mayıs 2008
Tezin Savunulduğu Tarih : 9 Haziran 2008

Tez Danışmanı : $\quad$ Yrd. Doç. Dr. İpek İlkkaracan AJAS

Diğer Jüri Üyeleri: $\quad$ Yrd. Doç. Dr. Mehtap HíSARCIKLILAR (íTü)

Prof.Dr. Nurhan YENTÜRK (BÜ)

HAZİRAN 2008 


\section{PREFACE}

It is clear that the Turkish economy has experienced a great change in the post 1980 period. The Turkish economy has become more open to the impact of globalization and the globalization affected each income group in a different way. In this study, the impact of globalization on the individual and functional income distribution is examined. The study mainly focuses on the relation between trade flows and income inequality. The changes in income inequality are analysed by using different income distribution data.

I would like to express my gratefulness to my supervisor Assist. Prof. Ípek İlkkaracan for her guidance and great motivation that she has given during every phase of my thesis. Also, I would like to thank Assist. Prof. Mehtap Hisarciklilar for her helpful suggestions and comments for the empirical analysis. Finally, I would like to express my special thanks to my family and my friends for their support and help. 


\section{CONTENTS}

TABLE LIST

FIGURE LIST vii

ÖZET viii

SUMMARY ix

1.INTRODUCTION 1

2. AN OVERVIEW OF THE TURKISH ECONOMY 3

2.1. Trade and capital account liberalization in the post 1980 era 3

2.2. An overview of the changes in inequality and labor markets $\quad 7$

3. AN OVERVIEW OF IMPACT OF GLOBALIZATION 11 ON INEQUALITY

3.1. Setting the theoretical framework: The effects of 11 globalization on the distribution of income

3.2. Distributional Effects of Globalization: Empirical Studies

3. 2. a. Income Distribution Across and Within Countries 17

3. 2. b. Studies on Inequality in Turkey 24

4. AN ANALYSIS OF INCOME INEQUALITY INDICATORS 30

IN THE POST 1980 PERIOD IN TURKEY

4.1. An overview of inequality measures $\quad 30$

4.2. Estimation of income distribution data 32

4.3. The structure of inequality in Turkey $\quad 34$

4.4. Problems in estimations of inequality 38

4. 5. Decomposition of income sources 41

4. 6. Is the reported decline in the Gini coefficient for real? 44

5. ANALYSIS OF WAGE SHARES BASED ON PANEL DATA 46 
5.1. Wage share 46

5.2. The model for examining changes in the wage share 47

5.3. The data used in the empirical analysis 52

5.4. The empirical analysis $\quad 53$

6. CONCLUSION

$\begin{array}{lr}\text { REFERENCES } & 65\end{array}$

$\begin{array}{lr}\text { APPENDIX-A } & 69\end{array}$

$\begin{array}{lr}\text { APPENDIX-B } & \mathbf{7 0}\end{array}$

$\begin{array}{ll}\text { APPENDIX-C } & 74\end{array}$

$\begin{array}{ll}\text { ABOUT THE AUTHOR } & 82\end{array}$ 
TABLE LIST

Page \#

Table-4.1 Number of households and household members surveyed.............. 33

Table-4.2 Gini Coefficients in Turkey ................................. 35

Table-4.3 The share of income factors in total income $(\%) \quad \ldots \ldots \ldots \ldots \ldots \ldots . . . \ldots 37$

Table-4.4 Wage shares calculated from the National Income Accounts (\%)... 38

Table-4.5 Shorrocks Income Decomposition Analysis.................................. 43

Table 5.1 The impact of trade flows on wage shares (1981-2001) .......... 55

Table 5.2 The impact of trade flows on wage shares in unskilled sectors(1981-2001).

Table 5.3 The impact of trade flows on wage shares in skilled sectors(19812001)..................................................................... 58

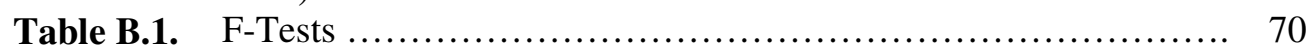

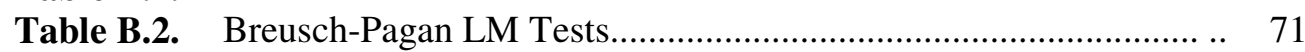

Table B.3. Hausman Test ..................................................... 71

Table B.4. Mundlak's Formulation ................................................. 72

Table B.5. Wooldridge Test .................................................................... 72

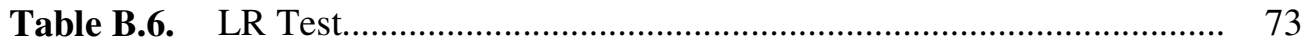


FIGURE LIST

$\underline{\text { Page \# }}$

Figure-2.1 Growth rates(\%) in the Turkish Economy..................... 4

Figure-2.2 Increase in (Foreign Trade Volume/GDP) after the trade

Figure-2.3 Changes in Exports/GDP and Imports/GDP (1980-2006)

Figure-2.4 Wage shares (total wages/value added) calculated from the Industry Statistics ....

Figure-2.5 Wage shares (total wages/value added) in manufacturing industry calculated from the national accounts data ....

Figure-3.1 Effects of shifts in labor demand curve in close and open economies.

Figure C.1 Change in the wage share in the unskilled sectors (1980-2001) 75

Figure C.2 Change in the wage share in the skilled sectors (1980-2001)...... 76

Figure C.3 Change in the export/value added ratio in the unskilled sectors (1980-2001).

Figure C.4 Change in the export/value added ratio in the skilled sectors (1980-2001)

Figure C.5 Change in the import/value added ratio in the unskilled sectors (1980-2001)

Figure C.6 Change in the import/value added ratio in the skilled sectors (1980-2001)

Figure C.7 Change in the inflation (1980-2001)

Figure C.8 Change in the real exchange rate (1980-2001) 


\section{ÖZET}

\section{KÜRESELLEŞME, TÜRKIYY'DEKİ ÜCRET PAYLARI VE GELIIR DAĞILIMI}

\section{Cem OYVAT}

Küreselleşmenin çoğunlukla işgücündeki esnekliği arttırdığı, işgücünün pazarlık gücünü azalttı̆̆ı ve sonuçta özellikle ticareti yapılabilen malların üretildiği sektörlerde ücret üstünde baskı kurduğu gözlemlenmiştir. Bu durum, ücret paylarında bir gerilemeye ve ülke içi eşitsizlikte bir artışa yol açabilmektedir. Gene de, küreselleşmenin eşitsizlik üzerindeki ekonomik etkileri duruma bağlı ve zamana özeldir.

1980 yılı sonrasında Türkiye serbestleşme politikaları uygulamaya başlamıştır. Serbestleşme politikaları, küreselleşmenin Türkiye üzerindeki etkilerini ticari akımları ve sermaye akımlarını arttırarak yükseltmiștir. Türkiye, 1980 yılından başlayarak ticari serbestleşme ve 1989 yılından başlayarak finansal serbestleşme dönemlerini yaşamaktadır. Böylece, serbestleşme politikaları bireysel ve fonksiyonel gelir dağılımı üzerinde de etkili olmuştur.

Bu tezde, gelir eşitsizliğinin dinamikleri incelenecek ve gelir faktörlerindeki serbestleşme dönemi sonrası değişimler dikkate alınarak analiz edilecektir. Gini katsayısında 1994-2005 yılları arasında gözlemlenen değişimler ve bu değişimlerin küreselleşme ile olan ilişkisi incelenecektir. Hanehalkı gelir anketlerinden elde edilen Gini katsayısının güvenilirliği değişik veri kaynakları ile karşılaştırılarak sorgulanacak, gözlemlenen tutarsızlıkların bireysel gelir dağılımı istatistikleri üzerindeki etkileri tartışılacaktır. Son olarak, artan ticari akımların imalat sanayindeki ücret paylarına olan etkisi, 1981-2001 yılları için ampirik bir analizle gösterilecektir. Aynı analiz ticari akımların, farklı nitelik düzeylerindeki işçilerin yoğun olduğu sektörlere olan etkisini görmek amacıyla, nitelikli ve niteliksiz sektörler için de yapılacaktır. Çıkan sonuçlar birbirleriyle karşılaştırılacak farklılıkların arkasında yatan nedenler detaylıca incelenecektir.

Anahtar Kelimeler: gelir dağılımı, ücret payı, küreselleşme, Türkiye

JEL Sinıflaması: D31, D33, D63, O52, F16 


\section{ABSTRACT \\ GLOBALIZATION, WAGE SHARES AND INCOME DISTRIBUTION IN TURKEY}

\section{Cem OYVAT}

Globalization is often observed to result in raising labor flexibility, lowering labor bargaining power and hence impose a downward pressure on wages especially in the sectors where tradable products are produced. This would result then in a deterioration of the wage share and raising inequality within developing countries. Yet the economy-wide effects of globalization on inequality seem to be dependent on particulars of each case, locally and timewise specific and ever-evolving.

After the year 1980, Turkey started to implement liberalization policies. The liberalization policies increased the impact of globalization on the Turkish economy by raising the trade and capital flows. Starting from the year 1980 Turkey has experienced trade liberalization and starting from the year 1989 Turkey has experienced financial liberalization periods. Thus, the liberalization policies also had an impact on the individual and functional income distribution.

In this paper the interactive dynamics of income inequality will be explored and analyzed by considering the changes in the structure of income sources in the post-liberalization era. The reasons behind the decline in the Gini coefficient between 1994-2005 will be analysed and its relationship with the globalization will be examined. The reliability of the Gini coefficient that comes from household income surveys will be questioned by using different data sources and the effects of inconsistencies on individual income distribution statistics will also be discussed. Finally, the negative impact of increasing trade flows on the wage shares in the manufacturing industry will be shown for the years 19812001, by an empirical analysis. The same analysis will also be made for the skilled and unskilled sectors in the manufacturing industry for examining the impact of trade flows on the sectors led by different skill groups. The results will be compared and the reasons behind these results will be examined in detail.

Keywords: income distribution, labor share, globalization, Turkey

JEL Classification: D31, D33, D63, O52, F16 


\section{INTRODUCTION}

Globalization is a process that changes many dynamics in the economies of many countries that it is being observed. Likewise many other issues, globalization is also effective on the structure of income distribution. Globalization is often observed to lower wage share and increase inequality by raising labor flexibility and lowering labor bargaining power. Yet the economy-wide effects of globalization on inequality seem to be dependent on particulars of each case, locally and time-wise specific and ever-evolving. In the post 1980 period, the globalization is also observed in Turkey through trade and financial liberalization and had specific effects on the distribution of income.

Starting from the year 1980, Turkey experienced a trade liberalization period. After the trade liberalization, the functional income distribution is affected negatively from the policies that aimed to raise the export competitiveness of the country. The wage shares had shown a declining trend after the year 1980. In the year 1989, Turkey experienced a financial liberalization. The financial liberalization raised the instability in the financial markets. With the impact of capital outflows two economic crises occurred in the years 1994 and 2001. The share of wages declined severely with the effect of the economic crises.

After the economic crisis in 2001, according to the official statistics, income inequality started to follow a consistent declining path. The Gini coefficient estimated declined from 0.44 to 0.38 between years 2002-2005. This value is far lower than the Gini coefficient of the year 1994, which is a year that another economic crisis is experienced. The Gini coefficient in Turkey was calculated as 0.49 in the year 1994.

The declining trend in Turkey can be thought as inconsistent with many theoretical and empirical works that claims that globalization will result with raising inequality 
in developing countries. The influence of globalization and neoliberal policies that started to be implemented after 1980's, has been seen more widely after the 2001 economic crisis. The amount of total imports has risen severely; the production in Turkey has become more dependent on import goods (Yeldan, 2007). Capital inflows have also increased and have become effective on high economic growth experienced on post 2001 period (Bulutay, 2005).

The aim this study is to examine the dynamics of inequality and the impact of globalization on the income distribution in Turkey. The study mainly focuses on the effects of trade liberalization on distribution rather than the impact of rising capital flows and FDI. However, the impact of financial crises on the wage shares is also shown in the empirical analysis.

In this study, firstly the post-liberalization period in the Turkish economy is examined. The changes in the functional income distribution are shown with the policies that affected inequality. Secondly in the third section of this study, the effects of globalization on income distribution are discussed by using theoretical and empirical framework on trade liberalization. The theories of different perspectives including the theories of neoclassical and political economy literature are analyzed. Empirical studies examining the influence of globalization on developing countries are also examined and the empirical studies on Turkey's income distribution are discussed.

In the fourth section of this study, the changes on functional income distribution statistics and potential reasons for the decline in the Gini coefficient is explored. The reliability of Turkstat income distribution statistics are also discussed. Income distribution statistics is compared with national accounts statistics, the changes in wage shares is examined by using national accounts statistics for gaining a deeper insight about functional income distribution. Lastly, in the fifth section, the impact of trade flows is examined by using panel data models. The impact of the changes on the wage shares in the manufacturing industry is shown and the reasons behind the changes in the wage shares are analyzed empirically. The same analysis is also done for the skilled and the unskilled sectors for showing the impact of globalization on different skill groups. 


\section{AN OVERVIEW OF THE TURKISH ECONOMY}

In this section, the post-liberalization period of the Turkish Economy is analyzed. The end of the import substitution regime and the changes in the post 1980 era is explained briefly. The components of export oriented policies are analyzed and the impact of capital inflows and the financial crises are examined. The distributional impacts of the trade and capital liberalization are also shown by analyzing the changes in the labor markets after the year 1980.

\subsection{Trade and capital account liberalization in the post 1980 era}

During the 1960's and the 1970's Turkey implemented policies that supported import substitution regime for the development of the national industry. The impact of the import substitution policies are observed more intensively in the second period of the import substitution strategy which is between years 1970-76. During the years 197076, Turkey implemented strategies encouraging the production of intermediate and consumption goods. In this period, the national industries are protected with quotes and high rates of tariffs; thus, the rents of protection are transfered to the national capital owners (Yeldan, 2001).

Between 1977-1979, Turkey experienced a problem in financing the foreign currency needs for imports. Thus, the currency gap resulted with an economic crisis. The aim of the import substitution regime was firstly raising the production of consumption goods by protecting the sectors producing these goods. As the sectors producing consumption goods improve up to a level, the production of capital and intermediate goods should be encouraged for declining the dependency of a country. In the second half of 1970's policies, aiming the improvement of the production of capital and intermediate goods were implemented. Some public investments were made in the sectors like electronics, machinery, electromechanics and high quality steel 
industries; however, the effort of rising intermediate and capital goods production were unsuccessful (Kepenek and Yentürk, 1999).

As a result, Turkey could not escape from its dependency on capital and intermediate goods imports. Thus, from the middle of the 1970's onwards, Turkey started to face a problem of current account deficit. Given budget deficits and the appreciated real exchange rate, the 1974 oil crisis raised Turkey's current account deficit. The rising current account deficit led Turkey into a debt crisis. As imports could not be financed by the foreign loans, the sectors dependent on imported goods contracted and the growth rate declined to $0.4 \%$ in 1979 and $-2.8 \%$ in 1980 (Figure-2.1).

Source: State Planning Organization, www.dpt.gov.tr

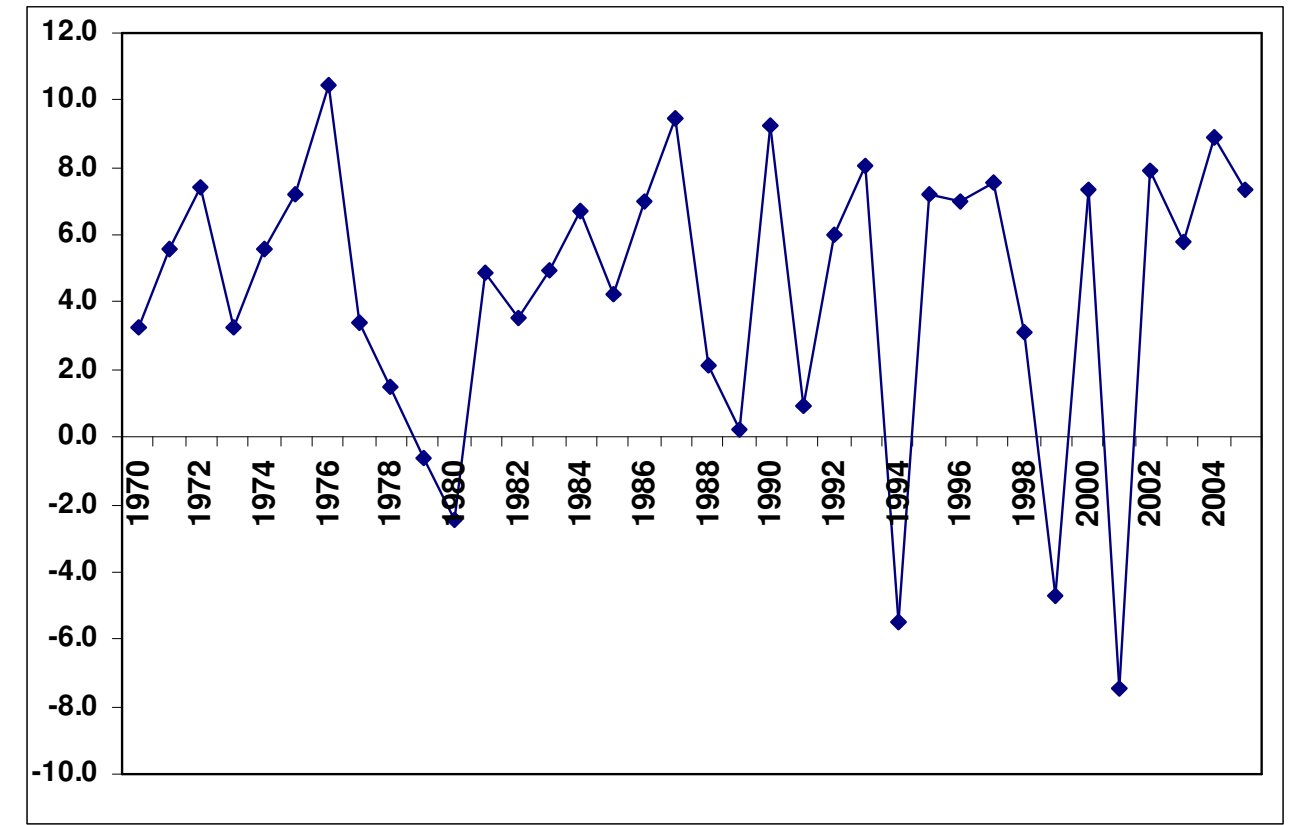

Figure-2.1: Growth rates(\%) in the Turkish Economy

As the economic depression got deeper in $24^{\text {th }}$ January 1980 , the Turkish government started to implement new economic policies aiming at the liberalization of the economy. The new economic policies supported liberal market prices in the economy and contained trade liberalization strategies that aimed increases in exports of goods and services (Figure-2.2). The improvement of export oriented sectors was supported by subsidies and the depreciation in the value of TL. The policies supporting the decline in real wages were also implemented after 1980. The aims of these policies were increasing investments by rising profit rates, increasing competitiveness of 
export oriented sectors by reducing the costs of labor and decreasing imports by reducing the demand in the internal market.

In the year 1989, the financial liberalization policies were implemented in Turkey. The financial liberalization contained the liberalization of capital flows and the liberalization in the usage of foreign currencies. Likewise many other developing countries that experienced financial liberalization, the amount of short term speculative capital flows that went in Turkey also increased dramatically after 1989. The high rates of interest also increased the amount of capital inflows into Turkey. The short term speculative capital flows financed the current account deficits and encouraged consumption and imports in The Turkish economy.

Source: The author's own calculations based on SPO and Turkstat statistics: www.dpt.gov.tr, www.turkstat.gov.tr

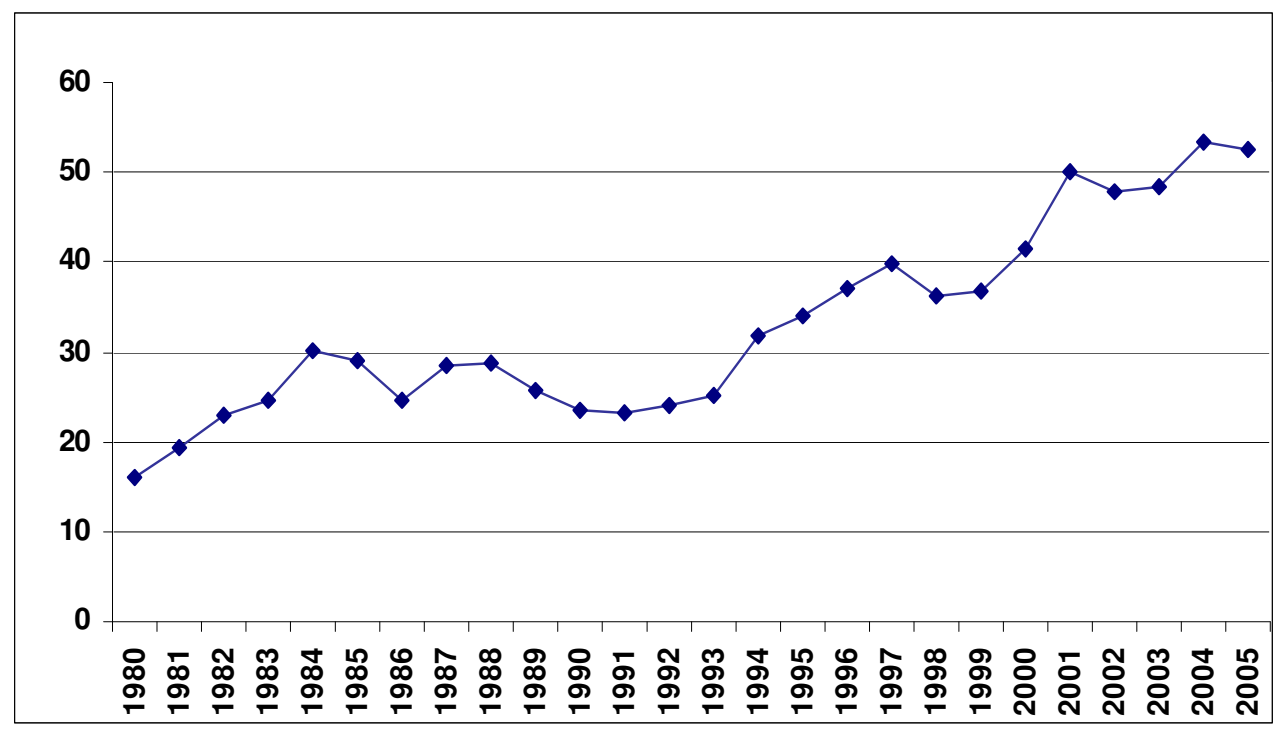

Figure-2.2: Increase in (Foreign Trade Volume/GDP) after the trade liberalization

The short term speculative profits lead Turkey to an unsustainable growth trend. The government budget deficits increase and the rise in imports resulted in a current account deficit problem. In the beginning of 1994, the current account deficit led to the expectation of devaluation of national currency. Thus, the declining reliability of the Turkish economy resulted in capital outflows and an economic crisis in the year 1994. With the effect of the economic crisis, GDP declined by $5.5 \%$ and the inflation rates rose to the level of $106 \%$. 
After 1994, strict monetary policies aiming to recover the declined reserves were implemented. High interest rate policy is used for the aim of raising the capability of borrowing. Also, the policies aiming the decline of the real wages were implemented for contracting the demand in the economy. After 1995, the capital inflows continued with the support of higher interest rates. However, 1997 Asian and 1998 Russian crises that occurred in these conditions affected national economy negatively. The decline in the demand of countries like Russia contracted the exports of Turkey. The lack of confidence formed after the Asian and Russian crises, again resulted with the capital outflows and another financial crisis in Turkey (Kepenek and Yentürk, 1999; Yeldan, 2001).

In the year 2000, Turkey started to implement a currency peg policy under the guidance of the IMF. The currency peg policy aimed to decrease the inflation by letting the dollar to float in a tight band. However, the currency policy could not decrease the inflation rate to the expected levels. The monetary policies of the economic program became inefficient on avoiding the capital outflows caused by rising risks in the banking system, increasing current account deficits. Thus, in the year 2001 Turkey faced high amounts of capital outflows that resulted with the 2001 economic crisis. The outcomes of 2001 crisis were very severe. The GDP contracted by $7.4 \%$, the currency lost its value by $\% 51$ against dollar (Boratav, 2003; Onaran, 2007b).

After the economic crisis a new economic strategy was taken up that consisted of inflation targeting, high interest rates and reduction in government expenditures and public involvement in economy. After the economic crisis the IMF provided financial assistance and involved in the management of the new economic strategy. The government followed a contractionary fiscal policy for reaching the goal of a primary surplus of the $6.5 \%$ of the GNP. For attaining the goal of primary surplus, neoliberal policies were adopted. Subsidies on agriculture were reduced and many public institutions were privatized (Yeldan, 2007).

After the economic crisis, globalization affected the trade balances of Turkey more widely. As a result of the high interest rate policy implemented, Turkish Lira has become overvalued. According to the TR Central Bank (2007) data, the real value of the Turkish Lira appreciated by $37.7 \%$ between years 2002-2005 with the effect of 
high interest rate policy. The real appreciation of Turkish Lira stimulated imports and the ratio of imports to GDP rose to $34.9 \%$ in 2006 (Figure-2.3). Traditional Turkish exports also lost their competitiveness; therefore the export structure of Turkey has altered. Import dependent, assembly line industries became the new export lines. Cheap raw materials and intermediate products have been imported, got assembled in Turkey and exported. Since most exports are import-dependent, they have a low capacity to generate value-added and employment (Yeldan, 2007).

Therefore, exports are not sufficient for closing foreign trade gap that reached to the level of 54.0 billion $\$$ in 2006 . As a result of policies implemented, the size of foreign trade increased to 225.0 billion $\$$ and the foreign trade deficit/GDP ratio rose to the dramatic value of $13.5 \%$.

Source: The author's own calculations based on SPO and Turkstat statistics: www.dpt.gov.tr, www.turkstat.gov.tr

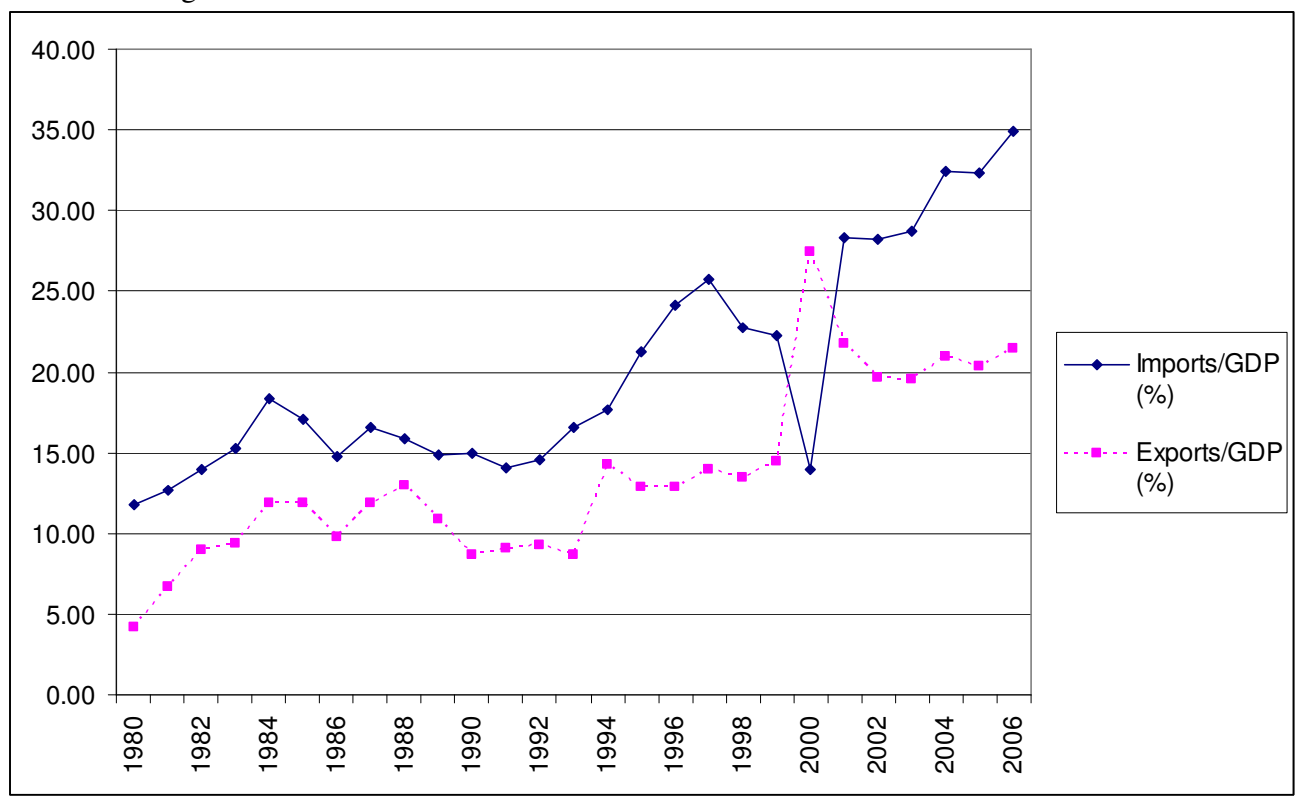

Figure-2.3: Changes in Exports/GDP and Imports/GDP (1980-2006)

\subsection{An overview of the changes in inequality and labor markets}

As noted above starting from 1977, the import substitution regime gave negative outcomes and the Turkish economy experienced a contraction period between the years 1977-1979. Unlike the 1994 and 2001 crises, the depression in the years 19771979 caused an increase in the share of wages in industry. The share of wages in the 
value added increased from $28 \%$ in 1975 to $37 \%$ in 1979 . The import substitution regime tolerated high amounts of wages with the support of high rents provided by the protection of national industries. Thus, the wages in the industry were not affected very negatively from the economic crisis (Yeldan, 2001).

In $24^{\text {th }}$ January 1980 Turkey started implementing a liberalization program. However, the policies that aim of the depression of wages could not be implemented until the military coup that occurred in $12^{\text {nd }}$ September 1980 . The policies for the contraction of wages were targeting an increase in the export competitiveness and a contraction in the domestic demand. After the coup, the military regime had an attack on the labor unions. Many representatives of labor unions were arrested and the assets of unions were seized, which resulted in the demolition of the unions. After 1980, the unionization of government officials was restricted. The process of strikes was also hardened. The number of sectors where strikes were allowed declined and new prerequisites for the membership of unions were implemented (Boratav, 2003; Kepenek and Yentürk, 1999).

Source: The author's own calculations based on Turkstat Annual Industry Statistics, the statistics contain firms that contain at least 10 workers.

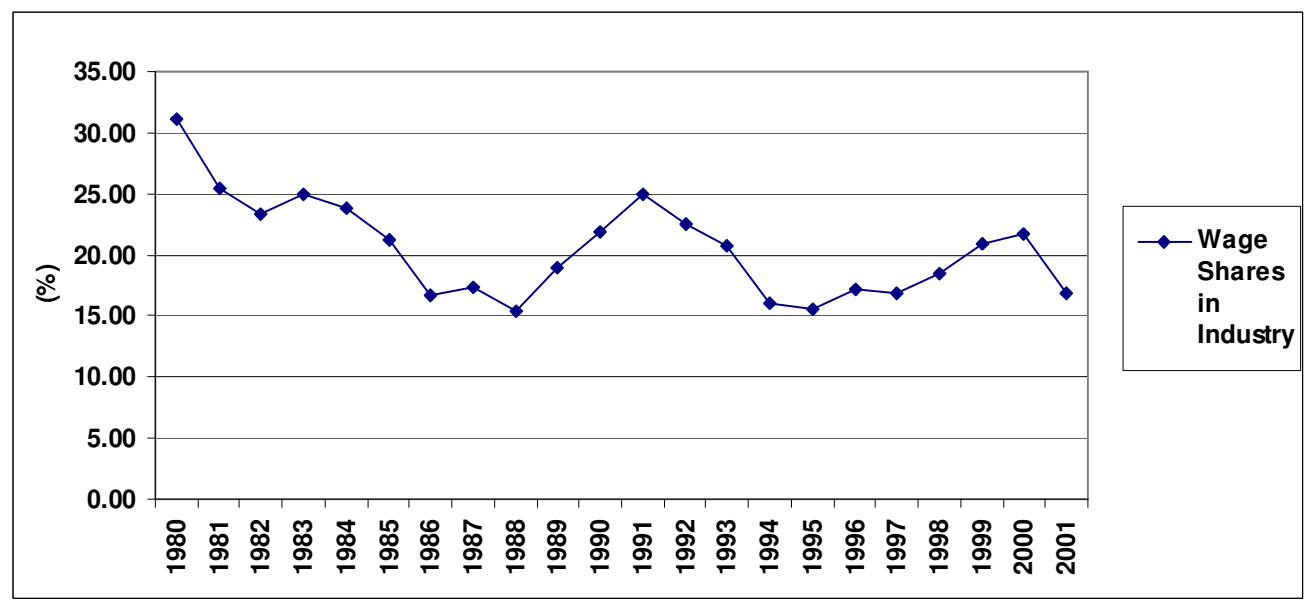

Figure-2.4: Wage shares (total wages/value added) calculated from the Industry Statistics (1980-2001)

The policies targeting the wage contraction indeed led to a dramatic decline in the wage share in industry dramatically. Between the years 1980-1988, the wage share in industry declined to $15 \%$ from the level of $31 \%$, expect a brief period of rise in the early 1990's, industry wages as a share of value added have fluctuated in the 15 to 
$20 \%$ interval through the 2000's (Figure- 2.4). With the decline in wage share domestic demand also contracted and the amount of exports rose. It must also be noted that the high inflation rates in this period had an important role in the squeeze of wages. In the year 1988, the GDP growth was only $2.1 \%$ and the inflation rate rose to $75 \%$. The conditions of 1988 were signaling stagflation. Thus, in the year 1989 the wage suppression policy ended and new policies were implemented. The public expenditures rose and the rising public expenditures were financed by the capital inflows that came after the financial liberalization. Also with the support of the pricing policy of the public sector, the ratio of the intermediate costs to labor costs declined from 11.8 in 1988 to 6.5 in 1991 . The firms could endure the rise in the wage costs with the support of decline in non-wage costs (Boratav, Yeldan and Köse, 2000).

Although the restrictions on unions continued, starting from the year 1987 onwards the number of strikes rose to a level even higher than the pre 1980 period. The number of strikes reached to the peak level of 458 and 398 in the years 1990 and 1991 (Yentürk and Kepenek, 1999). The movements of the unions also had a positive impact in the rise of wages. As a result of labor movements and the expansionary public policies, the rate of unemployment showed a slight decline and the wages rose dramatically. Overall, from 1990's onwards a positive relationship developed with real wages in manufacturing industry exhibiting flexibility with respect to changes in the unemployment rate (Onaran, 2002; İlkkaracan \& Selim, 2001; İlkkaracan, 2004).

The rising current account deficit and the deterioration of the fiscal balances resulted with the 1994 economic crisis. The policies implemented after 1994 also contained tight monetary policies and aimed to contract the demand by decreasing the real wages. The economy again started to follow the strategy of rising export competitiveness by declining the wage costs (Yeldan, 2001; Boratav, Yeldan and Köse, 2000). Thus, the wage share experienced a huge decline in the year 1994. The wage share in the industry could not reach to its level before crisis until the year 1999.

In the year 2001, Turkey experienced another economic crisis. The economic crisis resulted with a huge amount of contraction in GDP. The distributional outcomes of 
the economic crisis were even more severe. The rate of urban unemployment rose by $3.2 \%$ in 2001 and in 2002 the rate of urban unemployment again rose by $2.5 \%$ and reached to the level of $15.1 \%$. Also, the wage share deteriorated by $14.92 \%$ in manufacturing sector in 2001 (Figure-2.5). These results show that the economic crisis experienced in 2001 also had negative distributional outcomes.

Source: Turkstat (www.tuik.gov.tr) and the author's own calculations based on GDP by income and GDP by production data.

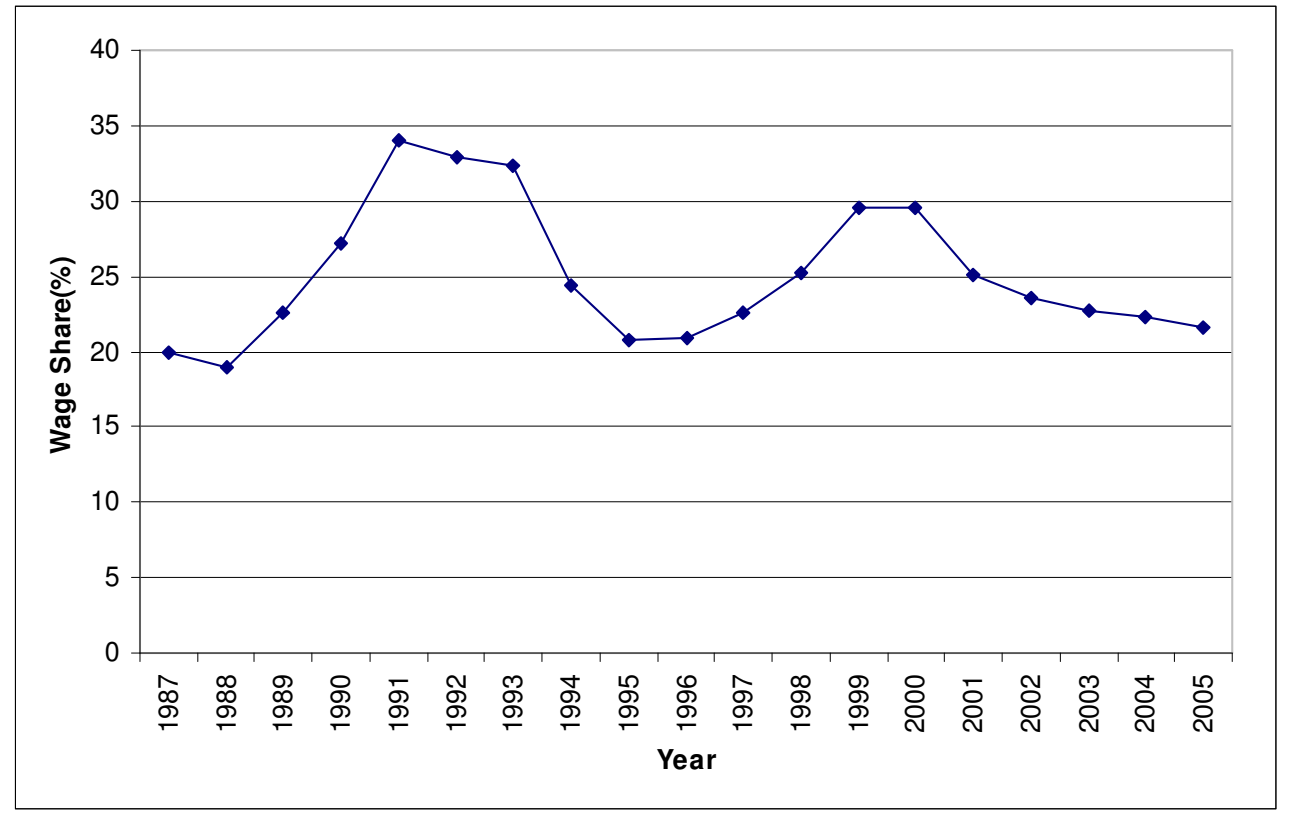

Figure-2.5: Wage shares (total wages/value added) in manufacturing industry calculated from the national accounts data (1987-2005)

In this section, the changes in the Turkish economy after 1980 are analyzed briefly. The policies implemented and their consequences are examined and the distributional impact of trade and capital liberalization is shown by using statistics depicting the changes in the labor markets in the post-liberalization era. The statistics show that the wage share in industry followed a declining path in the post 1980 period. The wage share had increased in some of the periods that capital inflows are observed; however, the positive impact of the capital inflows was reduced severely at the periods of the economic crises that capital outflows are observed. 


\section{AN OVERVIEW OF IMPACT OF GLOBALIZATION ON INEQUALITY}

Globalization might affect developing and developed countries both by raising trade flows and capital flows in the country. Many countries implement policies containing trade and capital liberalization; hence the countries become open to the natural effects of globalization. Both capital and trade flows are effective on changes in inequality; therefore, globalization has many distributional outcomes. In this section, the views on the distributional impact of the trade flows are examined in detail. The empirical studies on the individual and functional income distribution made are also shown for examining the effects of trade flows on the inequality.

\section{1. Setting the theoretical framework: The effects of globalization on the distribution of income}

There are many theories that state trade liberalization affects real wages. Therefore, trade liberalization is considered to have influence on functional income distribution. The traditional trade theory based on both Ricardian and Heckscher-Ohlin theories expect that trade liberalization will result in specialization of production according to comparative advantage; the aggregate income is expected to increase as a result. According to the joint outcome of Stolper-Samuelson and Heckscher-Ohlin theories, trade liberalization has positive effects on returns to capital in capital abundant developed countries, due to the possible increase in the production of capital intensive products. Stolper-Samuelson theory states that real wages may fall in developed countries, as the countries specialize on capital intensive industries. Factor prices are expected to equalize through trade openness across the countries, since the relative prices for identical factors of production in the same market are expected equal each other because of competition. Therefore, the theory states that wages for identical jobs in developing and developed countries tend to approach each other, 
which would cause decline in wages of workers in developed countries. As a result, real wages in capital abundant developed countries may be affected negatively.

For the labor abundant developing countries the opposite effects would be expected, since the developing countries are expected to specialize on the production of the labor abundant goods. According to the Stolper-Samuelson theorem, as the developing countries specialize on labor abundant goods, the demand on the labor and hence the wages in the developing countries rise.

The labor market theories of political economy literature claims that trade liberalization will have negative distributional effects both in developing and developed countries. According to the political economy approach liberal policies and globalization have negative effects on workers both in developed and developing countries due to raising competition among countries for attracting investments(Block, Dauterive and Levendis, 2007; Kaplinsky, 2001; Onaran, 2007a; Pollin, 2002).

First of all, for attracting globally mobile investments many countries reduce their rates of taxes for capital. Therefore, a reduction in tax revenues and social expenditures due to trade liberalization is expected to be observed. This claim is proven by the empirical estimations of Rodrik (1997) shows that both in the OECD and developing countries globalization made taxing of capital more difficult; thus, reduced the ability of governments to make social expenditures. Also, Rodrik claims that since capital mobility makes the taxing of capital more difficult; the governments will choose to increase the taxes collected from labor for preventing the reduction in their revenues. Hence, labor will carry a growing share of the tax burden as a result of globalization.

In addition, Kaplinsky (2001) claims that the desire to promote openness results with reduction in tariff revenues. This result might be true for many countries; however, it should be noted that decline in the rates of tariff could raise the amount of governments' total revenues by increasing the amounts of imports. Hence, the effect of reduction in the tariff rates on the governments' total tariff revenues can be considered as ambiguous. 
Secondly, it is argued that, globalization has labor disciplining effects. Globalization increases global substitutability of labor, due to openness and capital mobility. In order to attract foreign investments, developing countries allow for greater capital mobility, liberalize their trade laws and weaken their labor laws. Once the investments are made the threat of withdrawal threatens the bargaining power of workers. Firms also act more aggressively during bargaining process due to increased competitive pressures caused by globalization. As a result, the threat effects of international capital mobility and outsourcing, weakens the bargaining power of workers, unions, and regulatory agencies and the wage share of workers, particularly unskilled workers will be reduced according to the theories of political economy literature (Onaran, 2007a; Pollin, 2002; Block, Dauterive and Levendis, 2007).

Also the same pressures that reduce workers' bargaining power reduce the political power of labor. As a result, the interests of labor relegate to the second place and concepts like "competitiveness" become popular. The receptivity of public changes and ideas on labor are usually suppressed by a "protectionalist tenor". (Rodrik, 1997) This process also effects the position of labor negatively.

Moreover, globalization also has an impact on the volatility of wages and employment. Since workers can be more easily substituted by the foreign workers, the demand for labor becomes more elastic and the demand curve of labor becomes flatter. Hence, as a result the changes in labor demand will have larger effects on wages and employment. As Figure-1 shows, equivalent amounts of shifts in labor demand will raise wages and employment more in open economies compared to the close economies. Thus, the changes and hence the declines in labor demand will be more realized in the open economies. This will have a negative effect especially on the low-skilled workers, since the low-skilled workers usually face longer unemployment periods and larger cuts in wages in the reemployment period (Rodrik,1997).

Another focus of studies on the distributional effects of globalization concerns changes in the relative wages of workers that work in different sectors, regions and that have different educational levels. Trade liberalization might be effective on relative wages of workers that work in different sectors, regions and that have 
education levels. There are many studies that examine how trade liberalization influences the wages of workers with different skill levels. Reasons for the changes in relative wages between skilled and unskilled workers and their relationship between trade flows are commonly being discussed.

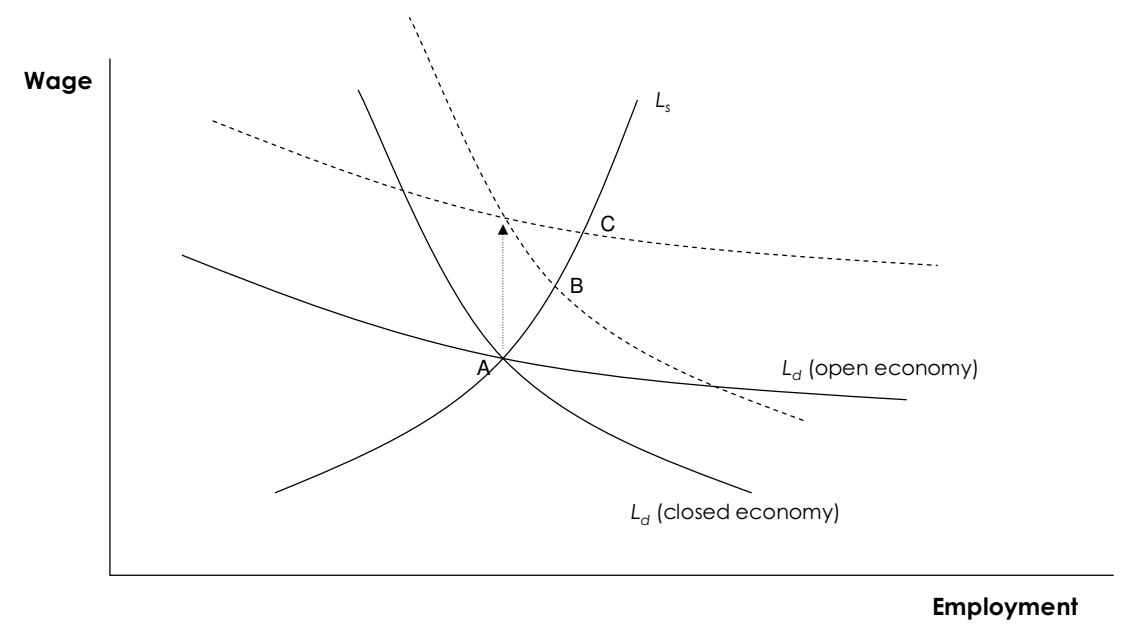

Figure-3.1: Effects of shifts in labor demand curve in closed and open economies

Source: Rodrik, D.(1997), Has Globalization Gone Too Far?, Institute for International Economics, Washington D.C.

According to the extension of the Stolper-Samuelson theorem globalization will have positive effect on unskilled workers in developing countries. The theorem states that since developing countries will specialize on unskilled labor intensive sectors, the demand for lower skilled workers utilized in these sectors will increase. As a result, this process would be expected to have a positive effect on wages of unskilled workers and trade liberalization would have positive distributional outcomes, as the wage share of unskilled workers in developing countries increase. The opposite effect is expected to be seen in the developed countries, as the developed countries specialize on the skilled goods and hence, the relative demand for the skilled-labor in the developed countries will rise.

Consistent with the predictions of the Stolper-Samuelson theorem, the US experienced a relative decline in the demand and wages of the low skilled workers in the 1980's and 1990's. In Europe, the institutions that protect the wages of the low paid workers have not allowed the wage gap to be widened as much as in the US. 
However, Europe faced another problem; since the demand for low-skilled workers also fell in Europe, an unemployment problem appeared for the low-skilled workers (Freeman, 1995).

However, according to Davis and Mishra (2007), the Stopler-Samuelson theorem cannot be used for analyzing the effects of liberalization on unskilled labor in unskilled labor abundant countries. Davis and Mishra (2007) claim that the StolperSamuelson theorem holds only if countries produce all goods. The reason for that is that a reduction in tariffs of non-competing goods could give in different results. For incidence, a tariff reduction in an intermediate good that is not produced locally will naturally not have a direct effect on wages. However, if this intermediate good is used by a skilled sector in a developing country; a reduction in the tariffs of this intermediate good will increase the returns of high-skill labor, since the imports of the intermediate good will increase the production and the labor demand in the skilled sector. Hence the relative wages of the skilled labor and wage inequality will be increased, which is inconsistent with the results of Stolper-Samuelson theorem. Also Stolper-Samuelson's model assumes that imports from abroad and domestically produced goods are close substitutes; however, this might not be necessarily true.

The Stopler-Samuelson theorem is also inconsistent with the data that shows rising gap between skilled and unskilled labor in the last two decades in many developing countries (Goldberg and Pavcnik, 2007). One of the reasons for this result might be skill-biased technological change. Globalization results in raising competition and provides incentives for upgrading plants in the developing countries. Trade could increase the relative prices of skill-biased products, making these products more profitable and causing a skill-biased technical change (Acemoğlu, 2003). Besides, even the countries those have a comparative advantage in unskilled-intensive sectors still need to use skilled workers for competing in global markets (Harrison, 2005). Hence, this technical change may increase skill premia and increase the relative wages of skilled workers in the developing countries. Also, technical change reduces demand for low-skilled workers, as technologies like computers and other information and communications technologies equipment could act as a substitute for unskilled labor. This process widens the wage gap between high-skilled and lowskilled workers (Goldberg and Pavcnik, 2007; Acemoğlu, 2003; IMF, 2007b). 
Another reason for the inconsistency of the Stolper-Samuelson theorem could be differences on the perception of skill. An industry that is considered as high skill intensive in a developed country might be considered as intermediate or low skill intensive in a developing country. In this case, as the developing country will specialize in an industry that is considered as high or intermediate skill intensive; the trade liberalization will worsen the income distribution (Lee and Vivarelli, 2006; Davis and Mishra, 2007).

Feenstra and Hanson (1997) claim that the same situation is also seen in the outsourcing activities that comes to the developing countries from the developed countries. The activities that are outsourced use large amounts of unskilled labor according to the developed countries' perspective and use large amounts of skilled labor according to the developing countries perspective. Thus, the relative demand for the unskilled labor is expected decline in the developed countries and the relative demand for the skilled labor is expected to rise in the developing ones. Therefore, an outsourcing activity that comes from developed to developing countries is expected to result in rising wage inequality in both types of countries.

Also with the entry of China and other low income Asian countries into the world market of labor intensive industries, medium income developing countries like Turkey have lost their comparative advantage in unskilled labour intensive industries like textiles. Increased openness changed the comparative advantage of medium income developing countries towards medium skill intensive products. Therefore, as the production of low skill intensive products was replaced by imports from low income countries, relative wages of unskilled workers decreased in many medium income developing countries (Wood, 1999).

Krugman (2008) considers the low income countries' position from another point of view and shows that high-skilled products like computer and electronic products are started to be produced in higher volumes in the low income countries. Krugman (2008) claims that there is a specialization in the production of the computer and electronic products; some parts of the computer and electronic products are produced in the low income countries and some parts of these products are produced in the high income countries. Hence, skilled workers in the high income countries are not affected by the low income countries' rising production of technology goods. 
However, the production pattern might change in the future and as the low income countries continue to specialize in high-skilled goods; the wages of high-skilled labor in the high income countries might get negatively affected.

Globalization is expected to raise the substitutability of labor especially in the unskilled intensive activities. Since the substitutability of the unskilled labor is easier compared to the skilled labor, the bargaining power of the unskilled labor will be affected more from the rising flows of trade. As a result the relative wages of unskilled labor is could decline more compared to the unskilled labor and hence, the wage inequality both in the developing and developed countries could rise (Rodrik, 1997; Onaran, 2007a; Milanovic and Squire, 2005).

Also the bargaining power of workers is expected to deteriorate less in the capital intensive sectors compared to the labor intensive sectors. The reason for that is mainly in the capital intensive sectors labor is relatively an unimportant factor of production. Hence, the costs of labor will be less important in the firms' decisions. Secondly, mostly labor-intensive industries are small or medium size firms. In many of these firms, unskilled workers work in small sweatshops with the owners that are opposed to labor organization. In these small firms that are vertically disintegrated a strike in a single firm will not be able to have a significant impact on the sector. Thus, the impact of labor organizations is less in labor intensive sectors. Therefore, labor intensive sectors are more likely to be affected from the weakening of labor's bargaining power that is caused by globalization (Bohle \& Greskovits, 2007).

Thus, globalization could increase the wage gap between skilled and unskilled labor, as the wages in the skilled capital intensive activities are expected to rise relatively compared to the unskilled labor intensive activities with the increase in the trade flows. Hence, globalization could raise the individual income inequality by raising the inequality within the wages.

\section{2. Distributional Effects of Globalization: Empirical Studies}

\section{2. a. Income Distribution Across and Within Countries}

There are many empirical studies that show the distributional effects of globalization on developing and developed countries. The studies on global income distribution 
show that the effects of globalization on income distribution across countries are positive (Sala-i Martin, 2002; Chotikapanich, et al., 2007). On the other hand, the common result of many empirical studies is that the inequality within countries particularly developing countries rise with the effects of globalization.

Milanovic (2005) empirically explored the effects of openness on income distribution of developing and developed countries by using data containing shares of income deciles of 90 countries. He found that openness has different distributional effects on low and high income countries by making a cross-country analysis. The income share of low and middle income deciles fall in countries with PPP income per capita below 5000-6000\$. The income share of low and middle classes start to rise in countries with PPP above 5000-6000\$ with the effect of openness. Milanovic (2005) explains these results with Kuznets-type theories. He claims that globalization could produce labor movement from agriculture towards sectors like industry and services where wage differences are assumed to be higher. Therefore, globalization could raise inequality in developing countries.

There are also studies that examine how global inequality changed in the years of globalization. The global inequality is usually found by making an analysis that the mean incomes and within country inequalities are considered by attributing the weights of the countries according to their population. The estimations of many global income inequality studies show that inequality within countries has risen in recent years. In a study of Sala-i Martin (2002), changes in global inequality between years 1970-1998 are examined by using data of 125 countries. He calculated changes in global income distribution by using many measures including Theil, Atkinson and variance of log-income indexes. According to the calculations of Sala-i Martin(2002), global inequality has decreased according to indexes that measure aggregate global inequality mainly due to the high growth of China. However, the inequality within countries has increased between years 1970-1998. Sala-i Martin states that the Theil Index within countries has increased from 0.23 in 1970 to 0.28 in 1998, which means the inequality in the countries have increased in the period of study.

An empirical study made by Chotikapanich et al. (2007) also estimates that the global inequality has declined between years 1993-2000 by using the data of 91 
countries. Gini and Theil index are used for estimating global inequality and a decline in global inequality is found according to both indices. However, global inequality is also calculated by excluding China and increase in global inequality is found according to both indexes. This estimation proves that the high growth of China is an important factor of global inequality reduction. Theil Index within the countries is also calculated for estimating inequality in the countries. Theil Index is found to be increased from 0.29 to 0.30 between the years 1993-2000 in which the effects of globalization has been seen more widely. The inequality within countries has increased even more in the data excluding China. Within countries inequality excluding China has risen from 0.27 in 1993 to 0.31 in 2000. Income inequality has increased particularly in the countries that are located in Eastern Europe, Latin America and Africa; which show globalization has caused an increase in inequality in middle income and low income countries.

According to a study published in the World Economic Outlook October 2007 Issue (IMF, 2007a), the main reason for increasing inequality in the last two decades is found to be technological progress rather than globalization. WEO's model is estimated on a panel of 51 countries over 1980-2003. Also additional tests are made by spliting data to developing and developed countries. In the models variables like the exports to GDP ratio and tariff rates are used for estimating the impact of trade globalization and variables like the ratio of inward FDI stock to GDP and the ratio of cross-border assets and liabilities are used for estimating financial globalization. Control variables are also used for testing the effects of technological improvement, education and agriculture and industry employment shares.

The share of information and communications technology in total capital stock is considered as the measure of technological process. According to the model, the share of ICT increases the income inequality mostly. Technological improvement has a disequalizing effect both in the developing and the developed countries, since technology could exacerbate the income gap between skilled and unskilled workers. However, it is also important to consider that international trade could result with skilled-biased technological change both in the advanced and developing countries (Acemoğlu, 2003). Hence, technological change could not be considered entirely independent from trade (Rodrik, 1998). 
$\operatorname{IMF}(2007 a)$ finds that globalization has a relatively smaller disequalizing effect overall, reflecting the positive impact of trade flows and a negative impact from FDI. However, in the model where the sectoral export ratios are examined, only increases in the agricultural exports have a significant disequalizing effect. The effects of the rise in manufacturing and services exports on inequality are insignificant. Also, in advanced countries rising imports from developing countries result in rising inequality. The inward FDI flows has a significant negative impact on the distribution of income, since inward FDI increases the demand for the skilled labor. Also the outward FDI flows raise the inequality in the developed countries, since outward FDI weakens the demand for relatively low-skilled workers in the developed countries. The estimations of WEO also show that education has an inequality reducing impact. Also, a decline in agriculture employment share and an increase in industry employment share result in a decline in inequality, since shift of underemployed agriculture workers from agriculture to industry raise the relative productivity in agriculture. Besides, the productivity and incomes are higher in industry compared to agriculture. According to the IMF this result could be considered as a positive impact of globalization, since globalization encourages the immigration from rural to urban areas by increasing the productivity in the cities.

Many empirical works focus also on the relationship between globalization and wage shares, functional income distribution. Harrison (2002) developed a model using the bargaining framework between capital and labor. By using a Nash bargaining model the following equation is found for estimating the labor shares:

$S_{L t}=y_{0}+y_{1} \ln \left(L_{t} / K_{t}\right)+1 / 2\left(\Phi_{L} v_{L} / G(R)-\Phi_{K} v_{K} / G(R)\right)+\left(f_{K}-f_{L}\right) / 2$

$S_{L t}=$ labor share in year $\mathrm{t}$

$L_{t}=$ labor stock in year $\mathrm{t}$

$K_{t}=$ capital stock in year $\mathrm{t}$

$G(R)=$ total revenue

$v_{L}=$ units of labor in production

$v_{K}=$ units of capital in production
$\Phi_{L}=$ premium of labor for relocating abroad

$\Phi_{K}=$ premium of capital for relocating abroad

$f_{K}=$ fixed relocating cost of capital

$f_{L}=$ fixed relocating cost of labor 
As the model presents, the bargaining power of labor weakens as the fixed cost of capital for leaving country declines and the fixed cost of labor for leaving country rises. The model shows that a globalization that occurs with lowering restrictions on capital flows and strict immigration laws results with declines in labor shares.

The estimations of the model is tested by using extra variables including trade flows/GDP ratio(trade shares), nominal exchange rate, FDI, government expenditure/GDP and a crisis dummy. The capital controls are estimated by a measure ranging between 0-5. Both OLS and IV estimations are made for the model. The sample countries are also separated into two and the model is separately tested for the countries that have GDP for capita below and above median GDP per capita in 1985.

The capital controls variable is used for examining the fixed costs of relocating capital. For examining the premium of capital for relocating labor, nominal exchange rate is used; since relocating of capital results in bigger premium as the local currency appreciates. Also, it can be assumed that an increase in the premium of capital for relocating abroad and a decline in fixed relocating cost of capital will increase the trade flows/GDP ratio. Either outsourcing a part of production or an import of a product will be more profitable as moving capital gets easier. Hence, it can be assumed that easing of moving capital could be associated with the trade flows/GDP ratio. Thus, a trade flows/GDP ratio is used in the regression.

As expected in the theoretical model, an increase in capital controls significantly raises the labor share. Also, the trade shares are found to have a negative effect on the labor shares. However, according to the results of the IV estimation, the negative impact of the trade shares is more significant and has a bigger magnitude for the labor shares in poorer countries. This result also matches with the estimations of Milanovic (2005).

The inward FDI also is found to have a negative impact on labor share; however, this impact is restricted to the rich countries. The exchange rate crisis is found to lead dramatic declines in the labor shares in the poorer countries. The increases in government expenditures are positively correlated with the labor shares both in poor 
and rich countries. These results clearly prove the negative impact of globalization on the labor shares.

Another study on the effect of globalization on the labor income share, rather than the impact of trade flows, focuses on the effect of offshoring, immigration and relative trade prices on labor shares in the advanced countries (IMF, 2007b). The model is estimated on a panel of 18 countries over 1982-2002. Variables like relative export and import prices, labor-capital ratio, offshoring, immigration and information and communications technology are used in the panel regression.

According to the results of estimation, offshoring and immigration are found to be negatively correlated with the labor share. As people immigrate to the developed countries, the labor supply rise and the domestic labor in these countries are negatively affected. The negative impact of offshoring on labor shares is much more in the skilled sectors compared to the labor shares in unskilled sectors. This result is consistent with the assumption that offshoring is mostly driven by offshoring of skilled inputs rather than unskilled inputs. Higher relative export prices and lower relative import prices result with the lower labor share in advanced countries. Since advanced countries' imports from developing countries are relatively labor intensive, the wages in the advanced countries are negatively affected from declines in relative import prices.

The effect of trade flows on the labor shares of the Western European countries and the Central and Eastern European countries (CEEC) is also examined in another panel regression (Breuss, 2007). The study examines the impact of trade flows for both the Western European countries and the CEEC in different regressions. The effects of the trade between the Western European countries and the CEEC and the trade that Western European countries and the CEEC make with the rest of world are used in the regression. The effects of FDI on the labor shares of the both groups of countries are also examined.

According to the results of the study, the trade between the Western European countries and the CEEC has a negative impact on the labor shares of both groups of countries. This result shows that the increasing trade liberalization between the EU15 and CEEC countries has contributed to declines in the labor shares. FDI inflows 
also exert a weak negative pressure on the labor share in the Western European countries. For the CEEC the impact of FDI on the labor shares is found to be weakly negative.

The impact of trade flows on the wage inequality is also examined in some of the articles. Milanovic and Squire (2005) found that the tariff reduction resulted in higher inter-occupational and inter-industry wage inequality in poorer countries (below the world median income) and the reverse in richer countries by making a cross-country analysis covering the period between the years 1980-2000.

First the impact of changes in tariffs on the inter-occupational inequality measured by the Gini is examined. Variables like change in tariff rates, ln (GDP per capita), trade union members as $\%$ of labor force and the percentage of workers covered by collective bargaining is used in the panel regression. Change in tariff rates* $\ln$ (GDP per capita) is also used for examining the impact of reduction in tariff rates on the inter-occupational wage inequalities of countries with different levels of income. The regression shows that the reduction in tariffs reduces the inter-occupational wage inequality in the countries with PPP above $\$ 5000$ and the reverse effect is seen in the countries with PPP below $\$ 5000$. However, the results provide some weak evidence that reduction in tariff rate contributes to inter-occupational wage in poor countries. Hence, these results should be examined with caution.

The impact of changes in tariffs on the inter-industry inequality measured by the Theil index is also examined. Change in tariffs rates, social expenditures as $\%$ of GDP, $\operatorname{Ln}$ (GDP per capita), trade union member as $\%$ of labor force, number of ILO conventions signed are used in the panel regression. Again a variable like change in tariff* $\ln$ (GDP per capita) is used for observing the effects of changes in high and low income countries. A decline in tariff rates is found to reduce the inter-industry inequality in high income countries and increase the inter-industry inequality in the low income countries. Both of these effects are found to be statistically significant.

The impact of trade liberalization on the wage inequality between traded and nontraded sectors are examined in a study made for Brazil (Arbache, Dickerson and Green, 2004). The individual data from the household surveys for the years 19811999 are used for the study. In the year 1990 the period of trade liberalization started 
in the Brazil, hence the period starting from 1990 is described as the postliberalization period. Both for the pre-liberalization and post-liberalization periods, the wages in the non-traded sectors are higher than the wages in traded sectors. Firstly, the wage disadvantage of working in traded sectors is examined in a panel regression by using dummies like traded sector, traded sector*post-liberalization, non-traded sector*post-liberalization and variables for experience, gender and education. According to the results, the negative impact of the trade dummy on wages widened from $7.6 \%$ to $15.4 \%$ with the effect of trade liberalization. This might be caused by the reduction of bargaining power of unions in the industries that are affected by trade.

In the same study, another regression is made for examining the impact of trade liberalization in the traded sector on the wages of workers that have different education levels. Hence, six dummies are formed by multiplying the given education dummies with the dummy of post-liberalization years. Education, experience and gender variables are again also used in the regression as control variables. The effect of liberalization is found as significantly negative for the wages of workers in the lowest four education levels. However, the effect of liberalization is insignificant for the wages workers that completed either their secondary education or collage education. Thus, it is clear that in Brazil in the traded sector, the wages of unskilled workers are affected much negatively compared to the wages of skilled workers.

The empirical studies that examine the relation income distribution and globalization are mostly inconsistent with the Stolper-Samuelson theorem. The studies show that the increasing trade flows has a negative impact on the individual, functional and within wage inequality specifically in the developing countries. Thus, the empirical results rather prove the assumptions of the political economy literature.

\section{2. b. Studies on Inequality in Turkey}

There is number of empirical studies examining the changes of income distribution in Turkey. While most of those studies examine the dynamics of the income distribution, a few also focus on the relationship between functional income distribution and raising trade flows. 
One of the most extensive studies on income distribution in Turkey is made by TUSIAD (2000). In this research the dynamics of income inequality in Turkey is examined using the income distribution data for the years 1987 and 1994. The reasons behind the income inequality are explored by considering the role of income factors as well as regional and educational differences.

The decomposition analysis made for examining the effect of education level on the Gini coefficient shows that the educational gap significantly negatively affected income inequality in 1994. The income level rises significantly, as the educational level rises according to the calculations. Income factors are also found to be effective on the income distribution for the years 1987 and 1994. According to the Shorrocks decomposition analysis made by TUSIAD (2000), entrepreneurial income is found to have the most influence on income inequality in the years 1987 and 1994. Interest income is not one of the crucial factors of inequality for the year 1987. However, the interest income is found to affect income inequality almost as much as entrepreneurial income in 1994. The reason for that could be the specific conditions of economic crisis that Turkey experienced in the year 1994. As a consequence of the increase in income share of interest income, the Gini coefficient has risen from 0.43 in 1987 , to 0.49 in 1994.

In the TUSIAD(2000) study, the structure of inequality is also compared with the OECD countries including France, Germany, Italy and Scandinavian countries by using studies done for the OECD countries. The results show that unlike in Turkey, the main reason for the inequality in many of the OECD countries is the inequality within wages. The results also show that taxes and transfer payments has a significant effect on the reduction of the inequality in the OECD countries. When the impact of taxes and transfer payments are excluded, the inequality in Turkey is similar to the inequalities of welfare countries like Sweden, Denmark and Germany. However, when the taxes and transfer payments are included the inequality in these countries decline dramatically; where as the inequality in Turkey on shows a moderate $5.7 \%$ decline. These estimations show that the social policies targeting the reduction of inequality are very inefficient in Turkey compared to many OECD countries. 
There are also a number of studies that show the relationship between functional income distribution and trade flows in Turkey. These studies report a finding that the increases in trade flows have a disequalizing impact, by causing declines in the wage shares and rises in the mark-up rates. An empirical study shows Turkey's trade liberalization and export promotion policies that are implemented after 1980's, generated strong impacts on functional income distribution in Turkey (Boratav, Yeldan and Köse, 2000). For estimating the changes in the share of wages in manufacturing, a competitiveness index (CI) is formed, which is defined by [labor productivity*real exchange rate/real wages]. The changes between the years 19811997 are examined and for examining the changes the liberalization era is divided into four periods regarding the conditions of period. As a result, a strong correlation is found between export shares and competitiveness level. The estimations show that in the periods that exports/GNP has risen, the competitiveness level also has raised and in the periods that exports/GNP has declined, the competitiveness level also has declined. These results prove that increase in export share has caused declines in wage shares in manufacturing industry in the period of 1981-1997.

Onaran (2007b) also shows that increase in trade flows generated a negative effect on wage shares in the manufacturing industry in Turkey. Here the impact of globalization on Korea, Mexico and Turkey's functional income distribution are compared for the period 1972-2003. For showing the effect of trade flows on distribution a model is developed that aims at showing a correlation between wage shares and exports and imports. The model is developed in the following form:

$$
\begin{aligned}
& \Delta w s_{t}=b_{0}+b_{1 i} \sum=0,1 \Delta y_{t-i}+b_{2 i} \sum=0,1 \Delta x_{t-i}+b_{3} \Delta w s_{t-1}+b_{4} \Delta \exp _{t}+b_{5} \Delta i m p_{t}+b_{6} w s_{t-1} \\
& +b_{7} \exp _{t-1}+b_{8} i m p_{t-1}
\end{aligned}
$$

Export/Value Added(exp) and Import/Value Added(imp) ratios are used to test the effects of openness on the changes on wage share(ws). Using a lag is found to be convenient, since it can be argued that the changes in openness would effect distribution only with a time lag. For understanding whether the wage share has a pro or counter-cyclical pattern meaning whether productivity gains are reflected to wages or not, the effect of change in value added is observed. The lag of the wage share is used for observing whether a distributional shock is persistent. For capturing the 
effect of currency crisis and unexpected inflation generated by unexpected depreciation, the value of exchange rate is used in the model. Also a slope and intercept dummy on crisis is also added, since a recession could cause a change in the cyclical pattern of the wage share.

The results show that the trade flows do not cause a significant change in the wage shares of selected countries concurrently, as the coefficients on current export and import variables are not found to be statistically significant. However, the effect of one year lagged export/value added ratio on change in wage share is significantly negative for Turkey and Mexico. These results show that increase in export/value added ratio in manufacturing industry has resulted with a significant decline in wage share in the long-run both in Turkey and Mexico; whereas no significant relation between wage share and exports share is found for Korea. This estimation shows that the increased global pressure affects workers in industry negatively, in the absence of a trade policy based on industrial policy priorities and incomes policy. Hence, the workers in Mexico and Turkey are negatively affected from the increase in trade flows, because of the absence of a trade policy based on industrial policy priorities and incomes policy. Whereas in Korea, the presence of policies insulates workers from the negative effects of openness on wages.

Another study made by Metin-Özcan, Voyvoda and Yeldan (2000) examines the impact of trade flows on mark-up rates in the manufacturing sector by using a panel data. The relationship in distribution in this model is shown in below:

$$
M R_{i t}=\alpha_{i}+\beta_{1} O_{i t}+\beta_{2} C R 4_{i t}+\beta_{3} R W_{i t}
$$

$M R_{i t}$ shows the sectoral mark-up rates that are described as (value added)/(cost of intermediate goods + cost of wages); $O_{i t}$ shows the openness (ratio of imports plus exports to the value added); $C R 4_{i t}$ shows the concentration ratio and $R W_{i t}$ shows the real wage expenditures. $i$ gives the sectoral codes and $t$ consists of the years between 1980-1996. Firstly, the analysis is made by using 29 sub-sectors of manufacturing based on 3 digit ISI-Classification (rev.2) and the following equation is estimated:

$$
M R_{i t}=a_{i}-0.004 O_{i t}+0.181 C R 4_{i t}+0.111 R W_{i t}
$$

$$
(-5.107) \quad(6.361) \quad(13.108)
$$


According to the findings of this study, the mark-up rates are found to have a positive correlation with the real wages. The positive correlation between the markup rates and the real wages proves that the shocks in wages could be tolerated in the manufacturing industry. The mark-up rates and the concentration ratio are also found to have a positive relation, which is consistent with the theories of the Kaleckian school.

The overall coefficient of openness is found as -0.004 . Thus, the trade liberalization is found to have almost no effect on the mark-up rates. For estimating the relationship between openness and the mark-up rates, another equation is estimated by using the subgroups that experienced trade liberalization after 1980:

$$
M R_{i t}=a_{i}+0.026 O_{i t}+0.091 C R 4_{i t}+0.076 R W_{i t}
$$

$$
(-5.107) \quad(6.361)
$$

The sectors that had a trade ratio below 50\% in the year 1980 are defined as "inwardoriented". Amongst these sectors, the sectors that had a trade ratio above 50\% in the year 1996 are assumed to become "open". Hence, the sectors that experienced trade liberalization are determined. According to the results of this equation, the mark-up rates in the sectors that experienced trade liberalization are affected positively from the increases in the trade flows. This result is inconsistent with the expectations of the Stolper-Samuelson theory. Since, the trade flows have a positive correlation with the mark-up rates; the share of entrepreneurs rise and the functional income distribution is affected negatively from the trade flows.

Onaran and Yentürk (2003) also examine the impact of trade liberalization on the mark-up rates in Turkey by using a panel regression. In the analysis the changes in 26 sectors for the sub-periods 1980-1988 and 1989-1993 is tested by the following equation:

$k_{i t}=\alpha_{i}+\delta_{t}+a_{1} * \ln r e r_{i t}+a_{2} * X Q_{i t}+a_{3} * M C_{i t}+a_{4} * \ln Q_{i t}$

The period of 1989-1993 is separated from 1980-1989, since it is a period that the wage reducing effects of the 1980's is slightly recovered between the years 19891993. For estimating the reasons behind changes in the mark-up rates $(k)$, the real 
exchange rates (rer), export intensity $(X Q)$, import intensity $(M C)$, output $(Q)$ and $\operatorname{sectoral}(\alpha)$ and yearly $(\delta)$ dummies are used. The mark-up rates are defined by value added over total costs, export intensity is defined by exports over domestic production and import intensity is defined by imports over domestic consumption in the selected sectors. According to the estimations of the regression the export intensities are found to be insignificant for both of the sub-period selected. Only the import intensity in the 1989-1993 period is found to have a negative impact on the mark-up rates, which is explained by reduction of competitiveness that is caused by the appreciation of TL.

Also the relationship between profit margins, non-wage costs and wage costs is also analyzed in the study. A clear trade-off between non-wage costs and wage costs is graphically shown. The real exchange rate $(\mathrm{TL} / \$)$ is expected to have an important role in this trade-off by effecting the non-wage costs. The firms choose to reduce the real wage costs for maintaining the same level of profit margins, as an appreciation in the TL rises the amount of non-labor cost when the prices are constant. Also the impact of real exchange rate on the mark-up rates is examined by the regression used. According to the regression, the increase in the real exchange rate (TL/\$) also have a negative impact on the mark-up rates by rising the amounts of costs.

In this section, the impact of trade flows on inequality is discussed by using a theoretical and empirical framework. The studies on the income distribution usually focus on the individual, functional inequality and the inequality within wages. The empirical studies made usually show the negative impact of trade flows on inequality in the developing countries. This result is consistent with the theories of the political economy literature, rather than the extensions of the Stolper-Samuelson theorem. 


\section{AN ANALYSIS OF INCOME INEQUALITY INDICATORS IN THE POST 1980 PERIOD IN TURKEY}

In this section, the income distribution in Turkey is examined by using different indicators. The changes in the individual and functional income distribution are shown and the relationship between globalization and changes in inequality are analyzed by examining the structure of income inequality. The reliability of income distribution data is questioned by making comparisons between different sources of data.

\subsection{An overview of inequality measures}

Inequality has been measured from several different perspectives and by using various measures including the Gini coefficient, mean log deviation, squared coefficient of variation, the Theil index and the Atkinson index. In this study, individual income distribution will be measured by the Gini coefficient. The Gini coefficient is defined as one-half of the relative mean difference, which is the arithmetic average of the absolute values of differences between all pairs of incomes.

$$
G=\frac{1}{2 n^{2} \mu} \sum_{i=1}^{n} \sum_{j=1}^{n}\left|Y_{i}-Y_{j}\right|
$$

The Gini coefficient concerns the independency of scale condition and the PigouDalton condition. According to the Pigou-Dalton condition, a transfer from a richer to a poorer person always reduces the Gini coefficient. Transfers between middle income individuals affect the Gini coefficient less compared to transfers between high and low income individuals (Sen, 1997). 
The squared coefficient of variation is another method that is used for estimating inequality (Cowell, 1995). In the squared coefficient of variation method, relative variance is used for measuring inequality. The relative variance is found by dividing variance by the aritmetic mean:

$S C V=\sum_{i=1}^{n}\left(Y_{i}-\mu\right)^{2} / n \mu$

Squared coefficient of variation does not have a limit like the Gini coefficient. As the value of SCV increases the inequality is considered as increasing.

The Theil index is another index that is used for measuring inequality. The Theil index is usually used for comparing the income distribution in different countries (Sen, 1997). The Theil index could also be prefered, since the decomposition of Theil index into its various sources is easier compared to the decomposition of the Gini coefficient. Theil index could be calculated by the following formula:

$$
T=\left[\sum_{i=1}^{n} \frac{Y_{i}}{\mu} \log \left(\frac{Y_{i}}{\mu}\right)\right] / n
$$

The distribution of income between income factors like profit, wages and rent is measured by using functional income distribution. According to the classical school economists income distribution is also a part of the relations between social classes. Thus, the distribution of income sources determines the income distribution between classes. Therefore, functional income distribution is critical in explaining the reasons that effect individual income distribution (TUSIAD, 2000). In this study, the factors that affect functional income distribution and the affect of functional income distribution on individual income distribution will also be examined.

There are a number of ways of measuring the impact of different income sources on distributional inequality. Shorrocks decomposition analysis is one of the methods that is used for decomposing inequality for estimating the impact of different income factors in inequality. Shorrocks decomposition analysis decomposes the inequality for the inequality estimated by the squared coefficient of variation method. In this decomposition method, Shorrocks assumes that the impact of the income factors that are equally distributed is zero. Thus it is assumed that, if all individuals gain same 
amount of income from an income factor, then the existence of the income factor will not affect the inequality. The equation used in Shorrocks decomposition analysis is shown below (Shorrocks, 1982):

$s_{k}=\operatorname{cov}\left(Y, Y_{k}\right) / \sigma^{2}(Y)$

$k=$ income factor

$s_{k}=$ the effect on inequality of factor $\mathrm{k}$

$Y=$ total income

$Y_{k}=$ income gained from factor $\mathrm{k}$

In this equation $\operatorname{cov}\left(Y, Y_{k}\right)$ could be separated into two components:

$\operatorname{cov}\left(Y, Y_{k}\right)=\left(C_{A}^{k}+C_{B}^{k}\right) / 2$

$C_{A}^{k}=\sigma^{2}\left(Y_{k}\right)$

$C_{B}^{k}=\sigma^{2}(Y)-\sigma^{2}\left(Y-Y_{k}\right)$

In this equation the $C_{A}{ }^{k}$ coefficient measures the within inequality of income factor k. $C_{B}{ }^{k}$ coefficient measures the difference between the income inequalities calculated with and without considering the income factor $k$ in the total income. Hence, the contribution of income factor $k$ is regarded as the inequality which would be observed when income factor $k$ is the only source of income; plus the fall in income inequality, when the income factor $k$ is removed.

\subsection{Estimation of income distribution data}

For examining the extent of income distribution in Turkey, the outcomes of Household Income Surveys and national income accounts data is used in this study. Turkish Statistical Institute (Turkstat) is the institution that makes Household Income and annual Manufacturing Industry Surveys and calculates data for national account. The outcomes of Household Income Surveys are crucial for exploring the extent income inequality, functional income distribution and inequalities within income types. National account data will be used for mainly explaining functional income distribution. 
Household Income Surveys refer to the surveys which consist of the consumption structures and income levels of the households and individuals with respect to the socio-economic groups, rural, urban areas and regions. A sample of households is surveyed for obtaining data (Table-4.1) and estimations on income levels are made using data obtained. The latest Household Income Survey before 2002, was conducted in the year 1994. Therefore, detailed income distribution statistics are missing between the years 1995-2001. In 2002, Household Income Survey has started to be made annually and the outcomes of surveys related to income distribution are declared for the years 2002, 2003, 2004 and 2005.

Gini coefficient is calculated by Turkstat by using data of Household Income Surveys. Distribution of income between households is used for drawing the Lorenz curve and calculating the Gini coefficient. Income factor shares are also estimated by using the outcomes of Household Income Surveys. The factor shares are calculated by using the types of income received by household members.

Table-4.1: Number of households and household members surveyed

\begin{tabular}{|l|l|l|l|l|l|}
\hline & $\mathbf{1 9 9 4}$ & $\mathbf{2 0 0 2}$ & $\mathbf{2 0 0 3}$ & $\mathbf{2 0 0 4}$ & $\mathbf{2 0 0 5}$ \\
\hline Number of Household & & & & & \\
Members & 118,522 & 32,767 & 107,614 & 35,388 & 35,498 \\
Number of Households & 26,236 & 7,734 & 25,920 & 8,640 & 8,640 \\
\hline
\end{tabular}

Source: Turkstat 1994, 2002-2005 Household Income Surveys

According to the Household Income data, the income factors were divided to different income sources for estimating the functional income distribution. In this study, the wages and salaries factor in the functional income distribution statistics both contain wages monthly and daily wages. The entrepreneurial income could be described as the income that entrepreneurs gain from their work. The entrepreneurial income is divided into three components for this study: agricultural, employer, selfemployed. The agricultural entrepreneurial income is the income that entrepreneurs gain from the agricultural activities. The entrepreneurial income of the self-employed and employees are also examined in different categories for observing the income distribution amongst different social classes in a better way. The securities income factor contains income gained from financial assets. The real estate income contains the rental income gained from the individual's real estates and the transfer payments factor contains aids, pensions and scholarships that individuals get. 
For estimating the wage shares from the national income accounts data, the GDP statistics calculated by production and income methods are used. These data are available at the database of the website of the Turkstat: www.tuik.gov.tr. The GDP calculated by production statistics are estimated in the process of calculating the GDP. However, since the GDP is not calculated by the income method, the wage payments component is estimated by Turkstat by using a number of statistics.

The wage payments are gross wage payments containing social security payments, bonuses and premiums. The wage payments are calculated in different sectors according to the different statistics. For the wage payments in manufacturing industry, electricity production and mining annual SIS statistics and Turkish Electricity Institute statistics are used. The amount of social security payments are gathered from the social security institutes. The wages in the construction sector are estimated in the process of calculating output by production. The output value in construction contains the wage payments; thus, the wage payments are already calculated while calculating the contribution of construction in GDP. The wage and salary payments of the government employees are gathered from the GDP statistics calculated by the method of production and consumption. The wages in the agriculture are predicted by using 1985 input-output tables. By using the average wage and number of workers data taken from the Household Labor Force surveys the changes in the wage in the agriculture are predicted. In these predictions 1985 is taken as the base year. For the estimation of wages in trade, annual SIS statistics and statistics taken from social security institutes are used. While predicting the changes in the last years' wages, the minimum wages statistics are also used. For the estimation of the wages working in financial institutes the income-cost tables of the financial institutes are used.

\section{3. The structure of inequality in Turkey}

Turkey started to execute neoliberal policies including reduction in international trade barriers in the post 1980 period. The influence of trade liberalization has been examined more widely in the post 1990 period, especially after the economic crisis in 2001. However, despite the neoliberal policies implemented, the officially reported Gini coefficient declined from 0.44 to 0.38 between the years 2002-2005(Table-4.2), 
This value is also far lower than the Gini coefficient of 1994 that is found as 0.49 . In the longer term perspective the estimations of different studies show that the household income distribution in Turkey has followed a declining path from the 1960's onwards continuing throughout the post-1980 period of economic liberalization. The increase in the Gini coefficient from 1987 to 1994 is the only exception to this trend and this can be explained with the influence of the economic crisis that Turkey experienced in 1994 (TUSIAD, 2000). The estimations show that the decline in the Gini coefficient for the rural areas is clearly more compared to the decline for the urban areas. This decline in the rural Gini coefficient might be very effective on the decline in overall Gini coefficient

Table-4.2: Gini Coefficients in Turkey

\begin{tabular}{|c|c|c|c|c|c|c|c|c|c|c|c|}
\hline & 1963 & 1968 & $1973^{*}$ & 1978 & 1983 & 1987 & 1994 & 2002 & 2003 & 2004 & 2005 \\
\hline $\begin{array}{c}\text { Gini } \\
\text { Coefficient(Total) }\end{array}$ & 0.55 & 0.56 & 0.50 & 0.51 & 0.52 & 0.43 & 0.49 & 0.44 & 0.42 & 0.40 & 0.38 \\
\hline $\begin{array}{c}\text { Gini } \\
\text { Coefficient(Urban) }\end{array}$ & - & 0.40 & 0.45 & 0.43 & 0.45 & 0.44 & 0.51 & 0.44 & 0.42 & 0.39 & 0.38 \\
\hline $\begin{array}{c}\text { Gini } \\
\text { Coefficient(Rural) }\end{array}$ & - & 0.59 & 0.56 & 0.57 & 0.57 & 0.42 & 0.41 & 0.42 & 0.39 & 0.37 & 0.37 \\
\hline
\end{tabular}

Sources :

1963 - Çavuşoğlu, T., and Y. Hamurdan(1966), Gelir Dağılımı Araştırması 1963, SPO, Ankara.

1968 - Bulutay,T., Timur,S.and Ersel,H.(1971),Türkiye'de Gelir Dağılımı, Ankara:SBF.

1973 - SPO (1976), Gelir Dağılımı 1973, Ankara

1978- Celasun,M.(1986),'Income Distribution and Domestic Terms of Trade in Turkey, 1978-1983”, METU studies in development ,13,issue 12.

1983 - Celasun,M.(1986),'Income Distribution and Domestic Terms of Trade in Turkey, 1978-1983”, METU studies in development ,13,issue 12.

1987 - SIS(1990), 1987 Hanehalkı Gelir ve Tüketim Harcamaları Dağılımı Sonuçları, Ankara 1994 - SIS(1996), 1994 Hanehalkı Dağılımı Anketi Sonuçları, Ankara

2002, 2003, 2004, 2005 - TURKSTAT, Household Income Distribution Statistics (www.tuik.gov.tr)

*The rural Gini coefficient represents the Gini coefficient for the villages that have a population lower than 2000 and the urban Gini coefficient represents the Gini coefficient for the cities that have a population higher than 50000 .

Changes in functional income distribution could be one of the crucial factors of reduction of inequality statistics. Therefore, for explaining the decline in the Gini coefficient, changes in functional income distribution has to be examined. According to the household income distribution statistics, between the years 1994-2002 the share of wages and salaries in total income has raised from $30.0 \%$ to $38.8 \%$ and between the years 2002-2005, the share of wages and salaries in total income has risen from $38.8 \%$ to $42.5 \%$ (Table-4.3). In the year 1994, Turkey experienced a severe economic crisis that resulted with a huge decline in the real wages. Thus, the wage share is lower in the year of economic crisis, 1994 compared to the further 
years. The increase of wage share after 2002, could also be explained by the reduction in influence of the 2001 economic crisis on wage shares. After 2002, as the effects of economic crisis were reduced, the wage share might be increased according to the household income distribution data. Thus, the estimations of Household Income data can be misleading due to the specific choice of the 1994 and 2002 which are years that the negative distributional impact of the economic crises are observed.

Parallel to increase in income shares of wages and salaries, the share of employer's entrepreneurial income in total income has declined to $11.7 \%$ from $15.2 \%$ between the years 1994-2002 and has declined to $9.4 \%$ from $11.7 \%$ between the years 2002 2005 (Table-4.3). In this study employer's entrepreneurial income is found by considering the income of employers in services and industry. The agricultural entrepreneurial income is defined as a separate income type. Therefore, the income share of employers' in services and industry are found to have declined.

With the effect of the decline in income share of employer's entrepreneurial income, the total entrepreneurial income including both employer and self-employed revenues decreased from $27.8 \%$ in 1994 to $19.3 \%$ in 2005. An income decomposition analysis made in this study for the year 1994 shows that the main reason for the inequality in Turkey is the inequalities in entrepreneurial income and interest income. This estimation shows that the structure of inequality in Turkey is very different from many other OECD countries. The Shorrocks decomposition calculations made for the OECD countries like Denmark, Finland, Germany, Italy, Holland and Sweden show that the inequality in wages is the main reason of total income inequality. These countries are mostly the countries that lower inequality rates are observed. However, in Turkey the inequality in entrepreneurial income is effective on income inequality rather than the inequality in wages. The main reason for this difference is that the share of wages is higher compared to Turkey in the OECD countries mentioned (TUSIAD, 2000).

Since contribution to the total inequality is highest for entrepreneurial income, the decline in entrepreneurial income's share might be one of the reasons of the decline in the Gini coefficient. In our study an income distribution analysis for the recent data will also be made for understanding the reasons behind income inequality. 
Table-4.3: The share of income factors in total income (\%)

\begin{tabular}{|l|c|c|c|c|c|}
\hline & $\mathbf{1 9 9 4}^{\boldsymbol{*}}$ & $\mathbf{2 0 0 2}$ & $\mathbf{2 0 0 3}$ & $\mathbf{2 0 0 4}$ & $\mathbf{2 0 0 5}$ \\
\hline Entrepreneural Income & $\mathbf{2 7 . 8}$ & $\mathbf{2 1 . 3}$ & $\mathbf{2 2 . 2}$ & $\mathbf{2 2 . 4}$ & 19.3 \\
\hline (i)Entrepreneural Income (employer) & 15.2 & 11.7 & 12.6 & 11.4 & 9.4 \\
\hline (ii)Entrepreneural Income (self-employed) & 12.6 & 9.6 & 9.6 & 11.1 & 9.8 \\
\hline Agricultural Entrepreneural Income & 18.0 & 13.2 & 9.9 & 9.4 & 9.6 \\
\hline Real Estate Income & 4.6 & 4.1 & 3.6 & 2.7 & 2.9 \\
\hline Securities & 8.3 & 5.1 & 2.6 & 2.2 & 2.7 \\
\hline Transfer Payments & 10.8 & 17.5 & 20.0 & 21.2 & 23.1 \\
\hline Wages and Salaries & 30.5 & 38.8 & 41.8 & 42.2 & 42.5 \\
\hline
\end{tabular}

Source: TURKSTAT, Household Income Distribution Statistics (www.tuik.gov.tr), the author's own calculations

* The shares of the year 1994 are recalculated without considering predicted rent incomes for the purpose of making the statistics compatible with the other years.

Neither the declining Gini coefficient nor the income distribution statistics which indicate an increasing path for the share of wages in total income seem to suggest that the post-1980 economic liberalization did not necessarily produce inequality rising effect that the political economy literature claims. However, the results of the other distribution statistics are not totally inconsistent with claim that globalization will result in reduction of wage shares. Both national income accounts (Table-4.4) and manufacturing industry statistics (Figure-1.4) indicate a falling wage share from 1994 to 2002 and between the years 2002-2005 in industry. Hence while the share of wages in total income can be on a slightly increasing trend, when the data is disaggregated by sector of economic activity, we observe that the trends of wage share are quite distinct.

The industry sector in which tradable goods is produced are more open to the influence of rising global competitiveness and labor flexibility; since either a part of tradable good could be outsourced or the whole tradable good could be produced in a country with cheaper labor. Therefore, the effect of trade liberalization on wages could be expected to be more in the industry sectors where tradables are produced. According to the national income accounts data, the wage shares in industry has declined from a peak of $34 \%$ in 1991 to $21.6 \%$ in 2005(Table-4.4). These statistics show that the wage shares in the manufacturing industry declined severely between the years 1991-2005. 
Table-4.4: Wage shares calculated from the National Income Accounts (\%)

\begin{tabular}{|c|c|c|c|c|}
\hline & \multicolumn{3}{|c|}{ Wage Shares } & \\
\hline & Agriculture & Industry & $\begin{array}{c}\text { Services(private } \\
\text { sector) }\end{array}$ & $\begin{array}{c}\text { Total } \\
\text { Wages/GDP }^{*}\end{array}$ \\
\hline $\mathbf{1 9 8 7}$ & 9.2 & 20.0 & 17.9 & $\mathbf{2 0 . 7}$ \\
\hline $\mathbf{1 9 8 8}$ & 11.3 & 19.0 & 19.3 & $\mathbf{2 1 . 5}$ \\
\hline $\mathbf{1 9 8 9}$ & 8.5 & 22.6 & 19.8 & $\mathbf{2 4 . 0}$ \\
\hline $\mathbf{1 9 9 0}$ & 9.0 & 27.2 & 21.7 & $\mathbf{2 7 . 2}$ \\
\hline $\mathbf{1 9 9 1}$ & 10.3 & 34.0 & 24.8 & $\mathbf{3 1 . 9}$ \\
\hline $\mathbf{1 9 9 2}$ & 12.4 & 32.9 & 23.9 & $\mathbf{3 1 . 7}$ \\
\hline $\mathbf{1 9 9 3}$ & 11.6 & 32.4 & 23.2 & $\mathbf{3 0 . 9}$ \\
\hline $\mathbf{1 9 9 4}$ & 8.2 & 24.4 & 19.2 & $\mathbf{2 5 . 5}$ \\
\hline $\mathbf{1 9 9 5}$ & 8.3 & 20.8 & 15.9 & $\mathbf{2 2 . 2}$ \\
\hline $\mathbf{1 9 9 6}$ & 9.8 & 20.9 & 18.5 & $\mathbf{2 3 . 9}$ \\
\hline $\mathbf{1 9 9 7}$ & 10.9 & 22.6 & 19.5 & $\mathbf{2 5 . 8}$ \\
\hline $\mathbf{1 9 9 8}$ & 7.8 & 25.2 & 18.9 & $\mathbf{2 5 . 5}$ \\
\hline $\mathbf{1 9 9 9}$ & 10.6 & 29.5 & 23.2 & $\mathbf{3 0 . 7}$ \\
\hline $\mathbf{2 0 0 0}$ & 8.7 & 29.5 & 22.9 & $\mathbf{2 9 . 2}$ \\
\hline $\mathbf{2 0 0 1}$ & 8.9 & 25.1 & 21.6 & $\mathbf{2 8 . 3}$ \\
\hline $\mathbf{2 0 0 2}$ & 9.8 & 23.5 & 18.6 & $\mathbf{2 6 . 3}$ \\
\hline $\mathbf{2 0 0 3}$ & 9.2 & 22.7 & 18.4 & $\mathbf{2 6 . 1}$ \\
\hline $\mathbf{2 0 0 4}$ & 9.8 & 22.3 & 19.5 & $\mathbf{2 6 . 3}$ \\
\hline $\mathbf{2 0 0 5}$ & 11.0 & 21.6 & 20.2 & $\mathbf{2 6 . 6}$ \\
\hline
\end{tabular}

Source: Turkstat (www.tuik.gov.tr) and the author's own calculations based on GDP by income and GDP by production data.

*Total Wages/GDP statistics are higher compared to wage share statistics for industry and private services, since wages in public services and voluntary activities are considered in this ratio.

However, in the services sector, in which nontradables are produced; the share of wages only declined from $24.8 \%$ to $20.2 \%$ between years 1991-2005 (Table-4.4). Since replacing a worker with a worker abroad is much harder in services, the increasing trade flows has not affected wage shares in services very negatively. Therefore, the wages in services sectors including trade and construction are not being affected from global competition and threat of capital mobility as much as sectors in which tradable products are produced. For this reason, only a slight decline in the wage shares in services is observed for the years 1991-2005.

\section{4 .4. Problems in estimations of inequality}

As mentioned above in discussion of Table 4.3, the main reason for the decline in the Gini coefficient can be predicted as the decline in the share of entrepreneurial income and the rise in the share of wages. However, this result could be not be reliable, since there are inconsistencies observed between national income accounts and households 
income distribution data. According to the national accounts statistics, although the share of compensation of employees rose in the sectors like services where nontradable goods are produced, the share of compensation of employees has not changed significantly between years 1994-2002 (Table-4.4).

The results of national accounts data are different from the household income data that are calculated from the household income surveys. The inconsistencies between household income data and national income accounts bring some doubts on the relevance of the income distribution statistics. In this section, the extent of inconsistencies between national accounts data and household income surveys are analyzed. The reasons behind the inconsistencies are analyzed and finally the reliability on the decline in the Gini coefficient statistics is questioned.

Inconsistencies between household income data and national income accounts are seen in many developing countries. Household income statistics are usually found to underestimate the total income or expenditure, when statistics are compared to the national accounts. By using a data set for 88 developing countries, Ravallion (2003) compares the private consumption expenditures in the national accounts with the household incomes or expenditures that are estimated from budget surveys. Ravallion (2003) calculates that household income statistics estimates only a part of total income in national income accounts. The median of the ratio of total income or expenditure in household income statistics to total income or expenditure in national accounts is estimated as 0.768 . This ratio is significantly lower than unity in Eastern Europe/Central Asia(EECA), Latin America and South Asia. The ratio is also significantly lower for the countries that prefer income surveys rather than expenditure surveys. Furthermore, only $51.9 \%$ of growth rates are captured by household income statistics.

Household surveys might underestimate income and expenditure due to several reasons (Ravallion, 2003). First of all, individuals in high income groups might refuse to participate in the survey or reaching individuals in high income groups for making a survey might be harder. Secondly, interview respondents can forget or prefer not to declare a part of their consumption or income sources. Amongst survey specialists, incomplete declaration is considered as a greater problem for income surveys compared to the expenditure surveys. The survey design also has an impact 
on underestimation. Shorter survey questionnaires could be expected to produce greater bias.

In Turkey, the income distribution is estimated by surveys considering income and expenditure at the same time. Inconsistencies between household income data and national income accounts are also seen in Turkey. According to Bulutay (2005) the incomplete declaration that employers made in household income surveys could be the reason of this inconsistency. Bulutay estimates that the wage shares calculated in Household Income surveys is unrealistically high. The share of wages and salaries in total income is $47.0 \%$ in 2002 and $52.2 \%$ in 2003, when transfer income is excluded.

The household income data and national accounts could be compared by using the operating surplus and employee payments that are calculated by Turkstat in GDP by income method statistics. Operating surplus is considered as the sum of entrepreneurial and property incomes. In GDP calculated by income method statistics, operating surplus and employee payments are predicted by using Turkstat household labor force surveys, sectoral statistics, social security statistics and changes in minimum wages. These statistics could be compared with the statistics that come from household income surveys.

Table-4.5 - Differences between national accounts and income distribution data (million YTL)

\begin{tabular}{|l|c|c|c|c|c|}
\hline & $\mathbf{1 9 9 4}$ & $\mathbf{2 0 0 2}$ & $\mathbf{2 0 0 3}$ & $\mathbf{2 0 0 4}$ & $\mathbf{2 0 0 5}$ \\
\hline $\begin{array}{l}\text { (1)Operating surplus according to } \\
\text { national income accounts data }\end{array}$ & 2286 & 138,723 & 179,960 & 214,252 & 238,888 \\
\hline $\begin{array}{l}\text { (2)Entrepreneurial + Property } \\
\text { income according to household } \\
\text { income surveys data }\end{array}$ & 1174 & 58,362 & 61,889 & 71,786 & 78,541 \\
\hline $\begin{array}{l}\text { (3) Employee payments according } \\
\text { to national income accounts data }\end{array}$ & 988 & 72,924 & 93,978 & 113,261 & 129,714 \\
\hline $\begin{array}{l}\text { (4) Wages and Salaries income } \\
\text { according to households income } \\
\text { surveys data }\end{array}$ & 625 & 51,753 & 67,603 & 82,573 & 96,967 \\
\hline (2)/(1) (\%) & 51.35 & 42.07 & 34.39 & 33.51 & 32.88 \\
\hline $\mathbf{( 4 ) / ( 3 ) ( \% )}$ & 63.27 & 70.97 & 71.93 & 72.9 & 74.75 \\
\hline $\mathbf{( 3 ) / ( 1 ) ( \% )}$ & 43.22 & 52.57 & 52.22 & 52.86 & 54.30 \\
\hline $\mathbf{( 4 ) / ( 2 ) ( \% )}$ & 53.24 & 88.68 & 109.23 & 115.03 & 123.46 \\
\hline
\end{tabular}

Source: Turkstat (www.tuik.gov.tr) and the author's own calculations 
In 2005, the total entrepreneurial and property income that comes from income distribution surveys is 78.5 billion YTL, which is only $32.8 \%$ of the operating surplus value that is calculated from national accounts calculated by the income method. This statistic proves that employers declared their revenues lower in income surveys. The ratio of the total entrepreneurial and property income to the operating surplus value is estimated as $\% 51.35$ for $1994,42.07 \%$ for 2002 and $32.8 \%$ for 2005 (Table -4.5$)$. These statistics show that the underestimation problem for the total entrepreneurial and property income has been increasing each year.

Employee income statistics of household income distribution data are more consistent with national accounts compared to employer and self-employed income statistics. In 2005, the total amount of revenue that employees gained was 97.0 billion YTL, which is $74.75 \%$ of the employee payments that is calculated from national accounts. The ratio of employee income in income distribution statistics to employee payments in national accounts also rose from $63.24 \%$ to $74.75 \%$ between years 1994-2005. Also, between years 1994-2005 according to the national accounts data the ratio between the employee payments to operating surplus show a relatively slight increase. However, according to the household income distribution data the ratio of wages income to total entrepreneurial and property income shows a dramatic rise from $53.24 \%$ in 1994 to $123.46 \%$ in 2005 .

These estimations show that the income inequality in Turkey might be higher than the Gini coefficient calculations show. The decline in Gini coefficient is attributed to the severe decline in the share of entrepreneurial income and the parallel increase in wage shares. However, the national account statistics show that an increasing portion of wages and a declining portion of entrepreneurial and property income are estimated by household income statistics. Also as Table 4.5 indicates, the ratio of employee compensation to the entrepreneurial and property income is increasing slightly according to the national accounts data; yet according to household income survey data, the same ratio shows a dramatic rise.

\section{5. Decomposition of income sources}

Functional income distribution can be considered as one of the key factors that explains income distribution. The changes within and between income sources could 
significantly effect income inequality. In this section, Shorrocks decomposition analysis will be used for exploring the contribution of income sources (entrepreneurial income, agricultural income, wages, securities, transfer payments, rental income) to inequality. The effects of changes in shares of income factors and inequalities within income factors will be estimated for the years 1994, 2002-2005 using the household income survey data taken from Turkstat.

The estimations of the Shorrocks decomposition analysis is given in the Table 4.6. In the table, [a] shows the results of the analysis, which shows the effects of income factors on inequality according to the Shorrocks decomposition $\left(s_{k}\right)$. [b] stands for showing the shares of income factors in total income. [c] is a term estimated by dividing [a] to [b] for examining the relative inequalities within the income factors.

For the years 1994 and 2002, securities income is calculated as one of the crucial factors of inequality according to the estimations of Shorrocks income decomposition analysis, accounting for 38.3\% in 1994 and 20.6\% in 2002 (Table 4.6). For these years, not only the factor shares of securities income are high compared to following years, but also the relative inequality of securities income is much substantial than the relative inequality of other income sources: 4.6 in 1994 and 4.0 in 2002. The possible reason of these results is the influences of 1994 and 2001 economic crisis that occurred with the impact of capital outflows. During the year 2001, with the effect of the crisis the real interest rates have reached to the level of $70 \%$. As the influence of the 2001 economic crisis has started to reduce, the interest rates got into a declining path. The real interest rates declined from $48.6 \%$ to $27.2 \%$ between the years 2002-2003. As a result, the contribution of securities income on inequality has decreased from $20.64 \%$ in 2002 to $7.1 \%$ in 2003 . According to the calculations made for this study, the decrease in the shares of dividends and interest revenues gained from bank accounts are the main reasons of this decline.

The huge reduction in the influence of securities income in inequality could be considered one of the most important factors of reduction of Gini coefficient from 2002 to 2003. A similar process is observed after the economic crisis 1994. The contribution of securities income on total income is found as $38.3 \%$, which is also makes securities income one of the main unequalizing income sources. 
Table 4.6 - Shorrocks Income Decomposition Analysis

\begin{tabular}{|c|l|c|c|c|c|c|}
\hline \multicolumn{1}{|c|}{} & 1994 & 2002 & 2003 & 2004 & 2005 \\
\hline \multirow{5}{*}{ [a] } & Entrepreneural Income & 48.7 & 37.8 & 43.7 & 49.0 & 44.2 \\
& (i)Entrepreneural Income (employer) & 43.8 & 31.6 & 36.8 & 35.1 & 33.4 \\
& (ii)Entrepreneural Income (self-employed) & 4.9 & 6.2 & 6.9 & 13.9 & 10.8 \\
& Agricultural Entrepreneural Income & 3.9 & 3.2 & 9.5 & 9.3 & 8.8 \\
& Real Estate Income & 2.2 & 6.6 & 5.8 & 3.0 & 3.2 \\
& Securities & 38.3 & 20.6 & 7.1 & 2.8 & 4.9 \\
& Transfer Payments & 1.8 & 5.2 & 7.7 & 8.8 & 10.8 \\
& Wages and Salaries & 5.1 & 22.9 & 25.3 & 25.5 & 26.8 \\
\hline \multirow{5}{*}{ [b] } & Entrepreneural Income & 27.8 & 21.3 & 22.2 & 22.4 & 19.3 \\
& (i)Entrepreneural Income (employer) & 15.2 & 11.7 & 12.6 & 11.4 & 9.4 \\
& (ii)Entrepreneural Income (self-employed) & 12.6 & 9.6 & 9.6 & 11.1 & 9.8 \\
& Agricultural Entrepreneural Income & 18.0 & 13.2 & 9.9 & 9.4 & 9.6 \\
& Real Estate Income & 4.6 & 4.1 & 3.6 & 2.7 & 2.9 \\
& Securities & 8.3 & 5.1 & 2.6 & 2.2 & 2.7 \\
& Transfer Payments & 10.8 & 17.5 & 20.0 & 21.2 & 23.1 \\
& Wages and Salaries & 30.5 & 38.8 & 41.8 & 42.2 & 42.5 \\
\hline \multirow{6}{*}{ [c] } & Entrepreneural Income & 1.8 & 1.8 & 2.0 & 2.2 & 2.3 \\
& (i)Entrepreneural Income (employer) & 2.9 & 2.7 & 2.9 & 3.1 & 3.5 \\
& (ii)Entrepreneural Income (self-employed) & 0.4 & 0.6 & 0.7 & 1.3 & 1.1 \\
& Agricultural Entrepreneural Income & 0.2 & 0.2 & 1.0 & 1.0 & 0.9 \\
& Real Estate Income & 0.5 & 1.6 & 1.6 & 1.1 & 1.1 \\
& Securities & 4.6 & 4.0 & 2.7 & 1.3 & 1.8 \\
& Transfer Payments & 0.2 & 0.3 & 0.4 & 0.4 & 0.5 \\
& Wages and Salaries & 0.2 & 0.6 & 0.6 & 0.6 & 0.6 \\
\hline
\end{tabular}

Source: The author's estimations calculated using Turkstat household income data

(a) Effects of income factors on inequality according to the Shorrocks decomposition $\left(s_{k}\right)(\%)$

(b) Shares of income factors in total income (\%)

(c) Relative inequality indicator $(\mathrm{a} / \mathrm{b})$

According to the Shorrocks income decomposition analysis of the years 1994, 20022005 entrepreneurial employer income is the most important reason for income inequality ranging from $48.7 \%$ in 1994 to $44.2 \%$ in 2005. Employers' entrepreneurial income has a negative effect on the income distribution, since the relative income inequality of entrepreneurial income of employers is much higher than other income factors. However, as the factor share of entrepreneurial income of employers declined from $15.2 \%$ to $9.4 \%$ (Table 4.6 , Section b), the effect of entrepreneurial income on inequality fell between years 1994 - 2005 from $43.8 \%$ to $33.4 \%$ (Table 4.6, Section a). Since disturbing effect on income distribution is found to be highest for entrepreneurial income, decline in entrepreneurial income could be considered as one of the important factors of reduction in the Gini coefficient. 
Between years 2002-2005, the effect of labor income is found to be higher than the effect of labor income in 1994 that was found as 5.1\%. This statistic shows between years 1994-2002, wages and salaries has become one of the important factors of the income inequality. There could be several reasons for the increase in the contribution of wages and salaries in total inequality. First of all, the share of wages and salaries increased severely between 1994 and 2002. Secondly, the relative income inequality within wages and salaries might have increased during 1994-2002.

The income distribution statistics show that the share of agricultural income had been falling between the years 1994-2005, possibly due to the decline in the share of rural population. A study in the World Economic Outlook (IMF, 2007a) estimates that the shift of labor to the non-agricultural sectors has a positive impact on inequality in the developing countries, since the shift of underemployed agriculture workers from agriculture to industry increase the relative productivity in agriculture. According to the income distribution studies made, the rural Gini coefficient declined from 0.57 to 0.42 between years 1983-87 in which high rates of immigration is observed in Turkey (Table 4.2). This could be due to the immigration of underemployed workers from rural to urban areas. Thus, the Gini coefficient for all individuals also declined from 0.52 to 0.43 in these years. Hence, the positive effect of the fall in the share of agricultural income and population on income distribution in Turkey could also be discussed. This result shows that the assumptions of Kuznets type theories cannot be considered as true in the case of developing countries. Kuznets type theories assume that labor shifts from agriculture to industry and services can increase income inequality, since inequality in agricultural income is assumed to be lower than inequality in labor income.

\section{6. Is the reported decline in the Gini coefficient for real?}

The fall in the Gini coefficient in the post-1980 period could be explained by several reasons that are mostly unrelated with the globalization process. A summary of possible accounts of what happened to inequality in Turkey since 1980's could be listed in below:

- The data error in the household income surveys which form the basis of Gini coefficient calculations could be effective on the decline in the Gini coefficient. The 
rising underestimation of entrepreneurial income in household income surveys combined with increasing estimation of wage income could result with a higher decline in the share of entrepreneurial income and a higher increase in wage shares than it is in reality.

- The existing times series data is interrupted and unfortunately the years of economic crises are chosen for the household income surveys. Both 1994 and 2002 are the years that the effects of economic crises are observed. Both in the years 1994 and 2002, high and volatile rates of interest are seen; which resulted with high rates of securities income and raising inequality in securities income. Also, the wage shares are lower in 1994 and 2002 compared to the previous years (Table - 4.4). The reason for that might also the possible effects of the economic crises. Inevitably, worsening of income distribution in crises is followed by a de facto improvement in the following years.

- The labor productivity of workers and self-employed in urban areas are higher compared to the labor productivity in rural areas. Hence, decline in the share of agricultural income that is caused by immigration could result with a reduction in inequality.

Hence, there a number of accounts for the decline in Gini coefficient in the post 1994 period caused by the reasons that are not related with either increasing trade and capital flows. In the industry sector where tradable goods are produced a decline in wage shares are observed both according to the national accounts (Table-4.4) and industry statistics (Figure- 2.4). Inequality is also found to be negatively correlated with the effect of economic crises caused by capital outflows and high amounts of capital outflows are seen due to the lower restrictions on capital account flows. These results show that the decline in Gini coefficient in the post 1994 period is not related with the increase in trade and capital flows and possibly occurred despite the unequalizing effects of globalization. 


\section{ANALYSIS OF WAGE SHARES BASED ON PANEL DATA}

In this section, an empirical analysis is made for examining the correlation between the trade flows and the share of wages in the manufacturing industry. The analysis focus on the wage shares in the manufacturing industry between years 1981-2001, for estimating the impact of trade flows in the post-liberalization period to the sectors where tradable goods are produced.

\section{1. Wage share}

In this section the impact of globalization on the functional income distribution in Turkey will be shown by examining the effects of trade flows on the wage shares in the manufacturing industry. For examining the impact of the post-liberalization period in Turkey, the period after 1980's being examined in our analysis. The effects of trade flows on wage shares in 22 manufacturing industry sectors will be investigated by using panel regression techniques for the years 1981-2001.

The wage share is given by the following equation:

$W S=\frac{W}{P R O D}=\frac{W^{*} L}{(T V A)}$

$W S=$ wage share

$W=$ wage per worker

$P R O D=$ labor productivity

$L=$ employment

$\mathrm{TVA}=$ total value added

The wage share(WS) is usually described as the ratio of total wages paid over total value added. Thus, the wage share could be considered as the portion of income that 
workers get from the income that is gained from production. Since the labor productivity gives the average production per worker, the wage share can also be described as total wages paid over the labor productivity. However, total wages paid over total value added will be used for describing the wage share.

\subsection{The model for examining changes in the wage share}

The model that will be used in this study is based on the wage bargaining model that is formed by Harrison (2002) for examining the impact of trade liberalization on the share of wages. In the model, Harrison (2002) shows the impact of trade liberalization by using a Nash bargaining framework and integrates effects of trade measures of globalization such as trade shares, exchange rates, capital flows on the bargaining power of labor and capital.

In the model, there are only two factors of production, labor and capital. The firm uses a vector of $\mathrm{v}$ outputs, $\mathrm{v}_{\mathrm{L}}$ showing the amount of labor and $\mathrm{v}_{\mathrm{K}}$ showing the amount of capital. The wage under perfect competition is $\mathrm{w}_{\mathrm{L} O}$ and the return of capital under perfect competition is $\mathrm{w}_{\mathrm{K} 0}$. The excess returns in the model is shown by the vector, $\mathrm{w}=\left(\mathrm{w}_{\mathrm{K}}, \mathrm{w}_{\mathrm{L}}\right)$. Thus, the utility functions for capital and labor are:

$U_{K}=\left(\mathrm{w}_{\mathrm{K}}-\mathrm{w}_{\mathrm{K} 0}\right) \mathrm{v}_{\mathrm{K}}$

$U_{L}=\left(\mathrm{w}_{\mathrm{L}}-\mathrm{w}_{\mathrm{L} 0}\right) \mathrm{v}_{\mathrm{L}}$

The revenue function is donated by $G(P, v)$ and the rents are given by $\left(G(R)-w_{0} R\right)$, where as $\mathrm{R}$ is the optimal choice of $\mathrm{v}$. For examining the bargaining between labor and capital, the labor share $\left(\lambda_{\mathrm{L}}\right)$ and the capital share $\left(\lambda_{\mathrm{K}}\right)$ is defined assuming that the sum of labor and capital shares are equal to 1 . Hence the outcome of Nash bargaining could be found from the following equation:

$\left[\lambda_{\mathrm{L}}\left(\mathrm{G}(\mathrm{R})-\mathrm{w}_{0} \mathrm{R}\right)-\mathrm{U}_{\mathrm{L} 0}\right] *\left[\left(1-\lambda_{\mathrm{L}}\right)\left(\left(\mathrm{G}(\mathrm{R})-\mathrm{w}_{0} \mathrm{R}\right)-\mathrm{U}_{\mathrm{K} 0}\right]\right.$

In this equation $\mathrm{U}_{\mathrm{L} 0}$ and $\mathrm{U}_{\mathrm{K} 0}$ are defined as the utilities that labor and capital will get, when the bargaining breaks down. The break down of the bargaining process is defined as either capital's or labor's option of leaving the country. As the capital or 
labor leave the country, they pay a fixed cost of $F_{K}$ or $F_{L}$. Thus, the utilities of leaving the country are defined as:

$$
\begin{aligned}
& U_{K 0}=\left(\mathrm{w}_{\mathrm{K}}^{*}-\mathrm{w}_{\mathrm{K} 0}\right) \mathrm{v}_{\mathrm{K}}-\mathrm{F}_{\mathrm{K}} \\
& U_{L 0}=\left(\mathrm{w}_{\mathrm{L}}^{*}-\mathrm{w}_{\mathrm{L} 0}\right) \mathrm{v}_{\mathrm{L}}-\mathrm{F}_{\mathrm{L}}
\end{aligned}
$$

In these equations $\mathrm{w}_{\mathrm{i}}{ }^{*}$ is defined as the gains of factors under perfect competition at home plus the premium $\left(\varphi_{i}\right)$ for reallocating abroad. Thus, the $\mathrm{w}_{\mathrm{i}}{ }^{*}$ is given by the following equation: $\mathrm{w}_{\mathrm{i}}{ }^{*}=\mathrm{w}_{\mathrm{i} 0}+\varphi_{\mathrm{i}}$ The fixed costs are assumed to be proportional to the revenues and defined as $\mathrm{F}_{\mathrm{i}}=\mathrm{f}_{\mathrm{i}} * \mathrm{G}(\mathrm{R})$. Hence, the utilities are rewritten as:

$$
\begin{aligned}
& U_{K 0}=\varphi_{\mathrm{K}} \mathrm{v}_{\mathrm{K}}-\mathrm{f}_{\mathrm{K}} \mathrm{G}(\mathrm{R}) \\
& U_{L 0}=\varphi_{\mathrm{L}} \mathrm{v}_{\mathrm{L}}-\mathrm{f}_{\mathrm{L}} \mathrm{G}(\mathrm{R})
\end{aligned}
$$

As a result, the following equation is maximized by $\lambda_{\mathrm{L}}$, according to the Nash bargaining:

$$
\left\{\lambda_{\mathrm{L}}\left[\mathrm{G}(\mathrm{R})-\mathrm{w}_{0} \mathrm{R}\right]-\varphi_{\mathrm{L}} \mathrm{v}_{\mathrm{L}}+\mathrm{f}_{\mathrm{L}} \mathrm{G}(\mathrm{R})\right\} \times\left\{\left(1-\lambda_{\mathrm{L}}\right)\left[\mathrm{G}(\mathrm{R})-\mathrm{w}_{0} \mathrm{R}\right]-\varphi_{\mathrm{K}} \mathrm{v}_{\mathrm{K}}+\mathrm{f}_{\mathrm{k}} \mathrm{G}(\mathrm{R})\right\}
$$

Finally, by solving the equation the following result is estimated for labor share $S_{L}$ :

$$
\begin{aligned}
& \mathrm{w}_{\mathrm{L}} \mathrm{v}_{\mathrm{L}} / \mathrm{G}(\mathrm{R})=\mathrm{S}_{\mathrm{L}} \\
& =1 / 2\left[\left(\mathrm{w}_{0 \mathrm{~L}} \mathrm{v}_{\mathrm{L}}-\mathrm{w}_{0 \mathrm{~K}} \mathrm{v}_{\mathrm{K}}\right) / \mathrm{G}(\mathrm{R})\right]+1 / 2+1 / 2\left(\varphi_{\mathrm{L}} \mathrm{v}_{\mathrm{L}} / \mathrm{G}(\mathrm{R})-\varphi_{\mathrm{K}} \mathrm{v}_{\mathrm{K}} / \mathrm{G}(\mathrm{R})\right)+\left(\mathrm{f}_{\mathrm{K}}-\mathrm{f}_{\mathrm{L}}\right) / 2
\end{aligned}
$$

The model shows that the wage share declines as the premium of capital for moving production abroad rises. The model also shows that as the fixed costs of capital for reallocating decline, the wage shares declines. Hence, the model finds a negative correlation between liberalization and the wage shares, through the former's effect on relative bargaining power of labor and capital. In the article, the model is transformed the final following model is estimated for the empirical analysis:

$$
\mathrm{S}_{\mathrm{Lt}}=\gamma_{0}+\gamma_{1} \ln \left(\mathrm{L}_{\mathrm{t}} / \mathrm{K}_{\mathrm{t}}\right)+1 / 2\left(\varphi_{\mathrm{L}} \mathrm{v}_{\mathrm{L}} / \mathrm{G}(\mathrm{R})-\varphi_{\mathrm{K}} \mathrm{v}_{\mathrm{K}} / \mathrm{G}(\mathrm{R})\right)+\left(\mathrm{f}_{\mathrm{K}}-\mathrm{f}_{\mathrm{L}}\right) / 2
$$

In this study, a model based on Harrison's model is formed for estimating the factors behind the determination of the wage shares. The factors that affect the wage shares 
in different sectors are estimated by using a panel regression including 22 subsectors of the manufacturing industry in the years between 1981-2001. Several variables are used for showing changes in the premium and the fixed costs of capital for reallocating abroad and of globalization. Also, some control variables are added to the empirical model. The empirical model that is used in this study can be shown as:

$$
\begin{aligned}
\mathrm{WS}_{\mathrm{it}} & =\mathrm{b}_{1} \ln (\mathrm{K} / \mathrm{L})_{\mathrm{it}}+\mathrm{b}_{2} \ln (\mathrm{EXP})_{\mathrm{it}}+\mathrm{b}_{3} \ln \left(\mathrm{EXP} \_1\right)_{\mathrm{it}}+\mathrm{b}_{4} \ln (\mathrm{IMP})_{\mathrm{it}}+\mathrm{b}_{5} \ln \left(\mathrm{IMP} \_1\right)_{\mathrm{it}} \\
& +\mathrm{b}_{6} \mathrm{SIZE}_{\mathrm{it}}+\mathrm{b}_{7} \mathrm{RER}_{\mathrm{t}}+\mathrm{b}_{8} \mathrm{ENF}_{\mathrm{t}}+\mathrm{b}_{9}\left(\mathrm{ENF}_{-} 1\right)_{\mathrm{t}}
\end{aligned}
$$

$\mathbf{i}=$ sectors manufacturing industry according to 2 digit ISIC rev. $3(15, \ldots, 36)$

$\mathbf{t}=$ year $(1981, \ldots, 2001)$

$\mathbf{W S}=$ wage share

$\mathbf{K} / \mathbf{L}=$ real capital input (million TL) / number of workers

$\mathbf{E X P}=$ export/value added

EXP_1 = one year lag of export/value added

IMP $=\mathrm{import} / \mathrm{value}$ added

IMP_1 = one year lag of import/value added

SIZE $=$ average number of workers working in a firm

$\mathbf{R E R}=$ real exchange rate(TL/currency according to foreign currency basket)

$\mathbf{E N F}=$ inflation

ENF_1 = one year lag of inflation

22 sectors that are chosen for the analysis are all sub-sectors of manufacturing industry (Appendix-A). Only sectors from the manufacturing industry are chosen, since detailed wage statistics are not available for services and agriculture. However, in the manufacturing industry mainly tradable sectors are produced, the changes in the trade flows firstly affected the wages in the manufacturing industry. The impact of change in trade flows on the wages in services sector is probably observed as an indirect effect of change in wages in industry. The wages in the services sector would not be expected to be affected by trade flows, since mostly nontradable goods are produced in the services sector. Therefore, the examination of wage shares in manufacturing industry is expected to show the main impact of trade flows on functional income distribution. 
A part of changes in the premium for reallocating abroad and in the fixed costs of reallocating abroad are captured by export/value added and import/value added variables. It is assumed that in the case of the reduction in the fixed reallocation costs and increase in the reallocating premium will result in increase on trade flows. Hence, the effects of these changes are shown by using variables related with trade flows. As the economy gets more open to the trade flows, the firms will have a better option of moving part of their production or their whole production to the countries where lower wages are paid. The threat of reallocation could lower the bargaining power of workers. Especially, in the export oriented sectors the firms are expected use this threat more severely for the aim of competing with the firms in the countries where lower wages are paid. Thus, the wage shares are expected to be affected negatively from the increases in exports.

For the imports, the wage shares could also be negatively affected from the imports of consumption goods and intermediate goods that are brought from the countries where lower wages are paid. However, the impact of import/value added variable is ambigious, since a part of imported goods might not be produced in Turkey. These goods either could be high technology products or products that are produced from specific minerals. In this case, the imports of these goods would not be expected to have the effect of lowering the wage shares by reducing the labor's bargaining power. In the model, the lags of EXP and IMP variables are also used for estimating the long run effects of the trade flows.

The real exchange rate(RER) is also used for estimating the changes in the fixed costs of reallocating abroad. It is assumed that the appreciation of the exchange rate reduces the relative fixed costs for reallocating abroad, and hence has a depressing effect on labor shares. Also, Onaran and Yentürk (2003) observe a clear trade off between wage costs and non-wage costs in the post 1980 period in Turkish economy. Firms reduce their real wage costs for protecting their mark-up rates, in the periods that their non-wage costs in their rise. The appreciation of the domestic currency could increase the non-wage costs of firms by raising the price of domestic goods used in the phase of production and thus, result in reduction in wage shares. 
In the capital intensive sectors, the workers could have higher wage shares, since more skilled workers usually work in the capital intensive sectors. Hence, the wage shares might be expected to rise as the sector gets more capital intensive. However, an adverse effect of capital/labor(K/L) ratio might also be seen, because of the observed trade off between wage and non-wage costs. Therefore, increase in the amount of capital usage could depress wage shares by increasing the non-wage costs.

As the average number of workers(SIZE) working in a firm rise, the institutional structure of the firms in the sector could change in a positive way. Also, in the bigger firms the workers have a better chance of unionization and become active in bargaining process. Thus, increase in the size of the firms could affect labor positively. The changes on the investments could also affect on the wage shares by raising the labor demand in the sector that investments are made.

The unexpected changes in the prices could result in decline in the real wages. Thus, changes in the inflation(ENF) could cause a decline in the wage shares. For estimating the longer run effects of the changes in inflation on the wage shares, a year lag of inflation is also used in the model.

The Figure-2.4 showing the wage shares in the manufacturing industry shows that the wage shares declined severely during the financial crises years. For estimating the effects of the financial crises that occurred in the years 1994 and 2001, a second model is also used containing a crisis(CRI) dummy for the years 1994 and 2001:

$$
\begin{aligned}
\mathrm{WS}_{\mathrm{it}} & =\mathrm{b}_{1} \ln (\mathrm{K} / \mathrm{L})_{\mathrm{it}}+\mathrm{b}_{2} \ln (\mathrm{EXP})_{\mathrm{it}}+\mathrm{b}_{3} \ln \left(\mathrm{EXP} \_1\right)_{\mathrm{it}}+\mathrm{b}_{4} \ln (\mathrm{IMP})_{\mathrm{it}}+\mathrm{b}_{5} \ln \left(\mathrm{IMP} \_1\right)_{\mathrm{it}} \\
& +\mathrm{b}_{6} \mathrm{SIZE}_{\mathrm{it}}+\mathrm{b}_{7}\left(\mathrm{ENF}_{-} 1\right)_{\mathrm{t}}+\mathrm{b}_{8} \mathrm{CRI}_{\mathrm{t}}
\end{aligned}
$$

$\mathrm{i}=$ sectors manufacturing industry according to 2 digit ISIC rev. $3(15, \ldots, 36)$

$\mathrm{t}=$ year $(1981, \ldots, 2001)$

In the model the variables that could be directly affected from crisis(CRI) dummy are eliminated for raising the significance of the crisis dummy. Inflation(ENF) and real exchange rate(RER) variables are not used in the model; however, inflation's one year lag is used since this variable is not directly related with the economic crisis. 
The two models estimated will be also used by separating the sectors into two groups: skilled and unskilled. The skilled and the unskilled groups both include 11 sectors, the categorization is given in the Appendix-A. The changes in the trade flows might have different effects on the wages in skilled and unskilled sectors. According to the theories based on the Stopler-Samuelson theorem, as a result the trade liberalization the developing countries specialize on unskilled sectors and the demand on the unskilled labor increase. Hence, relative impact of the trade flows is expected to be more positive for the wage shares in the unskilled sectors. However, the theories on the political economy literature claim that the unskilled labor will be relatively more negatively affected from the trade liberalization process (Rodrik, 1997; Onaran, 2007a; Milanovic and Squire, 2005). The dominant effect on the wage shares in skilled and unskilled sectors is estimated by the empirical analysis made for skilled and unskilled sector.

\subsection{The data used in the empirical analysis:}

The industry statistics that is used in this analysis is mainly based on the private manufacturing industry statistics taken from Turkstat. The manufacturing industry statistics are formed by using Turkstat's Annual Manufacturing Industry Questionnaires. The Annual Manufacturing Industry Questionnaires are made annually in the private and public establishment with 10 or more people engaged. The estimation of Annual Manufacturing Industry Questionnaires time series ended in the year 2001, due to a revision in the scope of the survey. Therefore, only the data for the years 1980-2001 are used in this study. The number of establishments that questionnaires are covered change between 8707-11311. In this study, the statistics only for the private manufacturing industry are used. The reason for that is that the wage determination in the public sector could have different dynamics and could be affected from political effects that are not directly related with the economic progress.

The data taken from Turkstat divides manufacturing industry into the groups according to ISIC rev.2-digit classification. For the analysis, the data is transformed into ISIC 2-digit classification for achieving consistency between industry and foreign trade statistics. ISIC rev.3 2-digit classification divides the manufacturing industry into 22 sectors(15-36) according to the products produced in each sector. 
Value added, total wages paid, number of workers per firm, input and investment data are gathered from the Annual Manufacturing Industry Statistics. The real capital input data that is used in capital/labor ratio, is calculated by using ICOC's total commodity price index $(1968=100)$ and 1981 is chosen as the base year of deflator.

The foreign trade statistics are gathered from Turkstat's foreign trade database, which is available at Turkstat's website: www.turkstat.gov.tr. Turkstat obtains the export and import statistics for the sectors classified according to ISIC rev.3 2-digit classification. ICOC's total commodity price index $(1968=100)$ is also used for the inflation rate statistics. The Inflation rate statistics are gathered from the Central Bank of the Republic of Turkey(CBRT)'s website: evds.tcmb.gov.tr. The real exchange rate statistics are also taken from CBRT's website. The real exchange rates are calculated by CBRT according to the producer price index and the currency calculated from the currencies of seventeen countries.

\subsection{The empirical analysis:}

In the study both fixed effects and random effects estimators are used for showing the reasons behind the changes in the wage shares. Autocorrelation problems are found for all of the fixed effects regressions; hence, fixed effects regressions with first-order autoregressive (AR1) disturbances are used instead of the classical fixed effects model (Appendix-B). In the random effects models, both heteroskedasticity and autocorrelation problems are found. For fixing these problems, Prais-Winsten regression is used instead of the classical random effects model. Prais-Winsten regression adjusts the standard errors for panel heteroskedasticity and contemporaneous correlation and transforms the model to account for a $\operatorname{AR}(1)$ process.

According to the Hausman tests made for all of the models that are used in this study, the assumptions of GLS estimators fail. Therefore, the fixed effects regressions could be considered as more reliable compared to the Prais-Winsten regressions (Appendix-B). The regressions with a crisis dummy clearly shows the impact of 1994 and 2001 financial crises on the wage shares. However, it must be noted that the regressions with ENF and RER variables are more complex and the coefficient of determination $\left(\mathrm{R}^{2}\right)$ are higher compared to the models with a crisis dummy. 
Therefore, in this study the regressions without a crisis dummy could be considered as more reliable.

According to the models that contain all of the sectors (Table 5.1), the lag of export/value added ratio(EXP_1) and the lag of import/value added ratio(IMP_1) are negatively correlated with the wage share. As the sector gets more open, in the long term the rising global competition is found to have a depressing effect on wages by lowering the bargaining power of labor. The estimations show that $1 \%$ increase in a year lag of the export/value added ratio(EXP_1) results in a 0.0082 to 0.0141 point decline and a year lag of the import/value added ratio(IMP_1) results in a 0.0111 to 0.0137 point in the wage share. Considering the existence of big changes in the export/value added(EXP_1) and import/value added ratio(IMP_1) ratios in many sectors that are affected from the trade liberalization period(Appendix-C), the total effect on wage share could add up to be substantial.

In the short term, the import/value added ratio(IMP) is found to have a statistically significant positive impact on the wage shares, which could be considered as an unexpected result. Table 5.3 shows that the positive impact of the import/value added ratio(IMP) is much higher in the skilled sectors. This could mean that the positive impact of import/value added ratio(IMP) on the wage share is mostly due to the imports in the skilled sectors. The imports of high-technology goods that are not produced in Turkey could improve the skilled sectors and hence create an extra labor demand in them.

The increases in the capital inputs/labor ratio(K/L) have a significant negative effect on the wage shares. The effect of capital inputs/labor ratio(K/L) could be explained by firms' trade-off between wage and non-wage costs (Onaran and Yentürk, 2003). In the Turkish economy, the firms are willing to depress the real wages in the periods where non-labor costs rise. Probably due to the same reason the real appreciation of TL is also found to be negatively correlated with the wage shares. As the TL appreciates the non-labor costs of firms increase, which puts a pressure on the wage shares. Also, the appreciation of TL makes outsourcing or offshoring more profitable. The raising threat of moving production to a foreign country could also negatively effect the wage shares by weaking the bargaining power of labor. 
The inflation has a statistically significant negative effect on the wage shares. Both inflation and a year lag of inflation are negatively correlated with the wage share. This shows that the price elasticity of nominal wages is low. Also, the rise in the average size of the firms(SIZE) in a sector positively affects the wage shares. The reason for that is that firms with a larger scale have a better institutional structure and workers have a better chance of unionizing in the bigger scale firms.

Table-5.1: The impact of trade flows on wage shares (1981-2001)

\begin{tabular}{|c|c|c|c|c|}
\hline \multirow[t]{2}{*}{ Wage Share(WS) } & \multicolumn{2}{|c|}{$\begin{array}{c}\text { Fixed effects with } \mathrm{AR}(1) \\
\text { disturbances }\end{array}$} & \multicolumn{2}{|c|}{ Prais-Winsten regression } \\
\hline & (1) & (2) & (3) & (4) \\
\hline $\operatorname{Ln}(\mathrm{K} / \mathrm{L})$ & $\begin{array}{l}-5.93^{*} \\
(0.69)\end{array}$ & $\begin{array}{l}-4.74^{*} \\
(0.79)\end{array}$ & $\begin{array}{l}-6.00^{*} \\
(0.58)\end{array}$ & $\begin{array}{l}-5.91^{*} \\
(0.69)\end{array}$ \\
\hline $\operatorname{Ln}(\mathrm{EXP})$ & $\begin{array}{c}0.49 \\
(0.35)\end{array}$ & $\begin{array}{c}0.57 \\
(0.39)\end{array}$ & $\begin{array}{l}0.79^{* * *} \\
(0.43)\end{array}$ & $\begin{array}{c}0.68 \\
(0.44)\end{array}$ \\
\hline Ln(EXP_1) & $\begin{array}{l}-1.41^{*} \\
(0.36)\end{array}$ & $\begin{array}{l}-1.10^{*} \\
(0.38)\end{array}$ & $\begin{array}{l}-0.82^{* *} \\
(0.38)\end{array}$ & $\begin{array}{l}-0.94^{* *} \\
(0.39)\end{array}$ \\
\hline $\operatorname{Ln}(\mathrm{IMP})$ & $\begin{array}{l}2.33^{*} \\
(0.46)\end{array}$ & $\begin{array}{l}2.73^{*} \\
(0.50)\end{array}$ & $\begin{array}{l}2.13^{*} \\
(0.54)\end{array}$ & $\begin{array}{l}2.16^{*} \\
(0.53)\end{array}$ \\
\hline Ln(IMP_1) & $\begin{array}{l}-1.18^{*} \\
(0.43)\end{array}$ & $\begin{array}{l}-1.11^{* *} \\
(0.46)\end{array}$ & $\begin{array}{l}-1.26^{* *} \\
(0.52)\end{array}$ & $\begin{array}{l}-1.37^{*} \\
(0.51)\end{array}$ \\
\hline $\begin{array}{l}\text { Real Exchange } \\
\text { Rate(RER) }\end{array}$ & $\begin{array}{l}0.09^{*} \\
(0.01)\end{array}$ & - & $\begin{array}{l}0.10^{*} \\
(0.02)\end{array}$ & - \\
\hline Inflation (ENF) & $\begin{array}{l}-0.05^{*} \\
(0.01)\end{array}$ & - & $\begin{array}{l}-0.05^{*} \\
(0.01)\end{array}$ & - \\
\hline $\begin{array}{c}\text { A year lag of } \\
\text { inflation(ENF_1) }\end{array}$ & $\begin{array}{l}-0.01 \\
(0.01)\end{array}$ & $\begin{array}{l}-0.03^{*} \\
(0.01)\end{array}$ & $\begin{array}{l}-0.01 \\
(0.01)\end{array}$ & $\begin{array}{l}-0.01 \\
(0.01)\end{array}$ \\
\hline $\begin{array}{l}\text { No. of workers per } \\
\quad \text { firm (SIZE) }\end{array}$ & $\begin{array}{l}0.04^{*} \\
(0.01)\end{array}$ & $\begin{array}{l}0.05^{*} \\
(0.01)\end{array}$ & $\begin{array}{c}0.01 \\
(0.01)\end{array}$ & $\begin{array}{c}0.01 \\
(0.01)\end{array}$ \\
\hline Crisis(CRI) & - & $\begin{array}{l}-3.01^{*} \\
(0.61)\end{array}$ & - & $\begin{array}{l}-2.89^{*} \\
(0.65)\end{array}$ \\
\hline Constant & $\begin{array}{l}58.20^{*} \\
(3.23)\end{array}$ & $\begin{array}{l}53.51^{*} \\
(3.25)\end{array}$ & $\begin{array}{l}59.20 \\
(4.77)\end{array}$ & $\begin{array}{l}69.32^{*} \\
(5.22)\end{array}$ \\
\hline $\mathrm{R}^{2}$ & 0.40 & 0.26 & 0.57 & 0.49 \\
\hline
\end{tabular}

Note: $* * *$ denotes statistical significance at the $10 \%$ level; **denotes statistical significance at the $5 \%$ level; and $*$ denotes statistical significance at the $1 \%$ level. 
Turkey experienced two economic crises on the years 1994 and 2001. The economic crises are mainly caused by the capital outflows. It can be said that, the rising frequency of economic crises are directly related with the financial liberalization and the economic crises caused by capital outflows have a significant devastating impact on the wage shares (Cornia, 2006; Pollin, 2002). The economic crisis also has a significant negative impact on the wage share in Turkey. An economic crisis resulted with decline around $3 \%$ in the wage shares.

In the unskilled sectors, openness have different effects on the wage shares in the short and long run (Table-5.2). In the short run, the rise in the export/value added (EXP) and import/value added(IMP) ratios have a positive impact on the wage shares that is consistent with the Stolper-Samuelson theorem. An increase in the openness in the unskilled sectors increases demand for unskilled labor and affects wage shares positively. However, the positive impact of the export/value added(EXP) and import/value added(IMP) are reduced in the longer run. The increasing global competition and capital's rising threat of reallocating reduces labor's bargaining and hence the wage shares. Hence, a year lag of the export/value added(EXP_1) and import/value added(IMP_1) ratios have a negative impact on the wage share. Reallocating production to a country where lower wages are paid is easier in the unskilled sectors. Thus, the negative impact of a year lag of the export/value added (EXP_1) is higher in the unskilled sectors.

The changes in the capital/labor(K/L) ratio have a more significant impact on labor in the unskilled sectors. This result shows that the trade-off that firms make between labor and non-labor costs is more significantly seen in the unskilled sectors. The negative impact of the inflation on the wage shares is also higher for the unskilled sectors. The price elasticity of nominal wages are even lower in the unskilled sectors.

As expected, the negative impacts of the economic crises on the wage shares are slightly higher for the unskilled sectors. The volatilities affect wages unskilled sectors higher and the unskilled labor could not reduce the negative impact of the volatilities easily (Rodrik, 1998). Thus, compared to the skilled sectors, the wage shares in the unskilled sectors are more negatively affected from the economic crises in 1994 and 2001. 
Table-5.2: The impact of trade flows on wage shares in unskilled sectors(19812001)

\begin{tabular}{|c|c|c|c|c|}
\hline \multirow{2}{*}{ Wage Share(WS) } & \multicolumn{2}{|c|}{$\begin{array}{c}\text { Fixed effects with } \mathrm{AR}(1) \\
\text { disturbances }\end{array}$} & \multicolumn{2}{|c|}{ Prais-Winsten regression } \\
\hline & (1) & (2) & (3) & (4) \\
\hline $\operatorname{Ln}(\mathrm{K} / \mathrm{L})$ & $\begin{array}{l}-5.46^{*} \\
(0.89)\end{array}$ & $\begin{array}{l}-3.65^{*} \\
(1.22)\end{array}$ & $\begin{array}{l}-5.00^{*} \\
(0.66)\end{array}$ & $\begin{array}{l}-5.11^{*} \\
(0.87)\end{array}$ \\
\hline $\operatorname{Ln}(\mathrm{EXP})$ & $\begin{array}{l}0.91^{* *} \\
(0.42)\end{array}$ & $\begin{array}{l}0.83^{* * *} \\
(0.50)\end{array}$ & $\begin{array}{l}1.51^{*} \\
(0.53)\end{array}$ & $\begin{array}{l}1.21^{* *} \\
(0.56)\end{array}$ \\
\hline Ln(EXP_1) & $\begin{array}{l}-1.32^{*} \\
(0.44)\end{array}$ & $\begin{array}{l}-1.15^{* *} \\
(0.49)\end{array}$ & $\begin{array}{l}-1.17^{*} \\
(0.45)\end{array}$ & $\begin{array}{l}-1.34^{*} \\
(0.47)\end{array}$ \\
\hline $\operatorname{Ln}(\mathrm{IMP})$ & $\begin{array}{l}1.13^{* *} \\
(0.44)\end{array}$ & $\begin{array}{l}1.51^{*} \\
(0.49)\end{array}$ & $\begin{array}{l}0.83^{* * *} \\
(0.47)\end{array}$ & $\begin{array}{l}1.05^{* *} \\
(0.48)\end{array}$ \\
\hline Ln(IMP_1) & $\begin{array}{l}-0.68^{* * * *} \\
(0.41)\end{array}$ & $\begin{array}{l}-0.93^{* *} \\
(0.46)\end{array}$ & $\begin{array}{l}-0.45 \\
(0.46)\end{array}$ & $\begin{array}{l}-0.93^{* *} \\
(0.48)\end{array}$ \\
\hline $\begin{array}{l}\text { Real Exchange } \\
\text { Rate(RER) }\end{array}$ & $\begin{array}{l}0.09^{*} \\
(0.01)\end{array}$ & - & $\begin{array}{l}0.09^{*} \\
(0.02)\end{array}$ & - \\
\hline Inflation (ENF) & $\begin{array}{l}-0.06^{*} \\
(0.01)\end{array}$ & - & $\begin{array}{l}-0.06^{*} \\
(0.01)\end{array}$ & - \\
\hline $\begin{array}{c}\text { A year lag of } \\
\text { inflation(ENF_1) }\end{array}$ & $\begin{array}{l}-0.01 \\
(0.01)\end{array}$ & $\begin{array}{l}-0.03^{*} \\
(0.01)\end{array}$ & $\begin{array}{c}0.00 \\
(0.01)\end{array}$ & $\begin{array}{l}-0.01 \\
(0.01)\end{array}$ \\
\hline $\begin{array}{l}\text { No. of workers per } \\
\text { firm (SIZE) }\end{array}$ & $\begin{array}{c}0.01 \\
(0.01)\end{array}$ & $\begin{array}{c}0.00 \\
(0.01)\end{array}$ & $\begin{array}{c}-0.01^{* * *} \\
(0.01)\end{array}$ & $\begin{array}{l}-0.02^{* * *} \\
(0.01)\end{array}$ \\
\hline Crisis(CRI) & - & $\begin{array}{l}-3.51^{*} \\
(0.65)\end{array}$ & - & $\begin{array}{l}-3.41^{*} \\
(0.71)\end{array}$ \\
\hline Constant & $\begin{array}{l}59.08^{*} \\
(4.60)\end{array}$ & $\begin{array}{l}51.46^{*} \\
(4.60)\end{array}$ & $\begin{array}{l}53.76^{*} \\
(4.94)\end{array}$ & $\begin{array}{l}65.93^{*} \\
(6.36)\end{array}$ \\
\hline $\mathrm{R}^{2}$ & 0.54 & 0.30 & 0.70 & 0.61 \\
\hline
\end{tabular}

Note: $* * *$ denotes statistical significance at the $10 \%$ level; **denotes statistical significance at the $5 \%$ level; and $*$ denotes statistical significance at the $1 \%$ level.

In the skilled sectors, according to the FE regression, the export/value added ratios(EXP) are negatively correlated with the wage shares in the long run that is consistent both with the assumptions of the political economy literature (Table-5.3). According to both FE and Prais-Winsten regressions, the import/value added ratio is highly negatively correlated with the wage shares in the skilled sectors. The imports of high technology intermediate goods likewise computer chips could have increased the production in the sectors where imports are made. Hence, these high technology 
imports could increase the labor demand in the skilled sectors. Therefore, it can be said that the trade liberalization in the high technology products that are not produced in Turkey could effect the income distribution in Turkey positively.

Table-5.3: The impact of trade flows on wage shares in skilled sectors(19812001)

\begin{tabular}{|c|c|c|c|c|}
\hline \multirow{2}{*}{ Wage Share(WS) } & \multicolumn{2}{|c|}{$\begin{array}{c}\text { Fixed effects with AR(1) } \\
\text { disturbances }\end{array}$} & \multicolumn{2}{|c|}{ Prais-Winsten regression } \\
\hline & (1) & (2) & (3) & (4) \\
\hline $\operatorname{Ln}(\mathrm{K} / \mathrm{L})$ & $\begin{array}{l}-6.72^{*} \\
(0.97)\end{array}$ & $\begin{array}{l}-5.35^{*} \\
(1.09)\end{array}$ & $\begin{array}{l}-6.72^{*} \\
(0.74)\end{array}$ & $\begin{array}{l}-6.45^{*} \\
(0.85)\end{array}$ \\
\hline $\operatorname{Ln}(\mathrm{EXP})$ & $\begin{array}{c}0.42 \\
(0.54)\end{array}$ & $\begin{array}{c}0.48 \\
(0.58)\end{array}$ & $\begin{array}{l}-0.07 \\
(0.61)\end{array}$ & $\begin{array}{l}-0.04 \\
(0.64)\end{array}$ \\
\hline Ln(EXP_1) & $\begin{array}{l}-1.15^{* *} \\
(0.56)\end{array}$ & $\begin{array}{l}-0.97^{* * * *} \\
(0.58)\end{array}$ & $\begin{array}{l}-0.74 \\
(0.57)\end{array}$ & $\begin{array}{l}-0.96 \\
(0.59)\end{array}$ \\
\hline $\operatorname{Ln}(\mathrm{IMP})$ & $\begin{array}{l}4.03^{*} \\
(0.89)\end{array}$ & $\begin{array}{l}5.04^{*} \\
(0.94)\end{array}$ & $\begin{array}{l}3.52^{*} \\
(0.89)\end{array}$ & $\begin{array}{l}3.61^{*} \\
(0.89)\end{array}$ \\
\hline Ln(IMP_1) & $\begin{array}{l}-1.84^{* *} \\
(0.83)\end{array}$ & $\begin{array}{l}-1.03 \\
(0.90)\end{array}$ & $\begin{array}{l}-2.15^{* *} \\
(0.88)\end{array}$ & $\begin{array}{l}-2.00^{* * *} \\
(0.89)\end{array}$ \\
\hline $\begin{array}{l}\text { Real Exchange } \\
\text { Rate(RER) }\end{array}$ & $\begin{array}{l}0.11^{*} \\
(0.03)\end{array}$ & - & $\begin{array}{l}0.12^{*} \\
(0.03)\end{array}$ & - \\
\hline Inflation (ENF) & $\begin{array}{l}-0.04^{* *} \\
(0.02)\end{array}$ & - & $\begin{array}{c}-0.03^{* * * *} \\
(0.02)\end{array}$ & - \\
\hline $\begin{array}{c}\text { A year lag of } \\
\text { inflation(ENF_1) }\end{array}$ & $\begin{array}{l}-0.02 \\
(0.02)\end{array}$ & $\begin{array}{l}-0.04^{* *} \\
(0.02)\end{array}$ & $\begin{array}{l}-0.02 \\
(0.01)\end{array}$ & $\begin{array}{l}-0.02 \\
(0.02)\end{array}$ \\
\hline $\begin{array}{l}\text { No. of workers per } \\
\text { firm (SIZE) }\end{array}$ & $\begin{array}{l}0.12^{*} \\
(0.02)\end{array}$ & $\begin{array}{l}0.13^{*} \\
(0.02)\end{array}$ & $\begin{array}{l}0.07^{*} \\
(0.01)\end{array}$ & $\begin{array}{l}0.08^{*} \\
(0.01)\end{array}$ \\
\hline Crisis(CRI) & - & $\begin{array}{l}-2.74^{* * * *} \\
(0.98)\end{array}$ & - & $\begin{array}{l}-2.42^{* *} \\
(1.01)\end{array}$ \\
\hline Constant & $\begin{array}{l}49.23^{*} \\
(5.44)\end{array}$ & $\begin{array}{l}37.87^{*} \\
(5.16)\end{array}$ & $\begin{array}{l}57.76^{*} \\
(6.58)\end{array}$ & $\begin{array}{l}66.86^{*} \\
(7.30)\end{array}$ \\
\hline $\mathrm{R}^{2}$ & 0.44 & 0.32 & 0.58 & 0.50 \\
\hline
\end{tabular}

Note: $* * *$ denotes statistical significance at the $10 \%$ level; $* *$ denotes statistical significance at the $5 \%$ level; and $*$ denotes statistical significance at the $1 \%$ level.

The capital/labor $(\mathrm{K} / \mathrm{L})$ ratio has a higher negative impact on the wage shares in the skilled sectors. The pressure on wages is higher in the skilled sectors in the periods that non-wage costs increase. The impact of inflation (ENF) is also statistically 
significant for the skilled sectors. However, the negative impact of inflation (ENF) is lower in the skilled sectors compared to the unskilled sectors. The price elasticity of wages are higher in the skilled sectors; thus, the wage shares are not significantly affected from the changes in the prices. The negative impact of economic crises is also lower impact on the wage shares. These results show that both economic crises and inflation could increase the wage gap between the workers in the skilled and unskilled sectors.

In this section, the impact of trade flows on the wage shares in industry is analyzed by using panel data regressions. The estimations show that in the long run the export/value added and import/value added ratios are negatively correlated with the wage shares, and hence a negative distributional impact. For the unskilled sectors, a positive impact of openness on the wage shares is found for the short term due to the rise in the labor demand in the sectors that exports are made. However, this positive impact is diminished after a year with the effect of wage depressing impact of global competition. In the skilled sectors, the negative effect of the exports and imports on the wage shares are found for the long term. However, a positive impact of import/value added ratio is also found probably due to the high technology imports that are not produced in Turkey. According to the estimations, the economic crises occurred in the years 1994 and 2001 had a statistically significant negative impact on the wage shares. The negative impact of the economic crises is more severe for the unskilled sectors as expected. 


\section{CONCLUSION}

In this study, the impact of globalization on the individual and functional income distribution in Turkey is shown by examining the income distribution statistics and building a theoretical and empirical framework. The changes in the inequality in the post 1980 period is analyzed by using different measures of inequality that comes from different sources. The reliability of different income distribution statistics is also examined by making comparisons between statistics that comes from different sources. The study mainly focuses on the impact of trade flows on the inequality. However, in the empirical analysis the impact of financial crises that is caused by capital outflows is also shown.

As the Shorrocks decomposition analysis made in this study shows the entrepreneurial income is the main source of the inequality in Turkey. Thus, the share of income between entrepreneurs and labor has a more crucial effect on the individual inequality compared to the inequality within wages. Thus, the impact of globalization on the changes in the wage shares and the functional income distribution is deeply analyzed in this study.

The literature on the impact of trade liberalization on wages contains many different perspectives. The Stolper-Samuelson theorem is widely discussed in the literature and could be considered as the starting point of the discussions on the relationship between trade and distribution. The Stolper-Samuelson theorem claims that the trade liberalization will increase the demand on the labor intensive developing countries and hence the labor will be affected positively from the rising trade flows. Similarly, the extensions of the Stolper-Samuelson theorem claim that the trade liberalization will be in favor of unskilled labor in the developing countries; since the unskilled labor intensive developing countries will specialize in unskilled sectors and the demand and hence the wages of unskilled labor will rise. 
The Stolper-Samuelson theorem relies on simple assumptions and is criticized by many economists. The theories in political economy literature usually focus on the negative impact of raising labor flexibility. As a result of trade liberalization, the capital's options of reallocating in another country are increased. The rising global competitiveness and increasing options of reallocation forced capital to look for a country with the cheaper labor and facilities for making production. Thus, the labor flexibility increased and the bargaining power of the labor declined severely. Therefore, according to the theories in the political economy literature; the labor shares are negatively affected from the trade liberalization. Contrary to the assumptions that come from Stolper-Samuelson theorem the theories in the political economy literature assumes that the unskilled labor will be affected from trade liberalization more severely, since moving the production in the unskilled sectors is easier.

The classification of skilled and unskilled is also criticized in many articles, since many workers that are classified as unskilled in developed countries could be classified as skilled in the developing countries. Also the classification of developed and developing is also critized for being simple, since significantly cheper labor is avaliable in the low-income developing countries like China, compared to the medium-income developing countries like Turkey. It is also claimed that the globalization could increase the demand for the more skilled labor even in the unskilled sectors; since the rising competition in the period of globalization could force many sectors to use intensive technology.

The empirical works examining the impact of globalization on wages mainly shows that the trade flows has a negative effect on the functional income distribution. The negative impact of trade flows on the functional income distribution is also shown in many empirical studies made for Turkey. Thus, the results found in the empirical studies are inconsistent with the Stolper-Samuelson theorem.

The panel data analysis made in study also examines the correlation between the wage shares in the manufacturing industry and the trade flows for the years 19812001. The results of the analysis shows that the trade flows has a negative impact on the wage shares in the long run. This result is consistent with the theories of the political economy literature. According to the analysis made for all sectors a year lag 
of export/value added and import/value added ratios are negatively correlated with the wage shares. Thus, in the longer run the wage shares are affected from the rising global competition in the sectors that openness is observed. In the short run, the import/value added ratio has a statistically very significant positive effect on the wage share probably due to the imports made in the skilled sectors.

For the unskilled sectors, openness affect the wage shares positively in the short term. The rising openness impose a rising demand for the labor in unskilled sectors. However, the estimations also show that the positive impact of rise in exports and imports is not stable. A year lag of export/value added and import/value added ratios have a significant negative impact on the wage shares, which shows the positive impact of trade flows is reduced on the longer-term. This result is found probably due to the longer-term effect of rising export competition and labor flexibility.

For the skilled sectors, the export/value added ratio has a negative impact on wage shares in the longer term. The interesting result of the regression made for the skilled sectors is that, the import/value added ratio has a high positive impact on the wage shares in the skilled sectors. This result could be found due to the imports of high technology intermediate goods that are not produced in Turkey. The imports of high technology intermediate goods could be associated with the improvement in many skilled sectors and the improvement in these skilled sectors could increase the demand for the skilled labor.

The impact of economic crises that is caued by capital outflows is also examined in the panel data analysis. The results show that 1994 and 2001 crises have a negative significant effect on the wage shares. As expected, the negative effect of economic crises are higher for the unskilled labor. The results show that the economic crises not only results in decline in the wage share, but also results in increase in the wage inequality.

In this study, the income distribution statistics that comes from the Household Income Distribution data are also examined. According to the Household Income Distribution statistics, the Gini coefficient estimated declined from 0.44 to 0.38 between years 2002-2005. This value is far lower than the Gini coefficient of the 
year 1994, which is a year that 1994 economic crisis is experienced. The Gini coefficient in Turkey was calculated as 0.49 in the year 1994.

The high income inequality in the 1994 is due to the impact of the economic crises. The Shorrocks decomposition analyses shows that the high amount securities income that is caused by the economic crisis has a crucial effect on the high inequaity estimated. Thus, a comparison made between 1994 and the other years could not be considered as reliable.

However, the Gini coefficient is also declining between years 2002-2005 in which high amounts of increase in the trade flows is observed. The decline on the Gini coefficient might be due to the reduced impact of the 2001 economic crisis. According to the household income distribution statistics, the share of the securities income declined and the wage share rised after 2002 as the negative impact of the economic crisis is recovered. The rise in the wage share of the workers in the nontradable sectors could have especially positive impact on the inequality, since the workers in the nontradable sectors are not affected from increasing trade flows directly. Secondly, the reliability of the household income distribution statistics is doubtful. There are inconsistencies observed between the national accounts and household income distribution statistics. The wage shares are not in fact changing significantly between 2002-2005 according to the calculations made by using national accounts data.

The calculations that comes from the income distribution data shows that the wage shares in the industry, where tradable goods are produced declined between 20022005. Thus, the wage shares declined in the sectors that is affected from the trade flows. An increase in the wage share in services is observed and hence the wage share in the GDP did not change significantly.

Thus, the analysis made for the income distribution between the years 2002-2005 show that; although the Gini coefficient declined in these years that trade flows increased, the trade flows did not have an effect on the decline in the Gini coefficient. The decline in the Gini coefficient could be explained with the data problems and the factors that are not directly related with the trade flows.Also a 
decline in the wage share in industry is estimated between 2002-2005. Thus, it can be said that the decline in the Gini coefficient despite to rising trade flows. 


\section{REFERENCES}

Acemoğlu, D., 2003. Patterns Of Skill Premia, Review of Economic Studies, v70(2,Apr), 231-251

Arbache, J., Green, F. and A. Dickerson, 2004. Trade liberalization and wages in developing countries, Economic Journal, v.114, pp. F73-F96

Block, W., J. Dauterive and J. Levendis, 2007. Globalization and The Concept of Subsistance Wages., Journal of Income Distribution, Thistle Printing Limited, vol. 16(1), pages 73-87

Bohle, D. and B. Greskovits, 2005. Capital, labor, and the prospects of the European social model in the east, Central and Eastern Europe Working Papers, No. 58.

Boratav, K., E. Yeldan and A. Köse, 2000. Globalization, Distribution And Social Policy: Turkey: 1980-1998, CEPA and The New School for Social Research,Working Paper Series, No 20. New York, February.

Boratav, K. ,2003. Türkiye İktisat Tarihi: 1908-2002, İmge Yayınevi, Ankara.

Breuss, F. ,2007. Globalization, EU Enlargement and Income Distribution, FIW, Working Paper Series, No 008.

Bulutay, T., 2005. Türkiye Ekonomisinde Büyüme ve Bölüşüm Sorunları., İktisat İşletme ve Finans, v. 20, iss. 230, pp. 5-55

Bulutay, T., Timur,S. and Ersel,H.,1971. Türkiye'de Gelir Dağılımı, Ankara:SBF. SPO (1976), Gelir Dağılımı 1973, Ankara

Celasun, M., 1986. Income Distribution and Domestic Terms of Trade in Turkey, 1978-1983, METU studies in development ,13,issue 12.

Chotikapanich, D., D.S.P. Rao, W. E. Griffiths and V. Valencia, 2007. Global Inequality Recent Evidence and Trends., UNU-WIDER Research Paper No. 2007/01

Cornia, G., 2006. Potential and Limitations of Pro-Poor Macroeconomics: An Overview, Potential and Limitations of Pro-Poor Macroeconomics: An Overview, Ed. Cornia G., Palgrave-McMillan 
Cowell, F.A., 1995. Measuring Inequality, (Second Ed.), Prentice Hall, New York

Çavuşoğlu, T., and Y. Hamurdan, 1966. Gelir Dağı̆lımı Araştırması 1963, SPO, Ankara.

Davis, D. R. and P. Mishra, 2007. Stolper-Samuelson is Dead: And Other Crimes of Both Theory and Data, Globalization and Poverty, Ed. Harrison A. Chicago: U. of Chicago Pr..

Feenstra R.C. and A. Hanson, 1997. Foreign direct investment and relative wages: evidence from Mexico's mequiladoras, Journal of International Economics, vol.42, pp. 371- 394.

Freeman, R., 1995. Are Your Wages Set in Beijing?, The Journal of Economics Perspectives, Vol. 9, No. 3., pp. 15-32

Goldberg, P. K. and N. Pavcnik, 2007. Distributional Effects of Globalization in Developing Countries., NBER Workıng Paper Series Working Paper 12885 .

Harrison, A.E., 2002. Has globalization eroded labor's share? Some cross-country evidence, Mimeo, UC Berkeley.

IMF, 2007a. Globalization and Inequality, World Economic Outlook October 2007, Ch 4

IMF, 2007b. The Globalization of Labor, World Economic Outlook April 2007, Ch 5

Ilkkaracan, İ. and R. Selim, 2003. The Role of Unemployment in Wage Determination: Further Evidence on the Wage Curve in Turkey, Applied Economics, V.35, i.14, pp. 1589-99.

İlkkaracan, İ., 2004. Ücretlerin Belirlenme Süreçleri, Türkiye'de İşgücü Piyasası'nın Kurumsal Yapısı ve İssizlik, TÜSIAD, Istanbul

Kaplinsky, R., 2001. Is Globalization All it is Cracked Up to Be? Review of International Political Economy, Vol. 8, No. 1, Spring, pp. 45-65.

Kepenek, Y. and Yentürk, N., 1999 Türkiye Ekonomisi, Remzi Kitabevi, Istanbul.

Krugman, P., 2008. Trade and Wages, Reconsidered., Unpublished working paper, www.princeton.edu/ pkrugman/pk-bpea-draft.pdf

Landesmann M., H. Vidovic and T. Ward., 2004. Economic Restructuring and Labour Market Developments in the New EU Member States, The Vienna Institute for International Economic Studies (wiiw), Research Report no 313, December 2004 
Lee, E. and M. Vivarelli, 2006. The Social Impact of Globalization in the Developing Countries; International Labour Review, Vol. 145, No. 3

Metin-Özcan K., Voyvoda E. and E. Yeldan, 2000. 1980 Sonrası Türk İmalat Sanayiinin Gelişme Dinamikleri Üzerine Gözlemler, İşletme Finans, 15

Milanovic, B., 2005. Can We Discern the Effect of Globalization on Income Distribution? Evidence from Household Surveys., World Bank Economic Review, Oxford University Press, vol. 19(1), pages 21-44

Milanovic, B. and L. Squire, 2005. Does Tariff Liberalization Increase Wage Inequality? Some Empirical Evidence, NBER Working Papers 11046, National Bureau of Economic Research, Inc.

Onaran, Ö., 2002. Measuring wage flexibility: the case of Turkey before and after structural adjustment, Applied Economics, 34, 767-781

Onaran, Ö. and N. Yentürk, 2003. The Mark-up Rates in Turkish Private Manufacturing Industry during Trade Liberalization, Journal of Income Distribution, Vol. 11, Issue 3-4.

Onaran, Ö., 2007a. The effects of globalization on income distribution: A Literature Review and Implications for Europe and Austria., Kammer für Arbeiter und Angestellte für Wien, Abteilung Wirtschaftswissenschaft und Statistik, Materialien zu Wirtschaft und Gesellschaft ; 100

Onaran, Ö., 2007b. Wage Share, Globalization, and Crisis: The Case of the Manufacturing Industry in Korea, Mexico, and Turkey., Political Economy Research Institute Working Paper Series Number 132.

Pollin, R., 2002. Globalization and the Transition to Egaliterean Development, Political Economy Research Institute Working Papers, 42.

Ravallion, M., 2003. Measuring Aggregate Welfare in Developing Countries: How Well Do National Accounts and Surveys Agree?, The Review of Economics and Statistics. Vol. 85, No. 3, Pages 645-652

Rodrik, D.,1997. Has Globalization Gone Too Far?, Institute for International Economics, Washington D.C.

Sala-i-Martin, X., 2001. The disturbing 'rise' of global income inequality, NEBR working paper, No. 8904.

Sen, A., 1997. On Economic Inequality, (Expanded edition), Clarendon Press, Oxford.

SIS, 1990. 1987 Hanehalkı Gelir ve Tüketim Harcamaları Dağılımı Sonuçları, Ankara 
SIS, 1996. 1994 Hanehalkı Dağılımı Anketi Sonuçları, Ankara

Shorrocks, A. F., 1982. Inequality Decomposition by Factor Components, Econometrica 50, pages 193-211.

SPO,1976. Gelir Dağılımı 1973, Ankara

TÜSİAD, 2000. Türkiye'de Bireysel Gelir Dağılımı ve Yoksulluk-Avrupa Birliği ile Karşılaştırma., TÜSİAD yay no: 2000-12/295 İstanbul.

Wood, A. 1999. Openness and Wage Inequality in Developing Countries: The Latin American Challenge to East Asian Conventional Wisdom, Market integration, regionalism and the global economy, Eds: Baldwin, R. etal., Cambridge: Cambridge University Press, pp. 153-181.

Yeldan, E, 2001. Küreselleşme Sürecinde Türkiye Ekonomisi, İstanbul, İletişim Yayınları

Yeldan, E. 2007. Patterns of Adjustment under the Age of Finance: The Case of Turkey as a Peripheral Agent of Neoliberal Globalization., Political Economy Research Institute Working Paper Series Number 126. 


\section{APPENDIX-A: ISIC rev.3 2-digit classification and the classification of skilled and unskilled sectors}

\begin{tabular}{|c|c|c|c|}
\hline \multicolumn{2}{|r|}{ Unskilled Sectors } & \multicolumn{2}{|r|}{ Skilled Sectors } \\
\hline 15 & Manufacture of food products and beverages & 21 & Manufacture of paper and paper products \\
\hline 16 & Manufacture of tobacco products & 22 & $\begin{array}{l}\text { Publishing, printing and reproduction of } \\
\text { recorded media }\end{array}$ \\
\hline 17 & Manufacture of textiles & 23 & $\begin{array}{l}\text { Manufacture of coke, refined petroleum } \\
\text { products and nuclear fuel }\end{array}$ \\
\hline 18 & $\begin{array}{l}\text { Manufacture of wearing apparel; dressing } \\
\text { and dyeing of fur }\end{array}$ & 24 & $\begin{array}{l}\text { Manufacture of chemicals and chemical } \\
\text { products }\end{array}$ \\
\hline 19 & $\begin{array}{l}\text { Tanning and dressing of leather; } \\
\text { manufacture of luggage, handbags, saddlery, } \\
\text { harness and footwear }\end{array}$ & 29 & $\begin{array}{l}\text { Manufacture of machinery and equipment } \\
\text { n.e.c. }\end{array}$ \\
\hline 20 & $\begin{array}{l}\text { Manufacture of wood and of products of } \\
\text { wood and cork, except furniture; } \\
\text { manufacture of articles of straw and plaiting } \\
\text { materials }\end{array}$ & 30 & $\begin{array}{l}\text { Manufacture of office, accounting and } \\
\text { computing machinery }\end{array}$ \\
\hline 25 & Manufacture of rubber and plastics products & 31 & Manufacture of electrical machinery and \\
\hline 26 & $\begin{array}{l}\text { Manufacture of other non-metallic mineral } \\
\text { products }\end{array}$ & 32 & $\begin{array}{l}\text { apparatus n.e.c. } \\
\text { Manufacture of radio, television and } \\
\text { communication equipment and apparatus }\end{array}$ \\
\hline 27 & Manufacture of basic metals & 33 & $\begin{array}{l}\text { Manufacture of medical, precision and } \\
\text { optical instruments, watches and clocks }\end{array}$ \\
\hline 28 & $\begin{array}{l}\text { Manufacture of fabricated metal products, } \\
\text { except machinery and equipment }\end{array}$ & 34 & $\begin{array}{l}\text { Manufacture of motor vehicles, trailers and } \\
\text { semi-trailers }\end{array}$ \\
\hline 36 & $\begin{array}{l}\text { Manufacture of furniture; manufacturing } \\
\text { n.e.c. }\end{array}$ & 35 & Manufacture of other transport equipment \\
\hline
\end{tabular}

*The unskilled, skilled classification is done according to Landesmann, Vidovic and Ward (2004). 


\section{Appendix-B: Tests for the Panel Data Models}

\section{Model 1:}

$$
\begin{aligned}
\mathrm{WS}_{\mathrm{it}} & =\mathrm{b}_{1} \ln (\mathrm{K} / \mathrm{L})_{\mathrm{it}}+\mathrm{b}_{2} \ln (\mathrm{EXP})_{\mathrm{it}}+\mathrm{b}_{3} \ln \left(\mathrm{EXP} \_1\right)_{\mathrm{it}}+\mathrm{b}_{4} \ln (\mathrm{IMP})_{\mathrm{it}}+\mathrm{b}_{5} \ln \left(\mathrm{IMP} \_1\right)_{\mathrm{it}} \\
& +\mathrm{b}_{6} \mathrm{SIZE}_{\mathrm{it}}+\mathrm{b}_{7} \mathrm{RER}_{\mathrm{t}}+\mathrm{b}_{8} \mathrm{ENF}_{\mathrm{t}}+\mathrm{b}_{9}\left(\mathrm{ENF}_{-} 1\right)_{\mathrm{t}}+\mathrm{b}_{10} \ln (\mathrm{IVA})_{\mathrm{it}}+\mathrm{b}_{11} \ln \left(\mathrm{IVA}{ }_{-} 1\right)_{\mathrm{it}}
\end{aligned}
$$

Model 2:

$$
\begin{aligned}
\mathrm{WS}_{\mathrm{it}}= & \mathrm{b}_{1} \ln (\mathrm{K} / \mathrm{L})_{\mathrm{it}}+\mathrm{b}_{2} \ln (\mathrm{EXP})_{\mathrm{it}}+\mathrm{b}_{3} \ln \left(\mathrm{EXP}{ }_{-}\right)_{\mathrm{it}}+\mathrm{b}_{4} \ln (\mathrm{IMP})_{\mathrm{it}}+\mathrm{b}_{5} \ln \left(\mathrm{IMP} \_1\right)_{\mathrm{it}} \\
& +\mathrm{b}_{6} \mathrm{SIZE}_{\mathrm{it}}+\mathrm{b}_{7}\left(\mathrm{ENF} \_1\right)_{\mathrm{t}}+\mathrm{b}_{8} \ln \left(\mathrm{IVA} \_1\right)_{\mathrm{it}}+\mathrm{b}_{9} \mathrm{CRI}_{\mathrm{t}}
\end{aligned}
$$

For estimating the whether to choose the pooled regression or the fixed or random effects models in the models used for this study, F and Breusch-Pagan LM tests is used. For comparing the pooled regression and the fixed effects model F-test and for comparing pooled regression and random effects models Breusch-Pagan Lagrange Multiplier test is used. The tests are made for all the regressions containing all sectors and the regressions containing skilled and unskilled sectors.

1 - F-test:

$y_{i t}=\alpha_{i}+\beta x_{i t}+\varepsilon_{i t}$

$\mathrm{H}_{0}: \alpha_{1}=\alpha_{2}=\ldots \ldots=\alpha_{i}$

$\mathrm{H}_{1}$ : One of the coefficients is different

Table B.1. - F-Tests

\begin{tabular}{|l|c|c|c|c|c|c|}
\hline \multirow{2}{*}{ F-Test } & \multicolumn{2}{|c|}{ All Sectors } & \multicolumn{2}{c|}{ Skilled Sectors } & \multicolumn{2}{c|}{ Unskilled Sectors } \\
\cline { 2 - 7 } & F-value & $p$-value & F-value & p-value & F-value & $p$-value \\
\hline Model 1 & 12.70 & 0.0000 & 10.22 & 0.0000 & 12.29 & 0.0000 \\
\hline Model 2 & 9.73 & 0.0000 & 6.50 & 0.0000 & 9.01 & 0.0000 \\
\hline
\end{tabular}


2 - Breusch-Pagan LM Test:

$\mathrm{H}_{0}: \sigma_{\alpha}=0$

$\mathrm{H}_{1}: \sigma_{\alpha} \neq 0$

Table B.2. - Breusch-Pagan LM Tests

\begin{tabular}{|l|c|c|c|c|c|c|}
\hline \multirow{2}{*}{$\begin{array}{l}\text { Breusch- } \\
\text { Pagan T. }\end{array}$} & \multicolumn{2}{|c|}{ All Sectors } & \multicolumn{2}{c|}{ Skilled Sectors } & \multicolumn{2}{c|}{ Unskilled Sectors } \\
\cline { 2 - 7 } & Chi-Square Value & $\begin{array}{c}\mathrm{p}- \\
\text { value }\end{array}$ & Chi-Square Value & $\begin{array}{c}\mathrm{p}- \\
\text { value }\end{array}$ & $\begin{array}{c}\mathrm{p} \text { Chi-Square Value } \\
\text { value }\end{array}$ \\
\hline Model 1 & 254.97 & 0.0000 & 113.99 & 0.0000 & 126.83 & 0.0000 \\
\hline Model 2 & 157.99 & 0.0000 & 62.54 & 0.0000 & 56.96 & 0.0000 \\
\hline
\end{tabular}

According to the estimations of the $\mathrm{F}$ tests the null hypothesis is rejected, which means the usage of fixed effects model is better compared to the pooled regression. The Breusch-Pagan Lagrange Multiplier test also rejects the null hypothesis, which means the random effects model is better compared to the pooled regression.

For making a comparison between the reliability of the fixed effects model and the random effects model, Hausman test and Mundlak's formulation are used.

3-Hausman Test:

$\mathrm{H}_{0}$ : difference in coefficients not systematic

$\mathrm{H}_{1}$ : difference in coefficients is systematic

Table B.3. - Hausman Test

\begin{tabular}{|c|c|c|c|c|c|c|}
\hline \multirow{2}{*}{$\begin{array}{c}\text { Hausman } \\
\text { Test }\end{array}$} & \multicolumn{2}{|c|}{ All Sectors } & \multicolumn{2}{c|}{ Skilled Sectors } & \multicolumn{2}{c|}{ Unskilled Sectors } \\
\cline { 2 - 7 } & Chi-Square Value & $\begin{array}{c}\mathrm{p}- \\
\text { value }\end{array}$ & Chi-Square Value & $\begin{array}{c}\mathrm{p}- \\
\text { value }\end{array}$ & Chi-Square Value & $\begin{array}{c}\mathrm{p}- \\
\text { value }\end{array}$ \\
\hline Model 1 & 59.44 & 0.0000 & -160.98 & - & 27.87 & 0.0010 \\
\hline Model 2 & 49.93 & 0.0000 & 25.60 & 0.0012 & 24.21 & 0.0021 \\
\hline
\end{tabular}

According to the estimations of Hausman test the null hypothesis is rejected for most of the panel regressions meaning the usage of fixed effects estimator is more appropriated compared to the random effects models. For only the first model made for the skilled sectors the Chi-Square Statistic is found as negative. This calculation is an error, since chi-square is assumed to be positive. In this condition the null hypothesis could be assumed to be accepted, since the Chi-Square value is a small value. However, for estimating a more reliable result Mundlak's Formulation is used 
for making a comparison between the fixed effects model and the random effects model.

4-Mundlak's Formulation:

$y_{i t}=\mu+\beta x_{i t}+a \bar{x}_{i}+\varepsilon_{i}+u_{i t}$

$\mathrm{H}_{0}: \mathrm{a}=0$

$\mathrm{H}_{1}: \mathrm{a} \neq 0$

According to the Mundlak's formulation the null hypothesis is rejected, which means the usage of fixed effects model is more reliable compared to the usage of random effects model. Thus, by observing the results of Hausman Test and Mundlak's Formulation, it can be said that the results of the fixed effects model is more reliable for all of the regressions.

\section{Table B.4. - Mundlak's Formulation}

\begin{tabular}{|c|c|c|c|c|c|c|}
\hline \multirow{2}{*}{$\begin{array}{l}\text { Mundlak's } \\
\text { Formulation }\end{array}$} & \multicolumn{2}{|c|}{ All Sectors } & \multicolumn{2}{|c|}{ Skilled Sectors } & \multicolumn{2}{|c|}{ Unskilled Sectors } \\
\hline & Chi-Square Value & $\begin{array}{c}\mathrm{p}- \\
\text { value }\end{array}$ & Chi-Square Value & $\begin{array}{c}\mathrm{p}- \\
\text { value }\end{array}$ & Chi-Square Value & $\begin{array}{c}\mathrm{p}- \\
\text { value }\end{array}$ \\
\hline Model 1 & 41.39 & 0.0000 & 93.10 & 0.0000 & 18.63 & 0.0048 \\
\hline Model 2 & 40.31 & 0.0000 & 62.34 & 0.0000 & 22.53 & 0.0010 \\
\hline
\end{tabular}

The existence of the autocorrelation in the panel regressions is estimated by using Wooldridge test for autocorrelation.

5- Wooldridge test for autocorrelation

$\mathrm{H}_{0}$ : no first order for autocorrelation

$\mathrm{H}_{1}$ : existing autocorrelation

Table B.5. - Wooldridge Test

\begin{tabular}{|l|c|c|c|c|c|c|}
\hline \multirow{2}{*}{$\begin{array}{c}\text { Wooldridge } \\
\text { Test }\end{array}$} & \multicolumn{2}{|c|}{ All Sectors } & \multicolumn{2}{c|}{ Skilled Sectors } & \multicolumn{2}{c|}{ Unskilled Sectors } \\
\cline { 2 - 7 } & F-value & p-value & F-value & p-value & F-value & p-value \\
\hline Model 1 & 16.31 & 0.0006 & 5.73 & 0.0378 & 18.42 & 0.0016 \\
\hline Model 2 & 33.93 & 0.0000 & 11.18 & 0.0074 & 20.18 & 0.0012 \\
\hline
\end{tabular}

The Wooldridge Test shows that an autocorrelation problem is existent for all of the regressions used in this study. Hence, for solving the problem of autocorrelation AR(1) regression is used instead of classical fixed effects model. For solving the problem in the random effects models, the Prais-Winsten regression is preferred 
instead of classical random effects model. The Prais-Winsten regression reduces the disturbing effects of autocorrelation in the panel regression.

The existence of heteroskedasticity is tested by using LR test for heteroskedasticity.

6- LR test for heteroskedasticity

$\mathrm{H}_{0}$ : homoskedastic panel

$\mathrm{H}_{1}$ : heteroskedastic panel

Table B.6. - LR Test

\begin{tabular}{|l|c|c|c|c|c|c|}
\hline \multirow{2}{*}{ LR-Test } & \multicolumn{2}{|c|}{ All Sectors } & \multicolumn{2}{c|}{ Skilled Sectors } & \multicolumn{2}{c|}{ Unskilled Sectors } \\
\cline { 2 - 7 } & F-value & p-value & F-value & p-value & F-value & $p$-value \\
\hline Model 1 & 274.12 & 0.0000 & 117.41 & 0.0000 & 52.54 & 0.0000 \\
\hline Model 2 & 174.79 & 0.0000 & 84.22 & 0.0000 & 26.30 & 0.0034 \\
\hline
\end{tabular}

The LR test for the heteroskedasticity is only made for the random effects model. The tests show that a heteroskedasticity problem is available in all of the models. Thus, the Prais-Winsten regression is preferred instead of classical random effects model. The Prais-Winsten regression reduces the disturbing effects of heteroskedasticity in the panel regression. 


\section{Appendix-C: The Data}
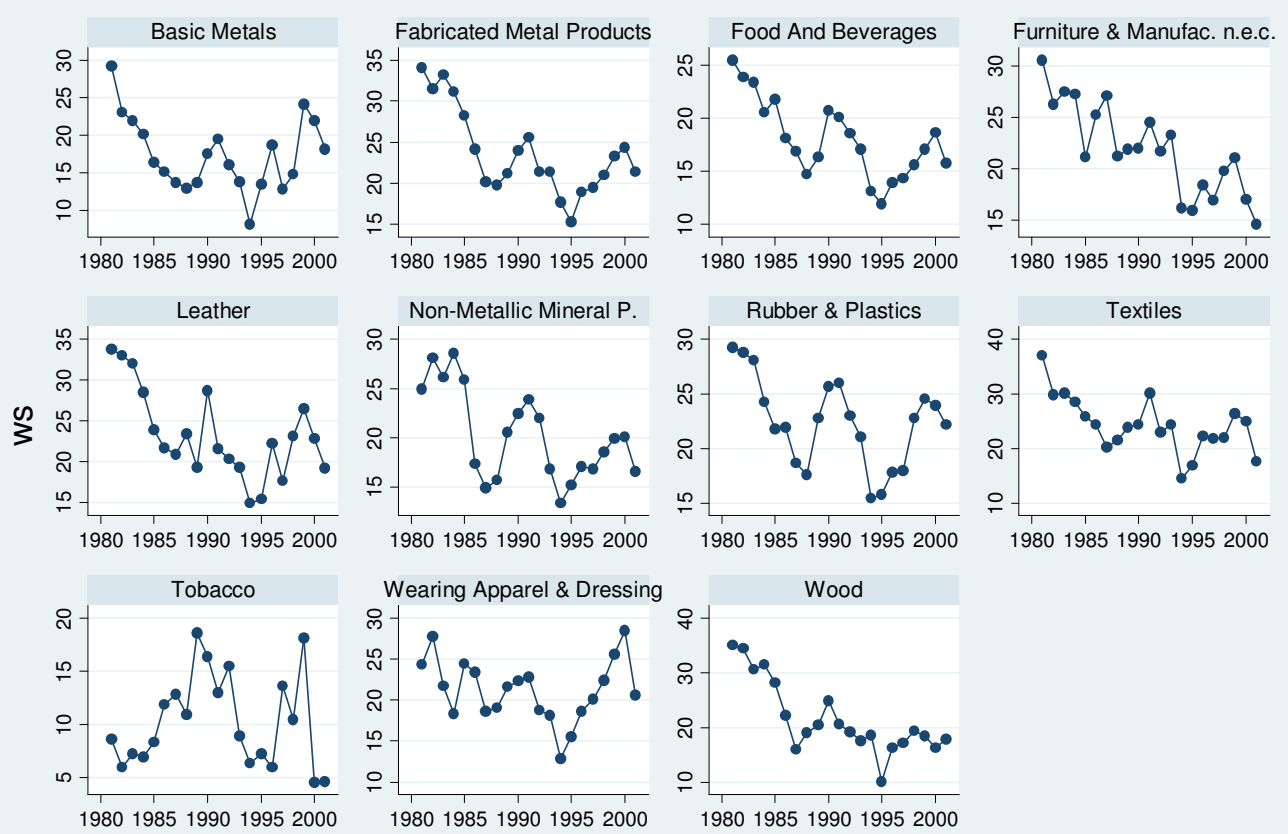

year

Graphs by sector

Figure C.1. - Change in the wage share in the unskilled sectors (1980-2001) 

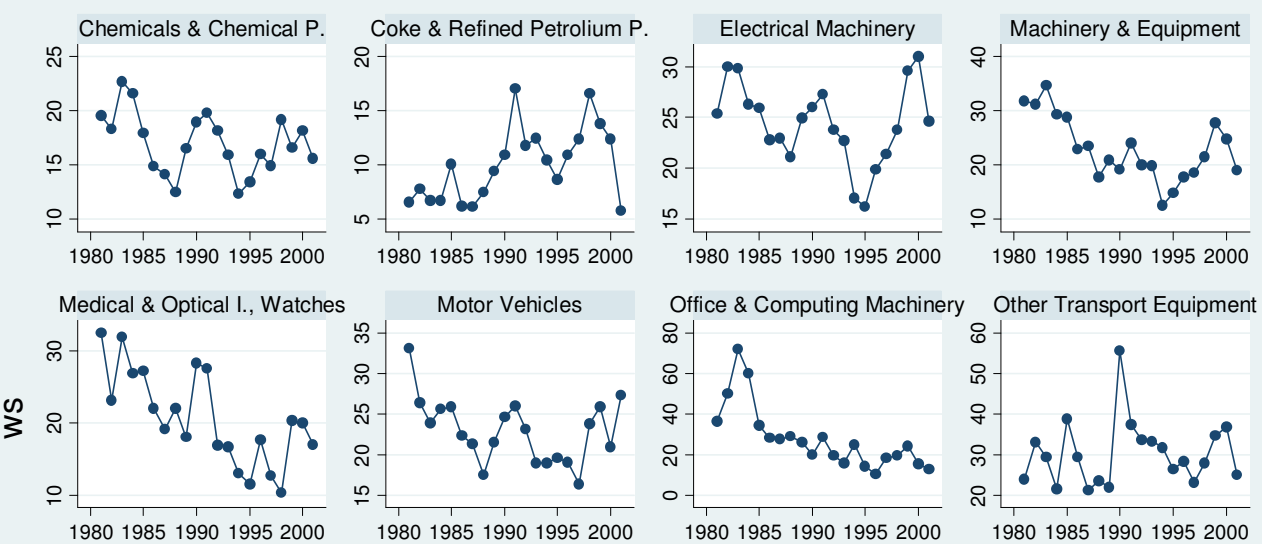

Office \& Computing Machinery Other Transport Equipment
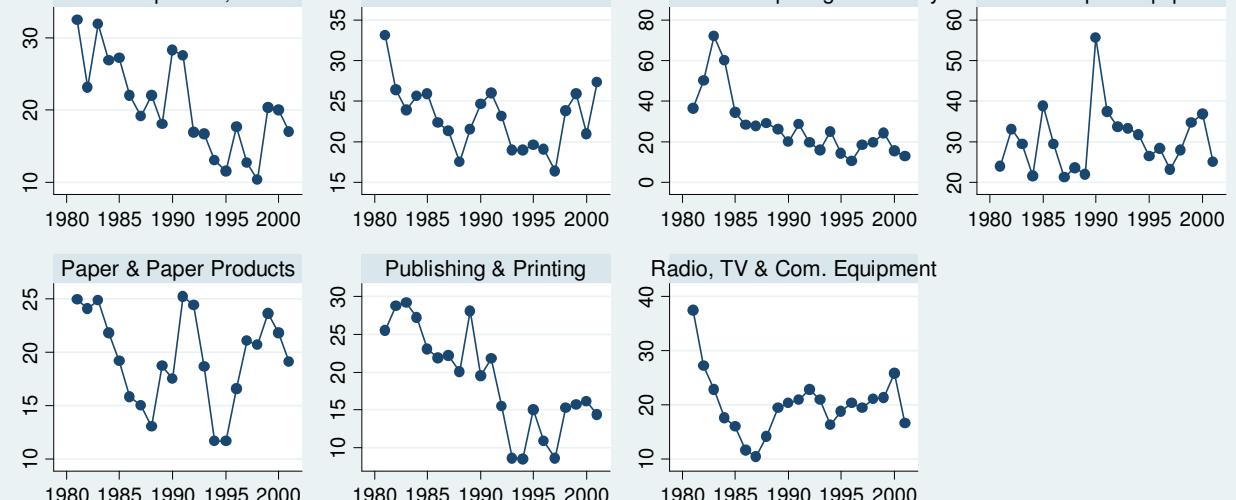

Radio, TV \& Com. Equipment

Graphs by sector

year

Figure C.2. - Change in the wage share in the skilled sectors (1980-2001) 

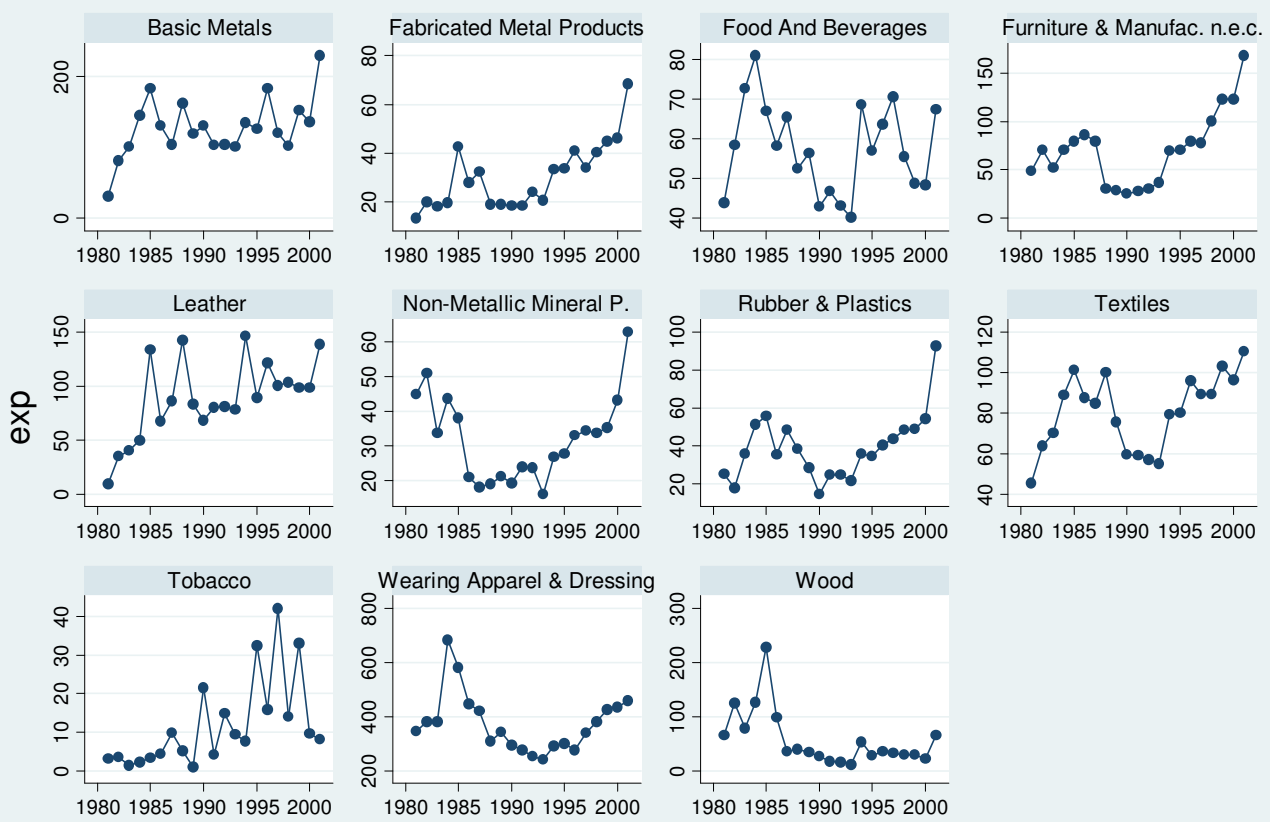

Wearing Apparel \& Dressing

Graphs by sector

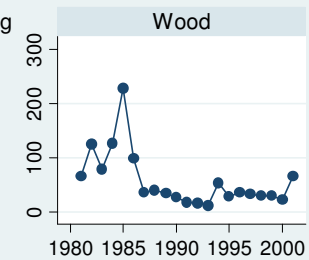

year

Figure C.3. - Change in the export/value added ratio in the unskilled sectors

(1980-2001) 


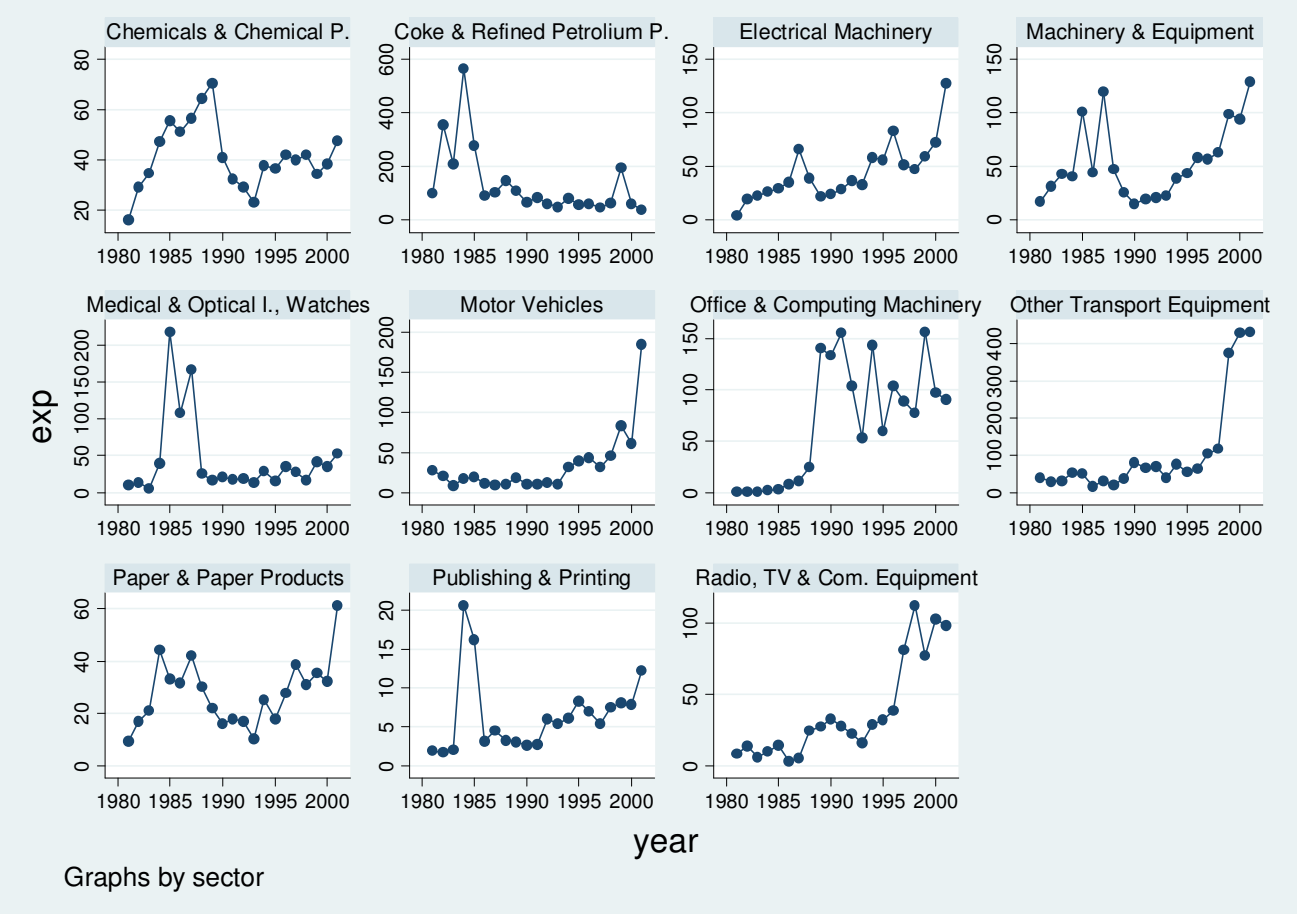

Figure C.4. - Change in the export/value added ratio in the skilled sectors

$(\mathbf{1 9 8 0 - 2 0 0 1 )}$ 

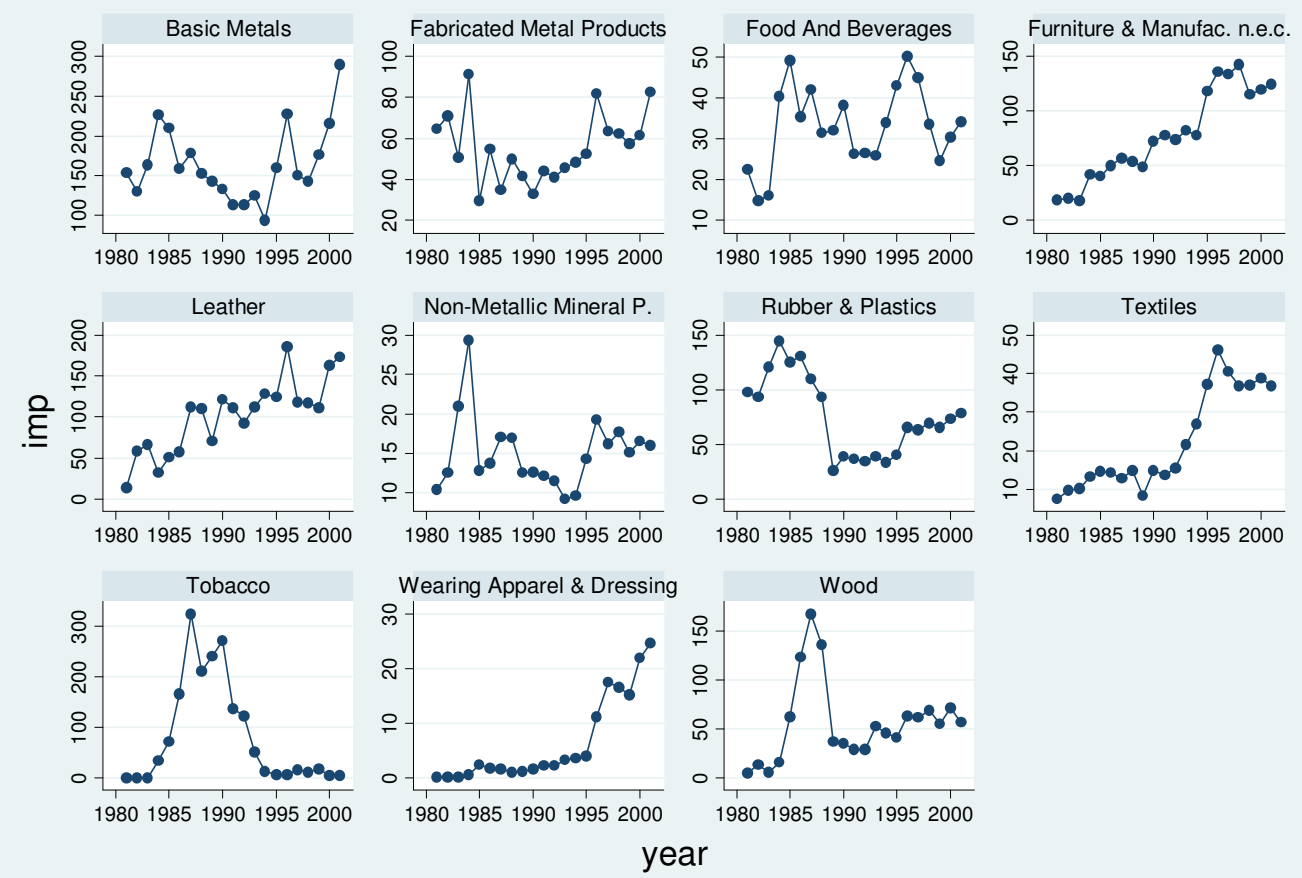

Graphs by sector

Figure C.5. - Change in the import/value added ratio in the unskilled sectors (1980-2001) 

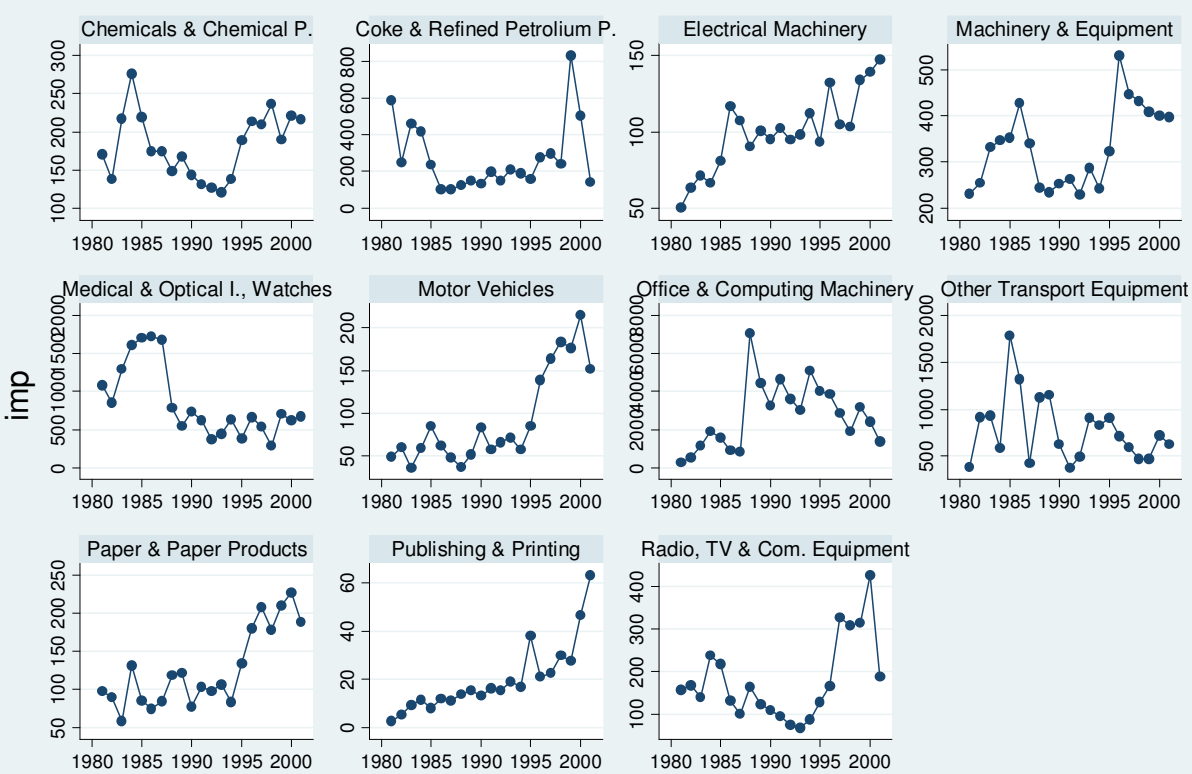

Radio, TV \& Com Equipment

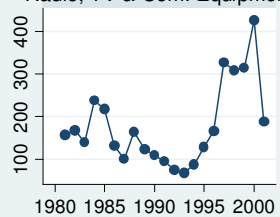

year

Graphs by sector

Figure C.6. - Change in the import/value added ratio in the skilled sectors

(1980-2001) 


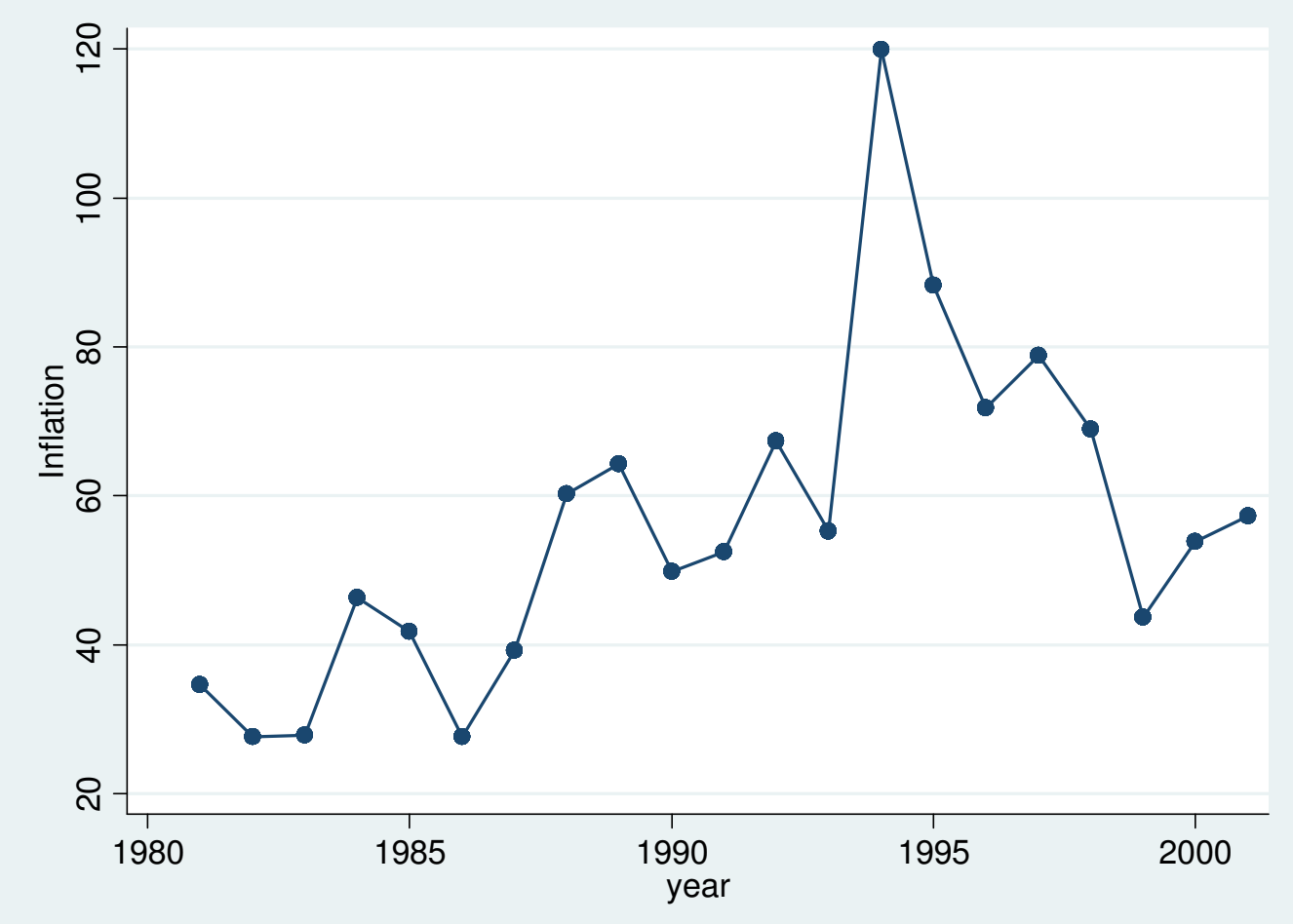

Figure C.7. - Change in the inflation (1980-2001) 


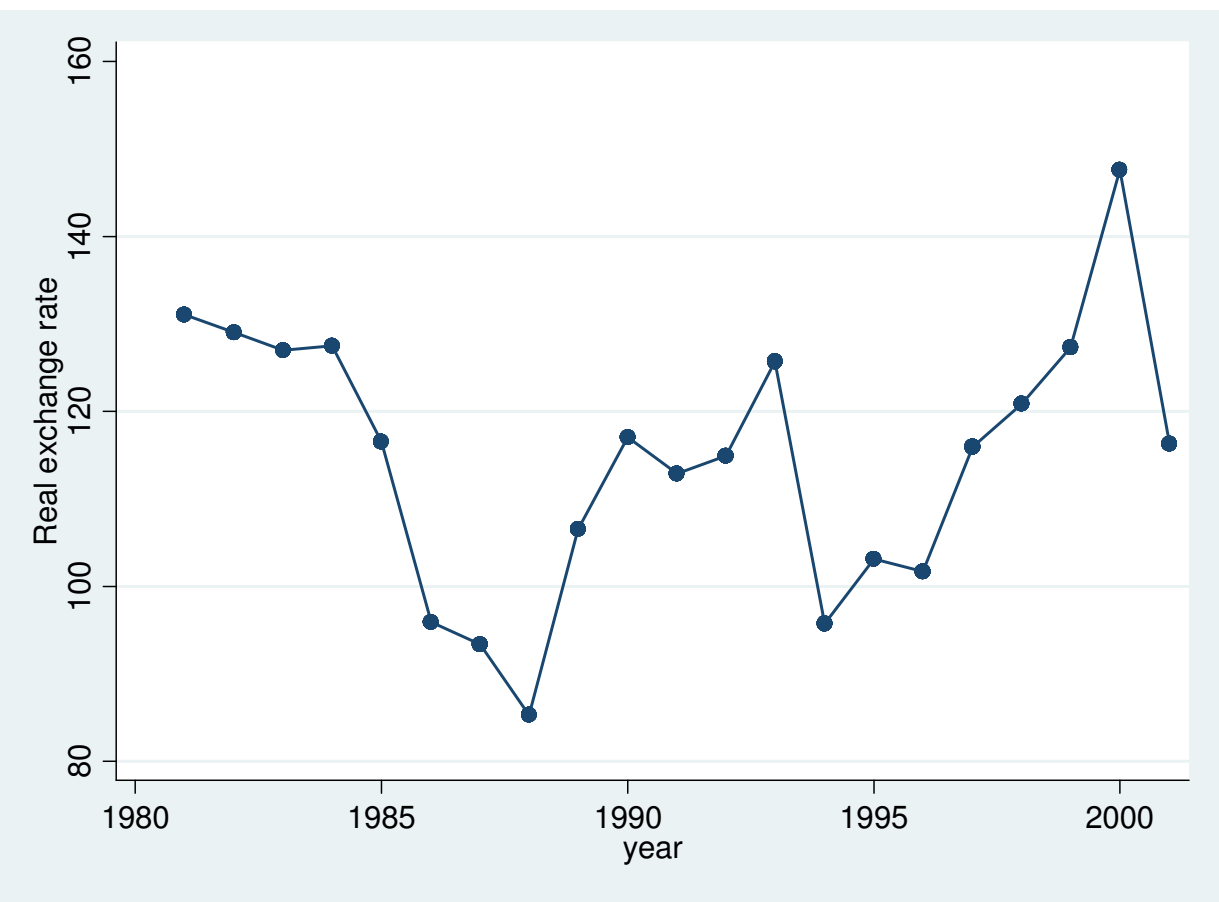

Figure C.8. - Change in the real exchange rate (1980-2001) 


\section{ABOUT THE AUTHOR}

Cem Oyvat is born in İstanbul in the year 1984. He attended Üsküdar American Academy between years 1995-2002. In 2006, he received his Bachelor of Science degree in Management Engineering from İstanbul Technical University. Since May 2007, he has been working as a research assistant at İstanbul Technical University, Department of Management Engineering, Division of Economics. 